\title{
Incidencias de las nuevas \\ tecnologías en las prácticas \\ pedagógica y productiva de \\ la comunicación audiovisual
}

Reflexiones sobre la experiencia de la

Licenciatura en Comunicación

Audiovisual de la Universidad Nacional

de La Plata - Argentina

Autor: Santiago Adolfo González

Trabajo de Investigación

Doctorado de Comunicación Audiovisual y

Publicidad

Universitat Autónoma de Barcelona

Director Dr. Nicolás Lorite García

Junio de 2004 
"Diego no conocía la mar.

El padre, Santiago Kovadloff, lo llevo a descubrirla.

Viajaron al sur.

Ella, la mar, estaba más allá de los altos médanos, esperando.

Cuando el niño y su padre alcanzaron por fin aquellas cumbres de arena, después de mucho caminar, la mar estalló ante sus ojos. $Y$

fue tanta la inmensidad de la mar, y tanto su fulgor, que el niño

quedo mudo de hermosura.

Y cuando por fin consiguió hablar, temblando, tartamudeando, pidió a su padre:

¡Ayúdame a mirar! “

de Tejidos

(Galeano, 2001:161)

Dedicado a mis hijos

A Salvador y a Sebastián 
Índice General

1. Introducción 4

1.1 La actualización de un viejo debate

1.2 Quien escribe

1.3 Un cuaderno de bitácora

2. Objeto de estudio/ objetivos / metodología 12

$2.1 \quad$ Objeto de estudio

2.1.1 Acotación del objeto de estudio

2.1.2 Análisis del objeto de estudio

2.1.3 Evaluación del Objeto de Estudio

2.2 Objetivos

$2.3 \quad$ Hipótesis

2.4 Metodología

2.4.1 Etapas

2.4.2 Técnicas de trabajo de campo

3. El escenario pedagógico institucional

\subsection{Antecedentes}

3.2 Un modelo problemático

3.2.1 Planteo del modelo problemático

3.2.2 Interpretación y Análisis del modelo problemático

3.3 El Proceso Pedagógico.

3.3.1 El funcionamiento de la cátedra de realización y lenguaje audiovisual

3.3.2 La Problemática de la Puesta en Forma

4. Marco teórico

4.1 Introducción

4.2 Los productos audiovisuales son textos audiovisuales

4.3 Conceptos sobre la producción audiovisual expresiva

4.4 La nueva imagen

4.5 Referencialidad de la imagen audiovisual 
4.5.1 La anamórfosis audiovisual

4.5.2 El modelo clásico audio-visual

4.5.3 Tarkovski y Sokurov. Dos ejemplos de tratamiento anamórfico audiovisual.

4.5.4 La relación referencial sonora.

4.6 Lo serial como esencial

4.6.1 La posproducción

4.6.2 Las herramientas en la posproducción

4.7 Un nuevo montaje. Interactividad y lectura aleatoria

4.7.1 Algunas premisas

4.7.2 El montaje en Internet

4.7.3 Los textos audiovisuales en Internet. Aproximaciones.

4.7.4 La mirada en crisis.

4.7.5 Entre la información y la transformación.

5. Aplicación del modelo Lector-Escritor audiovisual

5.1 Introducción

5.2 Aplicación del modelo lectura/escritura

5.3 El Escritor Audiovisual.

5.3.1 Los textos audiovisuales. Tipologías.

5.3.2 Resultados

5.3.3 Análisis de dos modelos audiovisuales

5.4 El Lector audiovisual

5.4.1 Determinación de un perfil de consumo mediático

5.4.2 Particularidades en el análisis de la encuesta

6.1 El Lector Audiovisual

6.2 El Escritor Audiovisual

6.3 Correspondencias entre el Escritor y el Lector Audiovisual

7.Conclusiones y Propuestas

7.1 Conclusiones

7.2 Algunas reflexiones finales a modo de propuestas para un nuevo análisis 


\section{INTRODUCCIÓN}

"Me desperté aterrorizado, el sudor frío mojaba mi frente, mis dientes castañeteaban y movimientos convulsivos sacudían mis miembros. A la pálida luz de los rayos lunares que se filtraban por entre los postigos vi, de pronto, al monstruo que había creado. Mantenía levantado el cobertor y sus ojos me miraban fijamente. Entreabrió los labios emitiendo algunos sonidos inarticulados; una mueca odiosa arrugaba sus mejillas. Quizás habló, pero tanto era mi horror que no entendí lo que decía."

De "Frankenstein o el moderno prometeo"

(Shelley, 1983:49) 


\subsection{La actualización de un viejo debate}

Las apologías y rechazos, adhesiones y paranoias que se expresan en torno a la existencia y manifestación de las nuevas tecnologías en el aula pueden ser interpretados en continuidad con los debates sobre los mass media.

Eran entonces demasiadas las incertidumbres y angustias, como así también la forma de abordarlas. Acríticos, pesimistas, apocalípticos, optimistas, críticos participativos, y críticos intervencionistas. ¿Podemos imaginar una pregunta que definiera las preocupaciones de estos últimos? Tal vez este cuestionamiento podría formularse de la siguiente manera: ¿De qué forma intervenir o participar en los medios para construir una sociedad más democrática e igualitaria?

Encontrar la respuesta a esta pregunta era obtener definiciones en torno al rol, participación e intervención de la intelectualidad en los medios. Solitario, hermoso, profético y por sobre todo muy cínico nos suena Andy Warhol con sus famosos minutos de gloria para todos aquellos que se pararan frente a una cámara de televisión.

Es así que este debate, que se había desarrollado específicamente en torno a los mass media, hoy se ha ampliado a partir del desarrollo de tecnologías (de la comunicación e información) que no solo han generado soportes, formatos y medios nuevos sino también han transformado o complementado profunda y esencialmente a los mass media en su concepción tradicional. Hoy necesariamente es eje obligado del debate temas como de qué manera han sido afectadas la producción de conocimiento, el arte, y la educación.

Sabemos que en lo referente a la pedagogía en la comunicación audiovisual no existe una tradición comparable a la desarrollada para la comunicación gráfica, visual, sonora-auditiva, gestual, u oral. Mucho de esto tiene que ver con la juventud del medio audiovisual y sus prácticas. A todo esto suman divergencia y diferencias conceptuales en el tema los distintos criterios en lo referente a la formación profesional y cultural, formas de ver la tecnología, y concepciones epistemológicas, gnoseológicas e ideológicas. 
La aparición de las nuevas tecnologías ha generado cambios profundos en el campo de la producción audiovisual. Se han desarrollado nuevas formas narrativas y escenarios comunicacionales. El uso de nuevas herramientas ha modificado procesos de guionización o concepción en la realización.

No solo los procesos de producción de textos audiovisuales se han visto afectados. El texto audiovisual en sus reformulaciones multimediales presenta como particularidades el estar conformado por distintas gramáticas, en una mixtura de textos que comparten un mismo espacio. Todo esto lo hace lenguaje de lenguajes en la medida en que se nutre de los mismos para ser nueva expresión en sí mismo.

Esta nueva gramática de los nuevos medios audiovisuales ha producido necesariamente un nuevo tipo de sujeto receptor, con novedosos parámetros de lectura. (Machado, 1997).

El uso de las herramientas informáticas y el manejo de información y redes, la aplicación de diferentes gramáticas en la experimentación de nuevos modos narrativos y/o expresivos; todos estos son aspectos que han producido y siguen produciendo cambios en los contenidos y metodologías de las asignaturas en la docencia del audiovisual.

La intención de este trabajo de investigación es analizar el impacto de las nuevas tecnologías en las prácticas pedagógicas y productivas de la comunicación audiovisual.

Es propicio para este fin el "laboratorio" que hemos elegido:

Un grupo de alumnos universitarios, aprendices del lenguaje audiovisual que realiza su primera experiencia de escritura con imágenes y sonidos. Dicho grupo es "observado y tipificado" como "lector audiovisual".

En este trabajo se intentará relacionar estos dos aspectos.

¿Qué conexiones podemos señalar entre el sujeto escritor y el sujeto lector audiovisuales? 
Asimismo con estas premisas se organiza un proceso de aprendizaje acotado a la experiencia de la enseñanza de la comunicación audiovisual desde la Facultad de Bellas Artes de la Universidad Nacional de La Plata (Argentina). Este proceso es documentado y revisado como escenario (pedagógico) y laboratorio de la investigación. 


\subsection{Quien Escribe}

Quien escribe se considera docente de imagen. Y solo en los párrafos de este apartado se tomará la libertad de escribir en primera persona.

Soy profesor de una asignatura insertada curricularmente en el primer año de la carrera de Comunicación Audiovisual de la Facultad de Bellas Artes de la Universidad Nacional de La Plata (Argentina). También soy realizador audiovisual, de hecho mi desarrollo como tal es previo a la actividad docente. Docencia y realización audiovisual son dos puntales que se completan profundamente en mi desarrollo académico-profesional. Sabemos que en general se ha considerado a los procesos de producción audiovisual como dentro del espacio de creación artística o comunicativa - informacional y comprendida su acción a una concepción en correspondencia con las formas de las industrias culturales. A partir de estas ideas se ha impedido la ampliación del campo de producción del conocimiento bajo una concepción errónea que desestima la existencia de un proceso amplio de investigación en todo proceso productivo (audiovisual). Por ejemplo todo el proceso de preproducción, grabación y posproducción de un reportaje implica la adopción de una forma de abordaje, obtención y consideración de antecedentes del o de los hechos, su registro, análisis y diagnóstico y una síntesis expresada en forma de obra audiovisual.

Es así que también siempre sentí que mi poca experiencia investigativa, no lo era tanto y que cada acercamiento a la realidad con una cámara de video o de cine era una producción de conocimiento (transdisciplinaria), y no (solo) una instrumentalización de distintos saberes. De esta manera docencia, realización e investigación audiovisual delineaban con bastante aproximación mis actividades, y en los tres campos había una preocupación y ocupación constante: El lenguaje audiovisual, la producción audiovisual.

Llevar adelante el proyecto de completar mi formación realizando estudios de doctorado implicó suspender estas actividades para ser alumno. Con verdadero 
agrado volví a experimentar una relación alumno y docente plena: es así que nuevamente sentía (esta vez en el lugar de aprendiz) aquel feedback que se producía con mis alumnos.

La interlocución, el interaprendizaje, sostenidos en un esquema de mediación pedagógica volvía a gratificarme en muchas de las nuevas experiencias pedagógicas del primer año del doctorado.

En particular encontré un espacio fecundo para continuar reflexionando sobre algunas de las pesquisas que venía realizando en mi país, en mi ciudad, en mi universidad, en mi curso, con mis alumnos.

Hacia 3 años que venía recabando información básica sobre las prácticas pedagógicas y productivas de la comunicación audiovisual en el ámbito universitario. Las más jugosas aproximaciones surgían de ahí donde más profundamente comprometido me hallaba como observador, como docente y realizador de imagen. En este sentido realizar el curso Imágenes y sonidos de la realidad (Doctorado Comunicación Audiovisual y Publicidad, Universidad Autónoma de Barcelona, Prof. Dr. Lorite, 2002) fue encontrar y reconocer una metodología de observación de la realidad. No era posible, para mi, escindir el escenario, ni a los actores del hecho pedagógico.

La observación requería de la participación del observador; lo estudiado, lo explorado, producía datos en un proceso reflexivo con quien lo investigaba. 


\subsection{Un cuaderno de bitácora}

Esta investigación es (entre otras cosas) una memoria, un cuaderno de bitácora de esa experiencia. Documentada en ciertos hechos puntuales como son un sistema de encuestas estructuradas y entrevistas informales a mis alumnos, la evaluación de una serie de reuniones multisectoriales (alumnos y docentes) con fines de gestionar una reforma del plan de estudios en vigencia, la clasificación en lo formal de las experiencias realizativas audiovisuales, y algunas aproximaciones a diversas experiencias pedagógicas novedosas o de formación y capacitación docente en el área.

Tal vez lo presentado peque de demasiado ambicioso, sin embargo el factor común está claro: la complejidad del fenómeno de la incidencia de las nuevas tecnologías en la enseñanza de la comunicación-arte se plantea en la integralidad del acto pedagógico en sí: vale la pena explorar como han sido afectadas estas relaciones en su totalidad. Son bastante particulares las reflexiones que se pueden realizar sobre la influencias de las tecnologías en las formas de producir un cortometraje, en como afecta el producto final en sus características expresivas, pero podemos ampliar y enriquecer nuestras conclusiones si no las aislamos de las peculiaridades de quien escribió el guión, de quien resolvió una propuesta estética en relación con sus características como consumidor de imágenes (visuales y sonoras). Algunas de estas cuestiones fueron delineando un sinuoso, tal vez anárquico, pero no por esto improductivo, camino de reflexión.

Es así que en la construcción del Objeto de Estudio de la investigación fueron de utilidad las siguientes preguntas:

¿Cuales son las influencias que se producen en la sensibilidad en el momento de la escritura audiovisual por la modificación de las herramientas involucradas en la totalidad del proceso productivo audiovisual?

¿Cuáles serian estas modificaciones por efecto de los hábitos de consumo mediático? 
¿Cómo separar las modificaciones que ha sufrido la acción educativa en sí, la forma de impartir conocimientos con la disponibilidad de nuevas herramientas, de los resultados de esta acción educativa en el objeto-proceso final que es evaluado?

¿Y que sucede con las limitaciones en la disponibilidad de las nuevas tecnologías, (fenómeno mas que frecuente en el ámbito educativo investigado)?

¿Se puede prescindir en nuestro análisis de las consecuencias de esta escasez, que propone, para su superación (esto es como mero ejercicio resolutivo en la práctica productiva), soluciones que se erigen en verdaderas formas nuevas, estéticas y comunicacionales? 
-2 -

OBJETO DE ESTUDIO, OBJETIVOS, HIPOTESIS, METODOLOGIA 


\subsection{Objeto de Estudio}

\subsubsection{Acotación del objeto de estudio}

Para la delimitación y acotación de nuestro objeto de estudio sobre la incidencia los procedimientos se encaminaron con fines de definir un particular escritorlector audiovisual. En esta etapa se caracterizó las distintas unidades de análisis que definen el objeto de estudio problematizando al mismo a través de su forma, dinámica, operatividad, e interrelaciones.

Fue entonces necesario caracterizar este lector-escritor audiovisual y se hizo a partir de:

- Investigar los procesos de construcción de textos audiovisuales en un sistema universitario particular.

- Caracterizar la formación del imaginario individual y grupal en una experiencia pedagógica universitaria.

- Detectar, y tipificar el uso de las nuevas tecnologías en las producciones audiovisuales pertenecientes a dichas experiencias.

\subsubsection{Análisis del objeto de estudio}

En el proceso de analizar el objeto de estudio delimitado se aplicaron los siguientes modelos de interpretación:

- "Práctica de escritura y práctica de lectura de imágenes" en el estudiante de comunicación audiovisual.

- Estructura bipolar de productor-consumidor de imágenes (a nivel individual y grupal) que señala y determina la existencia de imaginarios previos que dinamizan sus características en el proceso pedagógico.

\subsubsection{Evaluación del Objeto de Estudio:}


Fueron observados un grupo de 153 estudiantes de comunicación audiovisual. Dichos alumnos realizaron una serie de textos audiovisuales.

Los textos audiovisuales (los primeros escritos de los alumnos) son vistos como pivote donde se articulan las siguientes prácticas:

- Práctica realizativa audiovisual.

- Práctica pedagógica audiovisual.

Estas prácticas se realizan, se concretan, y tienen como objeto final una serie de textos:

- Textos audiovisuales (material audiovisual de análisis) que son "leídos", comentados, interpretados, revisada su estructura, etc.

- Textos audiovisuales (material audiovisual producido por los alumnos) que son "escritos" y luego discutidos, revisados, problematizados y finalmente evaluados y calificados.

- Y también textos audiovisuales que han sido "leídos y asimilados" con distintas y particulares (personales) formas y que conforman ese perfil de lector (nunca analfabeto) audiovisual.

La producción total de los mismos fue de 37 cortometrajes de ficción realizados en video. Las pautas y consignas para la ejercitación productiva audiovisual fueron los bastantes amplias como para permitir incrustaciones de tipo documental-testimonial o de género, permitiendo también distintas estructuras narrativas y formales estéticas (televisiva, cinematográfica, experimental, vídeo clip).

Se realizó entonces la observación de estos alumnos con la aplicación de un modelo de interpretación lectura-escritura de imágenes. El modelo puede ser sintetizado según el diagrama del gráfico 1. 
Gráfico 1 - modelo escritor-lector imágenes

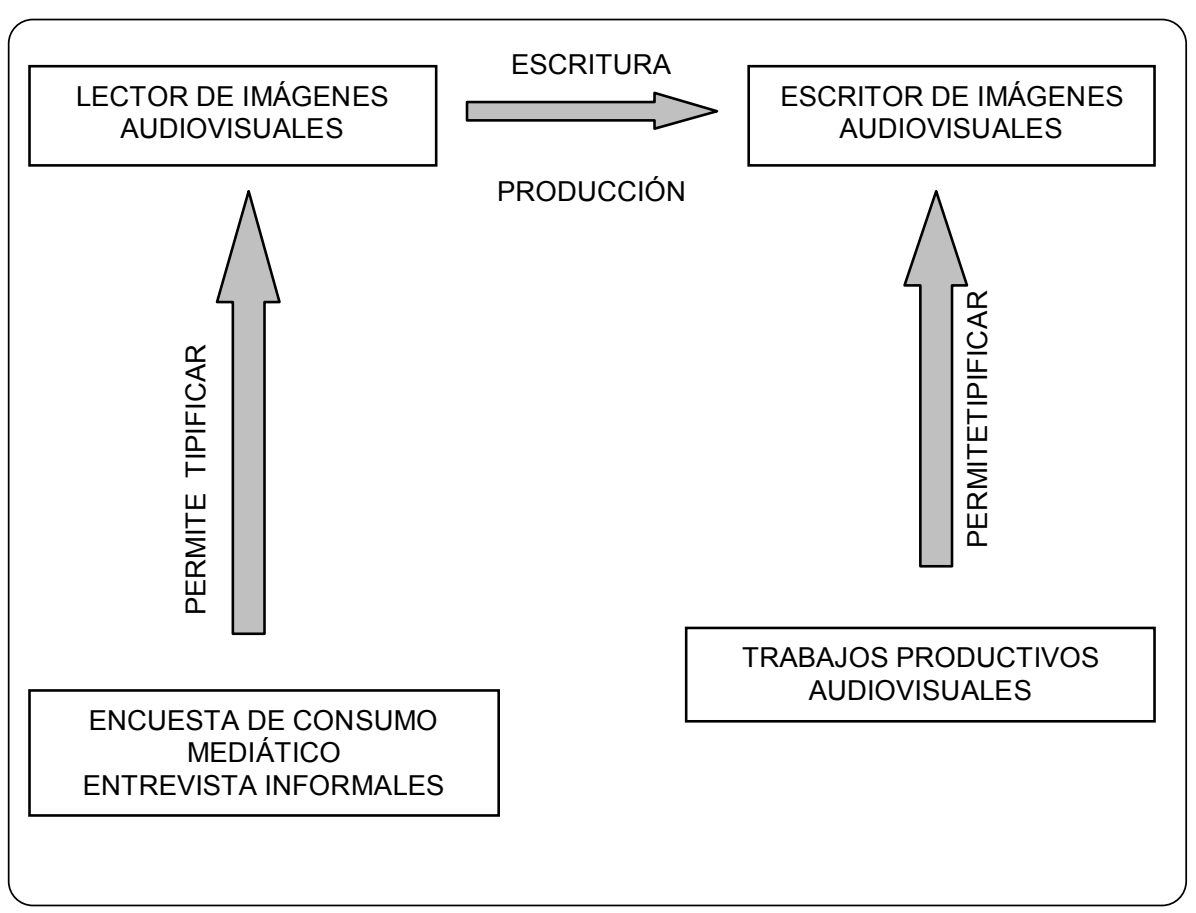




\subsection{Objetivos}

Los objetivos principales de este trabajo de investigación sobre la incidencia de las nuevas tecnologías en las prácticas de la comunicación audiovisual apuntan a diseñar un primer marco teórico-conceptual a partir de:

- Analizar dicha incidencia en las prácticas pedagógica y productiva de la comunicación audiovisual.

- Explorar una experiencia pedagógica de lo audiovisual desde el sistema universitario

- Conceptualizar dichas experiencias desde su propio desarrollo ideológico, y reconocimiento epistemológico.

- Investigar el uso social de los lenguajes audiovisuales y sus reformulaciones por causa de las innovaciones tecnológicas. 


\subsection{Hipótesis}

La investigación fue desarrollada con el carácter de exploratoria, esto es sin hipótesis fundamentales planteadas de antemano. Nuestro criterio respondió fundamentalmente a no condicionar o tener una "imagen preconcebida" o acabada del proceso y objeto a observar. La premisa central fue "entrar en el campo sin hipótesis o preconceptos" (Taylor y Bogdan, 1994).

No obstante sabemos que la forma mas usual de presentación de un texto que intenta dar informe de un proceso investigativo es contrario al "devenir que el investigador generalmente lleva a cabo" y es así que lo que se fue delineando en el proceso mismo de observación estamos aquí obligados a reseñarlo previamente. (Medawar, 1963). Según Ibáñez:

"Para todos los rendimientos de cuentas, contar la historia hacia atrás es conveniente y ahorra tiempo. Pero entender que la historia fue vivida hacia atrás puede ser extremadamente mistificador" (Ibáñez, 1998:83).

Es importante para nosotros dejar claro estos conceptos que definen y conceptualizan la forma de abordar nuestro objeto de estudio, el proceso fue observado e interpretado no con el ánimo de corroboración, lo que aquí se presenta como hipótesis fue aquello que la misma realidad nos fue develando en la observación según el modelo interpretativo Lector-escritor audiovisual. Este modelo nos permitió detectar el siguiente planteamiento hipotético:

La existencia de nuevas herramientas involucradas en el proceso de escritura audiovisual determinan nuevas operatorias que influyen en forma directa en la escritura misma, y por ende en su producto, esto es en los textos audiovisuales. Asimismo los hábitos de consumo audiovisual, entendidos como lectura audiovisual influirían en la determinación de un imaginario previo. Las preferencias en la lectura audiovisual estarían también condicionando las elecciones de forma a la hora de escribir audiovisualmente. 


\subsection{Metodología}

\subsubsection{Etapas}

El criterio metodológico se articuló en tres etapas:

\section{Interpretación del Producto Objeto audiovisual}

En esta primera etapa se definió una parrilla de análisis conceptual de los distintos parámetros que intervienen formalmente en un texto audiovisual.

Se sometió la producción audiovisual muestreada al análisis de dicha parrilla para su identificación con una categoría o tipología de lenguaje audiovisual en correspondencia con cada grupo.

\section{Interpretación del Producto Proceso-formativo}

La segunda parte de nuestro estudio se centró en revisar la metodología, (en correspondencia con objetivos y contenidos) de la propuesta pedagógica y su dinámica e interrelaciones con el producto objeto audiovisual.

\section{Aplicación del modelo Lectura/Escritura}

Posteriormente y en una tercera etapa se determinaron condiciones previas de consumo y preferencias audiovisuales de cada uno de los integrantes de cada grupo. Así se exploraron y tipificaron las existencias de distintos imaginarios individuales previos.

La tarea de tipificar a partir de encuestas de carácter individual un ideal consumidor de imágenes audiovisual de tipo grupal llevó a implementar un criterio para la evaluación y determinación de dicha extrapolación. Dicho criterio se expone y detalla en el anexo metodológico.

Posteriormente se contrastó dichos resultados con los obtenidos en los textos audiovisuales, aplicando de este modo el modelo interpretativo lector-escritor. 


\subsubsection{Técnicas de trabajo de campo}

La técnica de trabajo de campo que definió las maneras de observar y obtener datos se pueden resumir según el siguiente esquema:

Exploración $\longrightarrow$ corroboración/comprobación confrontación

Las formas de observar se pueden resumir según dos modos básicos:

- La observación participante (entrevistas estructuradas, entrevistas informales, encuestas, registros de personas) no solo fue una herramienta de obtención de información sino, además de producción de datos, en virtud de un proceso reflexivo entre los sujetos estudiados y el sujeto cognoscente, la observación participante es, en sí misma, un proceso de conocimiento simultáneo.

- Fue fundamental la observación diferida de registros gráficos, magnetofónicos y audiovisuales, como así también la recolección de archivos y antecedentes históricos.

Los espacios planteados para la indagación y aplicación de los modelos interpretativos fueron básicamente dos:

- La cátedra de Realización y Lenguaje Audiovisual en particular y la carrera Comunicación Audiovisual de la Universidad Nacional de La Plata en general. La actividad se centró en lo relacionado con la práctica pedagógica audiovisual.

- La reflexión sobre procesos productivos particulares (con mayor grado de desarrollo a nivel expresivo y lingüístico) que implicasen el uso de nuevas tecnologías con conciencia para construir nuevos códigos, modos de representación, formas de expresión, etc. El desarrollo de un hipertexto pedagógico y la elaboración de material audiovisual de experimentación, permitieron el acercamiento al uso de las nuevas 
tecnologías para la reflexión sobre la implicación directa de las herramientas en la producción.

Lo anteriormente expuesto puede ser sintetizado según el diagrama del gráfico 2. Se observa en el mismo el particular lugar del observador. Las prácticas pedagógicas y productivas audiovisuales son observadas fundamentalmente en el marco de un determinado trabajo pedagógico audiovisual desarrollado en el ámbito institucional de la licenciatura de comunicación audiovisual de la Universidad Nacional de La Plata. Estas experiencias observadas fueron ampliadas con otras experiencias externas a dicho ámbito institucional. 
Gráfico 2 - posicionamiento del observador en la pesquisa

ÁMBITO UNIVERSITARIO

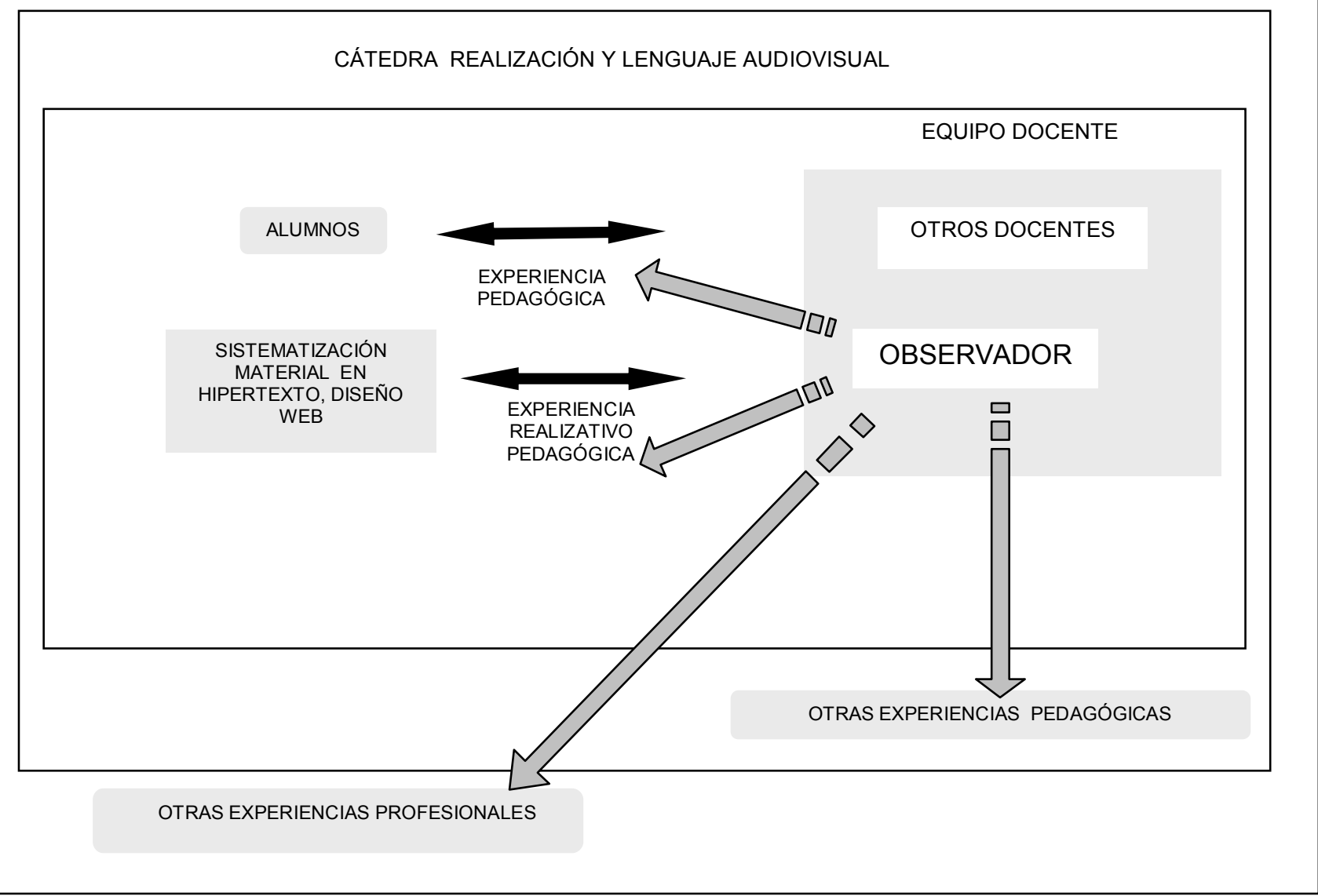


$-3-$

\section{EL ESCENARIO PEDAGÓGICO INSTITUCIONAL}

“...es fundamental para la comprensión del proceso de investigación, (...), la comprensión de la naturaleza de su producto; de la función de sus procedimientos y de las condiciones de realización en que transcurre."

de "Elementos para una teoría de investigación científica"

(Samaja, 1995:13) 


\subsection{Antecedentes}

Antes que nada es importante desarrollar una descripción de las "condiciones de realización" en que transcurre nuestra pesquisa, esto es: el escenario en el cual se haya enmarcado nuestro objeto de estudio. (Samaja, 1995).

Son importantes sus características: tales como contexto y contingencias histórico institucionales, perfil de la carrera y del egresado (de Comunicación Audiovisual de la UNLP), como así también los desajustes y correspondencias en lo referente al plan de estudios propiamente dicho y su implementación real.

Cerrada durante la última dictadura militar, la antigua licenciatura en Cinematografía de la Universidad Nacional de La Plata fue la última de las carreras reabiertas con el retorno de la democracia. Declarada "desaparecida" por las "Madres de Plaza de Mayo" su cierre fue parte de la estrategia de vaciamiento ideológico sistemático de la universidad en Argentina llevada a cabo por el gobierno de facto. Las licenciaturas en sociología, antropología, y psicología dejaron también de dictarse durante un período más o menos coincidente. Las características y especificidad de la enseñanza de la cinematografía hicieron que su recuperación fuera posterior: La gestión en pos de su restitución se inicia oficialmente en mayo de 1984 a través de una nota elevada al entonces Rector Normalizador:

"...la importancia de esta reapertura es necesaria por intereses que hacen a nuestra cultura. La dimensión de la comunicación social a través de medios contemporáneos en sus diversas manifestaciones... no se trata de una simple reapertura sino de la inclusión de esta especialidad en un marco de integración con las otras disciplinas que en esta casa (facultad de Bellas Artes de la UNLP) se estudian y que también tienen necesidades de actualización... la comunicación gráfica, la plástica, la escenografía, el cine, la TV, la música que por una situación especial se encuentran reunidas en esta facultad, es un hecho que debe ser aprovechado..." (Comisión Pro-reapertura, 1984) 
Estas ideas comenzaron a expresarse de modo práctico a través de una resolución de 1984, que autorizaba a la implementación de un Taller Experimental Audiovisual, y decía lo siguiente:

“... (se crea este espacio taller) considerando la necesidad de dar respuestas a las inquietudes de estudiantes y egresados en el conocimiento de la disciplina audiovisual y hasta tanto la universidad tome decisiones respecto de la reinclusión de la anterior carrera de Cinematografía”. (Resolución UNLP, 1984)

El Taller Experimental Audiovisual (TEAV) realizó a lo largo de su existencia de aproximadamente 10 años (1984-1994) actividades de extensión cultural, formando en los elementos básicos del lenguaje y la técnica fílmica, realizando filmes en súper ocho y 16 Mm., tales como "Diarios de Filmación”, film escuela de carácter colectivo o "Memoria y Homenaje a la noche del 16 de Septiembre de 1976", sobre el tema denominado "La Noche de los lápices" (trágico episodio de la historia de la ciudad de La Plata: la desaparición de estudiantes secundarios que reclamaban por la instauración del boleto secundario de tarifa reducida para el transporte de corta distancia).

El advenimiento del video home system (VHS), formato de video de uso doméstico, y sustituto del súper ocho en la producción de imágenes, permitió un mayor acceso a la tecnología del video. Su bajo costo modificó sustancialmente la posibilidad de producir y de hacer pedagogía de la imagen, también este fue un factor decisivo para superar las trabas económico-financieras para la implementación de la nueva carrera.

En el anteproyecto del plan de estudio de la carrera de Comunicación Audiovisual presentado ante la comisión de enseñanza del Consejo Superior de la UNLP se específica:

"...se concibe en consecuencia el perfil del futuro egresado como un producto socio artístico cultural, integrador del campo estético y comunicacional, que resuelva los problemas que la región y la nación plantean..." (Anteproyecto Lic. Comunicación Audiovisual, 1987). 
El plan de estudios de la carrera es aprobado en el mes de noviembre de 1987, sucesivos dictámenes adversos de la comisión evaluadora técnico-financiera demoran su implementación.

La reapertura se produce en el año 1993. Esto significó para el TEAV el logro de su objetivo principal y a partir de esta instancia se continuó desarrollando fundamentalmente actividades de extensión universitaria en la organización de ciclos de video y cine y de talleres abiertos a la comunidad. Los integrantes con categoría docente pasaron a formar parte del plantel de la nueva carrera. Este acomodamiento a las nuevas circunstancias institucionales planteó, en lo concerniente a la tarea docente, la posibilidad de transferir una serie de experiencias (en lo pedagógico) que ya se venían desarrollando.

El espacio que naturalmente se dio para esta continuidad fue la cátedra de Realización y Lenguaje Audiovisual.

Dicha asignatura se inserta curricularmente en el primer año de la Licenciatura y forma parte de un primer nivel de certificación (promotor audiovisual) y de formación global e introductoria. Tiene entonces un carácter formativo integral sobre los aspectos más importantes de la teoría del lenguaje y la realización audiovisual.

Algunas de las características metodológicas que guían el proceso y funcionamiento pedagógico son: integralidad teórico-práctica, de manera que las técnicas y las tecnologías son abordadas con una perspectiva de asimilación a partir de las realidades sociales concretas, la verticalidad académica es reemplazada por prácticas formativas guiadas por criterios integrativos (diferentes métodos de elaboración y prácticas grupales). 


\subsection{Un modelo problemático}

\subsubsection{Planteo del modelo}

Antes de entrar a tratar puntualmente el funcionamiento de la cátedra de Realización y Lenguaje Audiovisual nos será útil profundizar en la definición del escenario pedagógico en sus aspectos más generales.

Como una manera de comprender y delimitar el funcionamiento del Departamento de Comunicación Audiovisual se desarrolló un estudio de la gestión institucional departamental. Este estudio es fundamental para ubicar el objeto de estudio propuesto en esta investigación. Las dificultades que surgen en el funcionamiento pedagógico vinculado con las nuevas tecnologías tendrán su origen en condiciones particularidades y condiciones generales.

El estudio permite ubicarnos en una institución educativa que en sus dificultades organizativas y limitaciones de recursos (materiales y humanos) no es ajena a una realidad preponderante en el ámbito educativo universitario en Argentina.

En el marco del proceso de Reforma del Plan de Estudios de la Carrera de Comunicación Audiovisual de la UNLP se realizó tanto en el claustro docente como entre los alumnos un análisis de la situación integral del Departamento.

A partir de esta información recolectada en sucesivas reuniones de diagnóstico y con los elementos mas significativos se ensayó un modelo problemático integrado. Ver gráficos 3 y 4. 
Fueron elaborados también una serie de datos a partir de la consulta de:

- Plan de estudios vigente.

- Entrevistas informales a los alumnos.

- Entrevistas informales a los docentes.

- Análisis de las metodologías, (en correspondencia con objetivos y contenidos) de cada propuesta pedagógica (en gral. y de las asignaturas vinculadas estrecha y directamente con las nuevas tecnologías en particular) y su dinámica e interrelaciones.

- Y otros datos de campo (por ejemplo estado del espacio áulico, existencia de tecnología, etc.) 

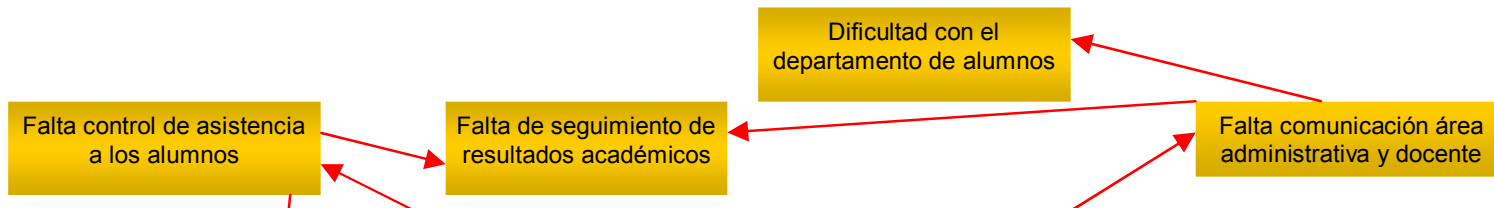

urso ingreso

inadecuado a las necesidades de la carrera
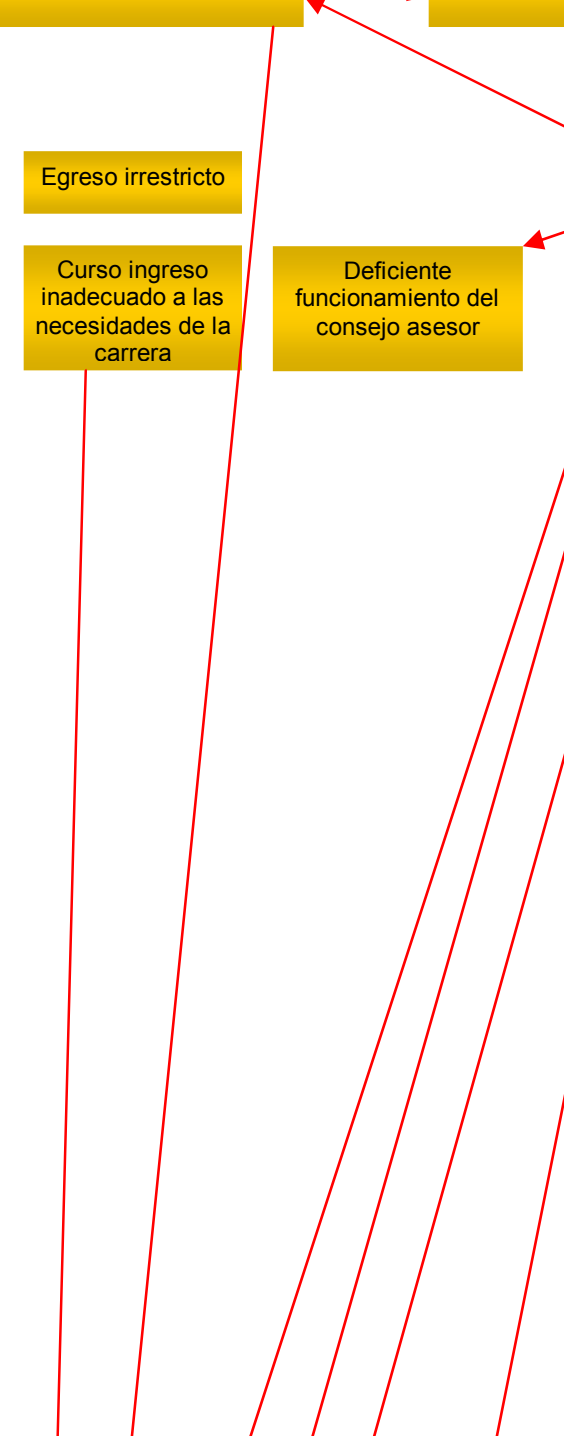
consejo asesor consejo asesor
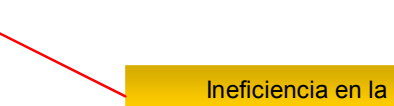
administración y organización

Falta control asistencia docente

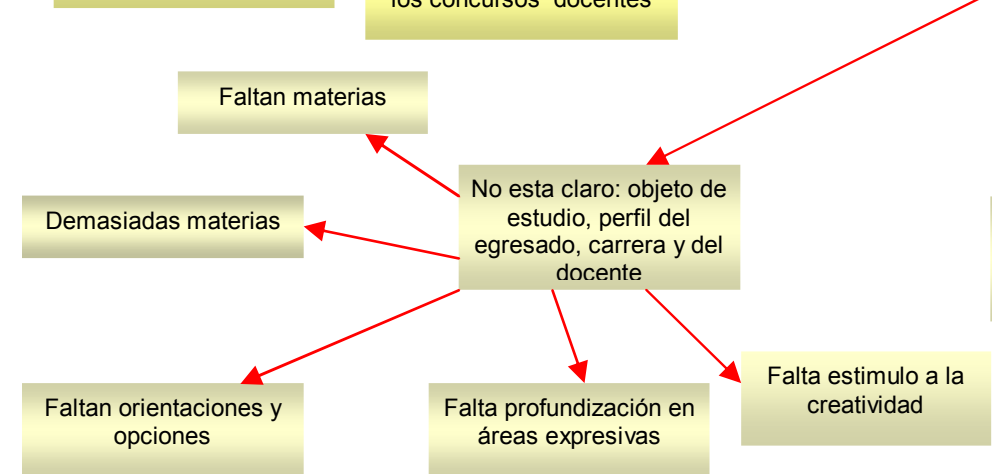

Falta estimulo a la

creatividad

Ineficiente circuito de comunicaciones entre actividades externas e internas
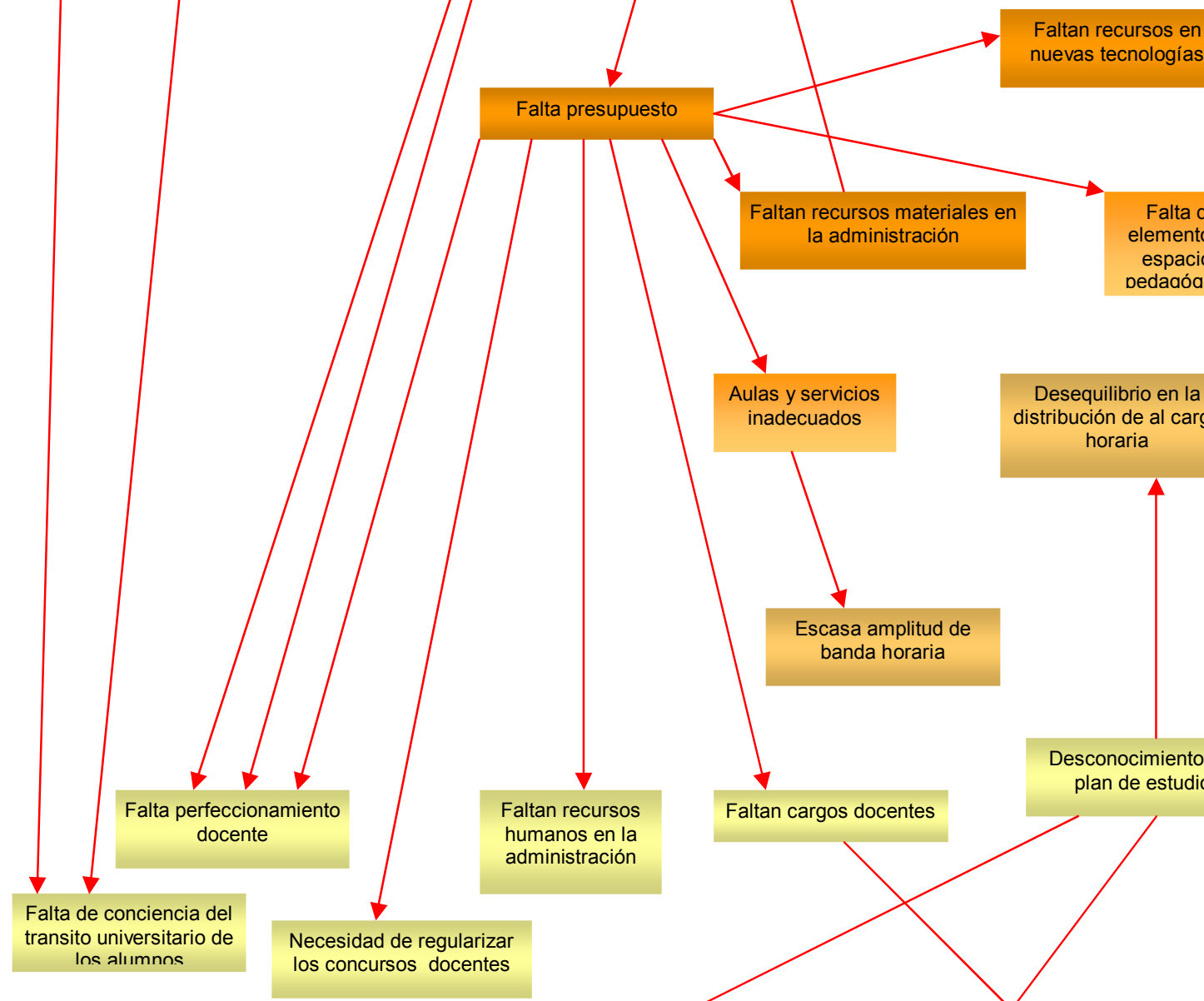


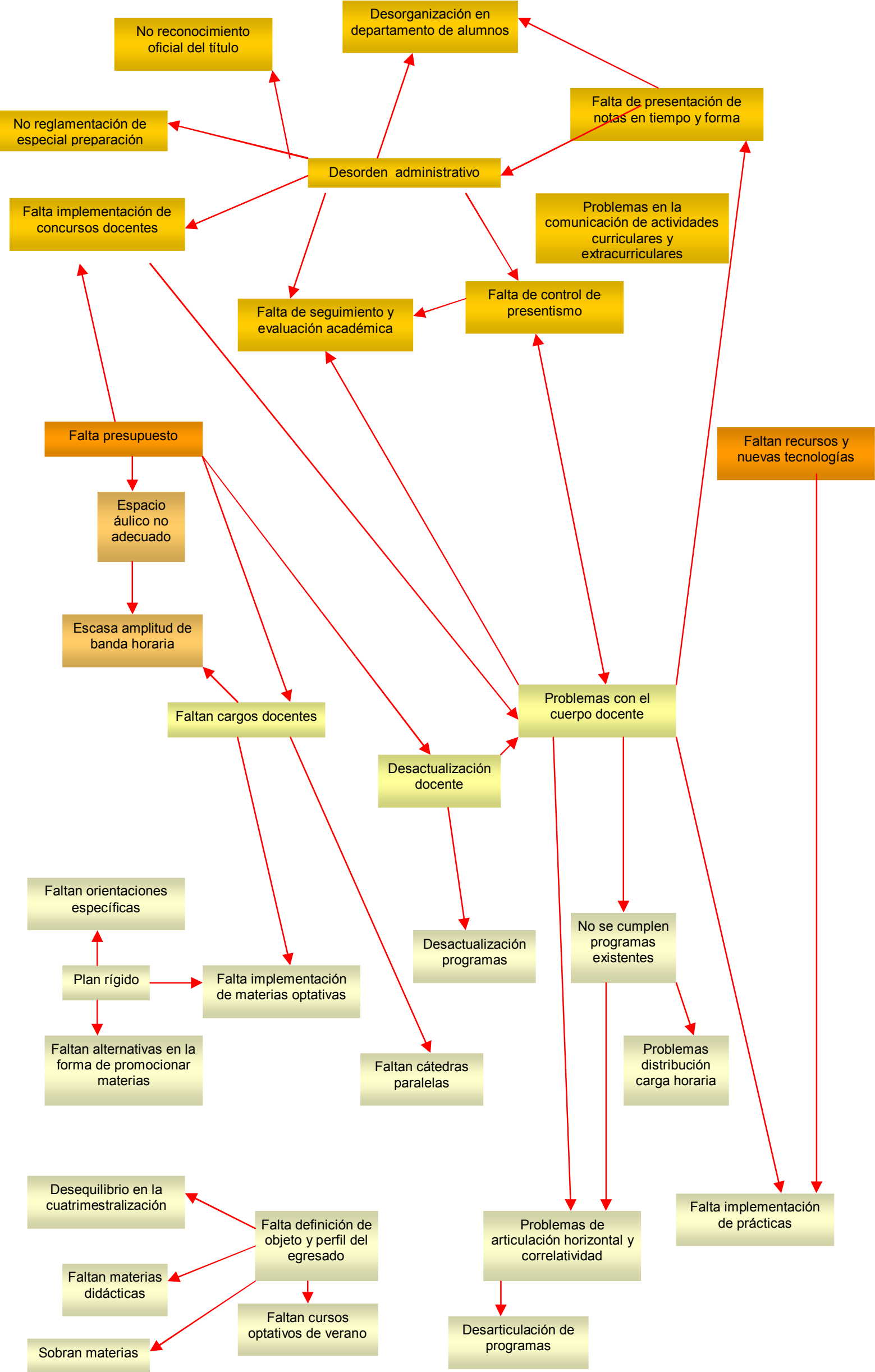


En los gráficos las relaciones causa-efecto vinculan cada uno de los problemas planteados. Se observa que el modelo problemático confeccionado supera el ámbito de los problemas (estructurales y de implementación) del plan de estudios develando serios problemas, que sin dejar algunos de estar relacionados con lo curricular, pertenecen a la esfera de la gestión y organización del departamento (en particular de sus recursos humanos y financieros).

El esquema de reestructuración identifica y agrupa los problemas según:

- gestión y organización

- recursos financieros y materiales (equipamiento e infraestructura)

- recursos espacio y tiempo

- recursos humanos

Los problemas que competen directamente al plan de estudios se agrupan según:

- problemas que surgen de deficiencias de implementación del plan vigente

- problemas del propio plan vigente

Se identifican causas y efectos señalándolos mediante una flecha vinculante. 


\subsubsection{Interpretación y Análisis del Modelo Problemático}

El modelo problemático surge de la inquietud y necesidad de reformar el plan de estudio de la carrera para la licenciatura de comunicación audiovisual de la U.N.L.P.; sin embargo según lo planteado en el mismo las dificultades del funcionamiento institucional son múltiples. La reforma del plan de estudios no modificaría los serios problemas que existen y que son generados por la desorganización y la gestión y por la deficiencia y carencias en los recursos.

Seria necesario entonces implementar cursos de acción que apuntaran a:

- mejorar condiciones en la organización y la administración

- solucionar las condiciones presupuestarias

- generar en el cuerpo docente y de alumnos las condiciones para la elaboración de una mirada compartida (en su diversidad) en lo que respecta al perfil del egresado (acordar un proyecto institucional: visión, objetivos, etc.)

Este último punto sería de importancia central para solucionar los problemas de funcionamiento en lo pedagógico, permitiría acordar un proyecto educativo de aplicación para la reforma del plan de estudio y/o ajustar los problemas de implementación del plan vigente.

En reuniones preliminares a la construcción del diagnóstico participativo, se debatió en el claustro docente sobre aspectos tales como perfil del egresado, visión e identidad del proyecto institucional educativo. Las opiniones se polarizaron entre una visión instrumentalista (enseñar los elementos e instrumentos para el hacer) y una visión de formación teórico-integral (más coincidente con el concepto gral. del plan vigente).

Entre los alumnos se observaron también divergencias. Todos consideran que son demasiadas asignaturas. Sin embargo si se analizan las distintas opiniones sobre cuales sobran o cuales faltan se observan importantes contradicciones. 
Es así que si nos centramos en el papel que las nuevas tecnologías ocupan en el debate de la reformulación del plan de estudios, se observa que tanto docentes como alumnos expresan su inquietud por la falta o escasez de recursos que afectan la renovación o adquisición de material tecnológico para la implementación de prácticas con nuevas tecnologías. La falta de presupuesto (según lo planteado en el modelo) puede ser solucionada mediante la realización de convenios con empresas. Y hasta ahí llega el planteo.

Entendemos que el problema es mucho más complejo y lo anterior es la confirmación de una visión instrumentalista. La magnitud del problema es medida solo según el grado de disponibilidad instrumental. Esto también se expresa en mayor o menor medida en las currículas. La falta de articulación intercátedra introduce importantes dificultades. Las asignaturas del área realizativa - productiva se desentienden de contener y fomentar producciones audiovisuales vinculadas con la nuevas tecnologías. Las asignaturas del área específica tecnológica se limitan a impartir los conocimientos para saber usar las herramientas. En tierra de nadie (o de todos) queda el encuentro con el lenguaje (como expresión y comunicación) en el uso de las nuevas herramientas.

Este es, a grandes rasgos, el ámbito institucional que contiene nuestro laboratorio. Teniendo presentes estas dificultades y sabiendo de la necesidad de tener que desarrollar una estrategia para abordar la enseñanza de lo audiovisual con la presencia de estas nuevas herramientas es que se implementó un criterio metodológico dentro de la cátedra de Realización y Lenguaje Audiovisual. Este criterio, en concordancia con las ideas que venimos desarrollando, tuvo como estrategia problematizar en cuestiones que tienen que ver con la realización desde una perspectiva no instrumentalista, pensando las formas audiovisuales y su relación con sus posibilidades expresivas. 


\subsection{El Proceso Pedagógico.}

\subsubsection{El funcionamiento de la cátedra de realización y lenguaje audiovisual}

Nos referiremos a la implementación del criterio metodológico pedagógico audiovisual aplicado durante los procesos de producción de los textos audiovisuales observados.

Fundamentalmente se trabajó sobre la idea de accionar sobre este instrumentalismo o fetichización tecnológica al que ya nos referimos. Según estas visiones la tecnología es un fetiche, un objeto mágico que por su sola presencia resuelve todos los problemas inherentes a la plasmación de un textoproducto audiovisual. La hipervalorización de las herramientas, de la tecnología en detrimento de los demás aspectos puestos en juego en el proceso, es la consecuencia inmediata.

Fue entonces que las palabras expresión, lenguaje audiovisual, comunicación, estilo, forma, fueron claves a la hora de pensar las consignas de trabajo.

Con esto, el planteo pedagógico audiovisual para con los alumnos fue:

- Concentrar en los problemas de lenguaje audiovisual.

- Desalentar propuestas que impliquen dificultades productivas 0 tecnológicas: plantear el ejercicio para hacer sentir al grupo el problema de todo lo que define su puesta en forma.

- "Pensar la forma". El problema del ¿que contar? se suspende, la acción pedagógica converge al encuentro del imaginario grupal. Como estrategia se propuso una serie de escritos (cuentos, poesías, ensayos etc.) como disparadores de la idea. Todo se articula en problematizar la resolución en el plano estético. Se habla de planos, de imágenes visuales y sonoras, de montaje, etc., pero todo enmarcado en el concepto de un desarrollo de estilo o producto estético. 
- Tener presente que la experiencia es un laboratorio en el funcionamiento grupal permitiendo al grupo experimentar las exigencias de la producción en las etapas de preproducción, rodaje-grabación, y posproducción. (estar atento en la elaboración de un diagnóstico para posteriores ajustes grupales)

A cada grupo realizativo se le planteó el uso de una estructura guía para la determinación de una "propuesta estética" según se pasa a detallar. 


\section{Ítems para el desarrollo de una Propuesta Estética}

\section{Puesta en plano}

En un sentido Técnico

- Tamaño de plano

- Movimientos de cámara

- Recursos (collage, efectos, etc.)

\section{En un sentido Formal}

(el diseño espacial)

- Relaciones formales al interior del cuadro

$$
\begin{array}{ll}
- & \text { Profundidad de campo } \\
- & \text { Campo, fuera de campo } \\
- & \text { Esquemas compositivos (diagramas, plantas) }
\end{array}
$$

- Relaciones formales entre planos

Unidades mínimas de análisis, por secuencia o una idea gral.

En un sentido Expresivo

\section{Puesta en escena}

En un sentido Técnico

Nombrar los objetos presentes, los elementos.

En un sentido Formal

Organización espacial escénica, la ambientación:

- Estilo de decorado

- Maquillaje

- Tipo de representación: Realista o alegórica

- Planta escenográfica

En un sentido Expresivo 


\section{lluminación}

En un sentido Técnico

- Tipo de lámparas

- Cantidad

\section{En un sentido Formal}

- Tipo de iluminación (claroscuro, valor tonal)

- Esquema de iluminación

- Efecto plástico visual

En un sentido Expresivo

Montaje

En un sentido Técnico

Recursos:

- Por corte

- Por fundido (encadenados, blanco, negro)

- Duración (estimativo por plano, secuencia y totalidad)

En un sentido Formal

Tipo de montaje

- Paralelo

- Acelerado

- Atracciones

- Invisible

- Plano secuencia

Dirección de miradas

Dirección de movimientos

Espacio-Tiempo. Su articulación.

En un sentido Expresivo

\section{Sonido}

En un sentido Técnico

- Música

- Ruidos (referir e escena visualizada/acusmático)

- Voz (diálogos, voz en off, monólogos, voces en flash-back)

En un sentido Formal

- Relación imagen-sonido

- Música (desborda, expresa, acentúa)

- Ruidos

- Voz (tono-ritmo-timbre)

En un sentido Expresivo 


\section{Acercamientos sobre el estilo.}

Todo tipo de documentación, escrita, grabada en imagen o sonido, fotografías, objetos, fuentes de periódicos y revistas, notas de pensadores, etc.

El material que se pidió como documentación de estilos posibles a desarrollar, sirvió fundamentalmente para dar marco a las reflexiones del sentido expresivo (se observará no se ha puntualizado ningún señalamiento en este ítem).

Reflexionar sobre la percepción - recepción que tuvieron cada uno de los alumnos frente a determinada forma expresiva: ¿el qué se quiere contar y como se hace tiene alguna relación con lo que expresa? Estas (pre)ocupaciones se puede visualizar en esquema del gráfico 5 .

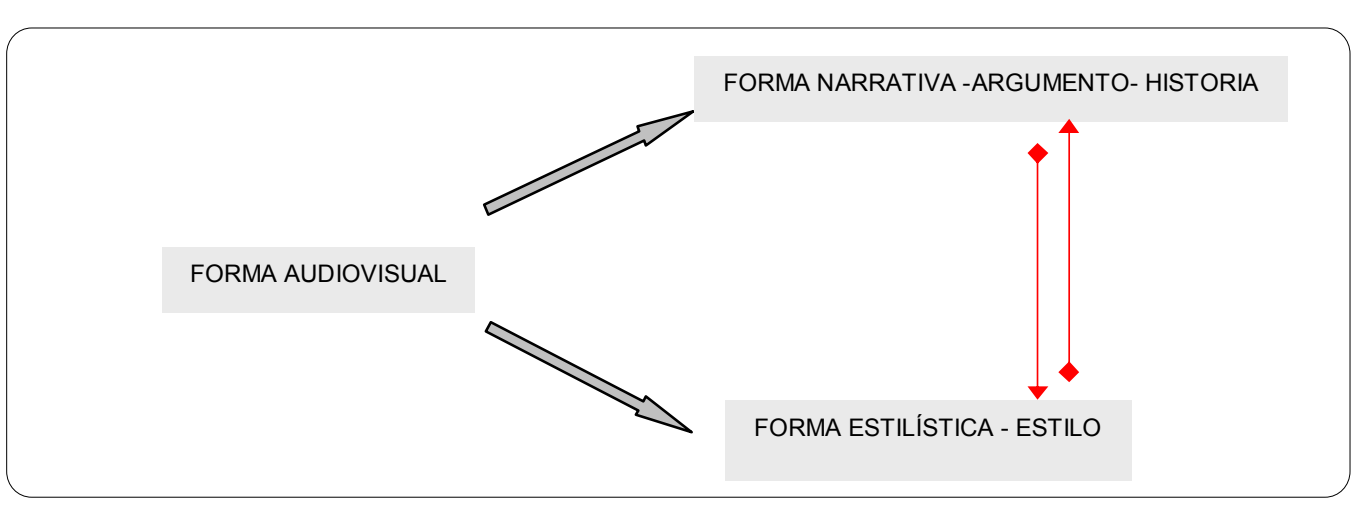

De esto surge que la narración es el proceso mediante el cual el argumento y el estilo interactúan en la acción de indicar y canalizar la construcción de la historia. La narración incluye los procesos estilísticos. 
En lo que fue la presentación de los trabajos, fueron elementos fundamentales para la evaluación de las relaciones entre el proyecto audiovisual (guión) y el acto productivo audiovisual (cortometraje terminado): la propuesta estética, una memoria de rodaje o cuaderno de bitácora y el trabajo terminado.

Con las anteriores herramientas se observó un total de 153 alumnos que agrupándose realizaron 37 cortometrajes. Estos alumnos fueron por supuesto sometidos a una mirada integradora de todo el proceso pedagógico que involucró otras prácticas realizativas y de reflexión teórico-práctica.

\subsubsection{La Problemática de la Puesta en Forma.}

El abordar la experiencia productiva enfrenta a los alumnos consciente 0 inconscientemente a la dimensión de su propio imaginario. La construcción de ese pequeño mundo propio, que es todo discurso audiovisual expresivo, exige necesariamente la definición de una lógica. Es así que en los procesos de simbolización se construyen relaciones que constituyen por sí mismas un discurso audiovisual. Discurso que siempre guarda estrecha relación con ese imaginario autoral (individual o grupal). De esta manera podemos entender este primer encuentro con los rudimentos del lenguaje audiovisual y su relación con su fuente originaria.

El dispositivo técnico-expresivo audiovisual hace que los alumnos para su puesta en forma consideren como será este sistema y que elementos lo integran, hablamos aquí de los recursos lingüísticos. Es así que en este proceso deberán considerar que forma buscan, como la presentan y representan.

Por otro lado, tutoriar este aprendizaje es responder pedagógicamente con un modelo de mediatización que acompañe la potencialidad del alumno, entendiendo que ese potencial es acto en el encuentro con su propio imaginario. 
Pero ¿como acompañar? ¿Cómo potenciar una poética? ¿Cómo confiar en los procedimientos, en las técnicas, fomentando la creatividad fundada en el imaginario propio? Evidentemente cualquier modelo que no sea el de mediación resulta inapropiado en el terreno de la educación artística.

Solo un ejemplo para graficar lo que consideramos es el lugar más delicado en la labor docente que nos compete, este es el momento de evaluación de un producto artístico/comunicacional.

Como ya hemos señalado el alumno asume el desafío de construir su propio discurso audiovisual a través de la realización de un cortometraje. Se dejan márgenes muy amplios en la definición de la realización en sí, limitando solamente el tiempo máximo y mínimo y el carácter ficcional predominante del trabajo. Quedan a definir por el grupo de realización elementos como estructura, género, estética/estilo, inserciones no ficcionales, pertenencias expresivas a un determinado medio (cine, televisión, etc.). Las consignas permiten un amplísimo terreno de resolución de lo que es para los alumnos su primera escritura con imágenes.

El momento de la evaluación de dichos trabajos se constituye en lo más fuerte del curso. No se está evaluando solo el producto (cortometraje), se revisa el proceso en su totalidad. En clase el grupo presenta su producto a la cátedra y a sus compañeros de curso y se produce un estado de debate en donde el grupo no solo expone el producto final sino también sus búsquedas, sus intenciones, sus perspectivas futuras como escritores de imágenes, su perfil como lector de imágenes. Este momento se muestra a veces (en la superficie) anárquico pero la contención del proceso permite tratar y repasar contenidos fundamentales, incorporando aquellos que surgen de la confrontación con el material expuesto. Esta instancia se puede entender como un momento de profunda objetivación a partir de la intersubjetividad puesta en juego en la diversidad de opiniones, conceptos, ideas y visiones, que se expresan en la evaluación.

".. la época actual exige reconocer la transformación que la enseñanza debe asimilar para compartir con los educandos la presencia de un mundo en el que 
las formas están signadas por el dinamismo, la información por la versatilidad y los criterios de verdad se vuelven cada vez más complejos. Ello demanda de relaciones de interlocución entre docentes y alumnos, en un proceso de aprendizaje que desarrolle en ambos el conocimiento,.." (Propuesta metodológica del plan de estudios de la carrera de Comunicación Audiovisual. FBA. UNLP, 1987:12.)

Interaprendizaje es la palabra que define lo anterior, la interlocución con la idea que siempre es posible aprender del otro (aun y sobre todo en un proceso puramente evaluativo).

Considerar procesos, recorridos, búsquedas, intenciones y logros, es el verdadero desafío a la hora de evaluar en una mediación pedagógica que parte de los intereses mutuos, promoviendo particularidades, y sabiendo acompañar búsquedas.

Como decíamos más arriba, entendiendo que el docente solo es guardián de la potencialidad del alumno y que ese potencial es acto en el encuentro con su propio imaginario y poética.

El posicionamiento del alumno frente a la propia obra, el balance de la propia experiencia, la apertura, encuentro y apropiación de discursos y poéticas, son aspectos importantísimos en el aprendizaje. El posicionamiento del docente: un discurso personalizado fomentando la interlocución, la conversación. Un involucrarse en el proceso a través de comentarios de experiencias personales reduce las distancias existentes entre quien se supone imparte los conocimientos y quien los recibe.

El uso como herramienta pedagógica del texto paralelo (como forma de objetivar documentando testimonios, vivencias, resultados de reflexiones e investigaciones), permite fijar la relación texto-contexto. El texto paralelo es una herramienta de uso cotidiano: el aspecto realizativo de la materia (realización de un cortometraje) puede ser visto como un texto paralelo (audiovisual) a los textos de teoría de lenguaje audiovisual. 
El párrafo de Eduardo Galeano citado al comienzo de este trabajo de alguna manera sintetiza la complejidad de todo hecho pedagógico (audiovisual). El mundo esta ahí, terrible a veces, hermoso otras, rodeándonos, requiriéndonos o indiferente... el mar como el mundo es infinito, inabarcable. La mirada permite dominarlo, el niño tartamudea, pide ayuda, pide mirada, pide lenguaje.

Definitivamente hoy no podemos considerar desde la docencia artística comunicacional que hay métodos o formas absolutas. Infinidad de veces hemos buscado como docentes de imagen, y en correspondencia con métodos que más tienen que ver con visiones positivistas, desligarnos de la pasión para contemplar los secretos de los mundos imaginarios que se nos presentan en una pantalla, pero difícilmente estos mundos existirían sin una pasión. Esto también es una responsabilidad docente y tal vez sea la variable más difícil de abordar.

Frente a un sistema comunicacional hegemónico el compromiso docente se basa no solo en hacer comprender las variables lingüísticas, debe ser objetivo también que los alumnos tengan como recurso básico la fuente desde donde brotan sus sentidos, promoviendo inquietudes realizativas que se consoliden en un producto audiovisual que surja de un claro punto de vista, el del propio alumno: futuro escritor de imágenes audiovisuales. 


\section{MARCO TEÓRICO}

"Por consiguiente, antes hablábamos de cine y ahora hay que hablar genéricamente (...) de audiovisual (...) la Galaxia Lumiere, que nació a finales del siglo XIX (...) se ha convertido cien años después en una densa constelación electrónica, fecundada por la galaxia Marconi, en la que figuran la televisión, el video y la imagen sintética producida por ordenador. ¿Tienen mucho en común? Todas ellas son imágenes móviles que vemos en una pantalla, que es su soporte espectacular. Constituyen por tanto un mismo lenguaje..." (Gubern, 2000:34) 


\subsection{Introducción}

Los apartados centrales de este marco teórico intentan detectar y problematizar cuestiones que se consideran claves en la producción audiovisual y que han sido afectadas por la aparición de las nuevas tecnologías.

Se abordaran primeramente (apartado "La nueva imagen") las influencias en la imagen propiamente dicha. Revisaremos en este apartado los soportes fílmicos y electromagnéticos (analógicos y digitales), sus características y su ingerencia en la aplicación de nuevas formas de representación.

En el apartado "Referencialidad de la imagen audiovisual" se puntualiza la problemática de la referencialidad de la representación audiovisual. Básicamente se desarrolla aquí la relación entre la representación y el objeto representado.

El tercer aspecto tratado, (apartado "Lo serial como esencial"), surge en la problematización de lo estrechamente ligado a las nuevas formas de posproducción o edición digital no lineal. Las formas de estructurar el espacio y el tiempo han sido afectadas. Serialidad, repetición, disgregación espacio temporal son algunas de las consecuencias.

Se observará que hasta acá los soportes sobre los que se teoriza son el cinematógrafo (fílmico-fotoquímico) y el videográfico (fílmico-electro magnético). Los procesos así analizados tienen que ver fundamentalmente con incidencias en la representación y la estructuración pero sin abandonar una característica esencial de ambos, esto es su lectura unidireccional y sin acceso aleatorio.

Para poder incorporar este aspecto hay que adentrarse en el apartado "Un nuevo montaje. Interactividad y lectura aleatoria". Es así que a partir del análisis de tres casos puntuales de ficciones audiovisuales en la red se obtienen conceptos de aplicación sobre el fenómeno de la interactividad, enlaces estructurales y lectura aleatoria. 
Se completa este marco teórico con un análisis crítico del fenómeno de interactividad relacionándolo con el concepto de mirada (apartado "La mirada en crisis. Entre la información y la transformación"). El posicionamiento del espectador lector, la construcción de un punto de vista a partir de operatorias textuales es algo que el cinematógrafo tenía teóricamente resuelto y que la interactividad reformula. 


\subsection{Los productos audiovisuales son textos audiovisuales}

El desarrollo de esta pesquisa responde a un eje conducente y es que el objeto particularmente observado a través de sus textos audiovisuales es ese estudiante de una facultad de comunicación y arte. El producto audiovisual es entonces un primer ensayo de escritura con imágenes que además de comunicacional es un producto expresivo de ficción. Es así que se optó por desarrollar un marco conceptual que contemplara estas características de protodiscurso artístico comunicacional.

Se revisan entonces distintas características de los discursos de ficción más allá del soporte (film, video, Internet) para el cual han sido desarrollados. Este "más allá" no significa obviar la relación que existe entre el soporte y el producto audiovisual en sí, sino todo lo contrario. Posicionarnos de esta manera permite establecer relaciones y conclusiones del impacto tecnológico desde una visión menos instrumentalista.

Los cambios que nos proponemos revisar son aquellos producidos a nivel del texto. ¿Con que perspectiva vamos a analizar estos textos?

Cada texto es un espacio en donde se resumen procesos complejos. Según señala Eliseo Verón:

..."un texto, como lugar de manifestación de sentido, está lejos de ser un objeto homogéneo. Todo texto es susceptible de una multiplicidad de lecturas, es un objeto plural, es el punto de pasaje de varios sistemas diferentes, heterogéneos, de determinación. En un texto... hay diferentes tipos de huellas... según el tipo de lectura que uno pretende hacer del texto... Las huellas del autor que remiten a un sistema histórico biográfico y al universo de su "obra"... Las huellas vinculadas al trabajo de lo inconsciente... Las huellas de los vínculos que mantiene el texto con las condiciones sociales bajo las cuales ha sido producido $y, \ldots$ las huellas de operaciones que permiten el acople del texto a una situación de poder, en una red de relaciones sociales determinadas.” (Verón, 1997:33) 
Las huellas de las que habla Verón son huellas que forman textura. La "textura del texto". Textura que da distintas impresiones al tacto, según la acariciemos o la frotemos con energía, según la palpemos en un sentido o en otro. Esta riqueza del texto existe gracias a un proceso de apropiación simbólica. Esta multiplicidad de lecturas es la que permite llevar a cabo procesos de mediación.

Hacerse dueño de los símbolos es un proceso esencial en la realización y en la enseñanza audiovisual y como tal está presente y problematiza estas prácticas infinidad de veces. Nos interesan los textos como un lugar de "manifestación de sentido" (Verón, 1997). Según Llorente Bilbao:

"el texto produce sus propios efectos de sentido", para el autor el "efecto poético es la capacidad que tiene un texto de no agotarse completamente, a su capacidad para generar lecturas siempre distintas". (Llorente Bilbao, 2000:437).

Revisemos el significado de la palabra sentido:

>cada una de las aptitudes que tiene el alma, de percibir las impresiones de los objetos externos,

$>$ modo particular de entender una cosa / entendimiento, razón,

$>$ modo de apreciar una dirección desde un determinado punto a otro,

$>$ razón de ser, finalidad.

El significado de la palabra sentido en sus distintas acepciones enriquece profundamente nuestro análisis. Manifestación de sentido es manifestación de nuestras impresiones sensoriales, de nuestro sentir, también manifestación de entendimiento (tanto en la lectura como en la escritura). Interesa hacia donde nos lleva, hacia donde va este texto. Por último todos estos aspectos definen implícitamente su finalidad, su razón de ser. 


\subsection{Conceptos sobre la producción audiovisual expresiva}

No podemos desentendernos del hecho de que nuestro objeto de estudio tiene como marco una facultad de arte. Ya hemos señalado que el producto audiovisual estudiado no es solo abordado como objeto comunicacional sino también como expresión.

Expresión que existe en y gracias a un objeto concreto en el que encarna. Toda expresión necesita una materia y una técnica, un procedimiento operativo que produce la transformación de esa materia. Los antiguos griegos denominaban a esto tecnes. Esto es: el conocimiento de la técnica, de la herramienta del buen artesano. Con la instalación de las nuevas tecnologías esto se ha puesto en crisis. En particular en la producción audiovisual, el reemplazo de soportes analógicos por digitales y de las formas de posproducción llamadas lineales por las no lineales, ha conllevado modificaciones profundas. Se hace necesario entonces una revisión sobre los mecanismos y procedimientos operativos en la producción estética audiovisual. Según Ravera (1988) el hacer arte es “...hacer algo bien hecho, inventando el modo de hacerlo” (Ravera, 1998).

Debemos, como dice Ravera, "inventar nuevos modos", y esa invención es trama resultante en un proceso de síntesis.

La gestación de todo proceso expresivo puede ser interpretada a partir de una dialéctica. Sin ánimo de simplificar nos podemos guiar en el análisis según los siguientes conceptos.

- Expresión-comunicación

- Intuición- razón (inspiración-planificación)

- Aplicación inferencias (pensamiento inductivo, deductivo, abductivo, analógico-metafórico) en el procedimiento operativo.

La innovación ha redistribuido y modificado estos procesos constitutivos. Y no solo esto, lo radical de estos reemplazos tecnológicos no solo renuevan los procesos en estas dialécticas sino que introducen otras nuevas asociadas a lo tecnológico. Es así que a lo anterior podemos agregar, (continuando con un esquema binario) los siguientes conceptos pares: 
- Digital - analógico.

- Óptico binario - Electromagnético

- Lineal - no lineal

- Aleatorio - no aleatorio

Estos conceptos surgen en relación directa con el soporte tecnológico, pero, como veremos, no por eso dejan de tener consecuencias directas en otros campos.

A fines de nuestra investigación no podemos dejar de relacionar lo anterior con las vastas modificaciones que se han producido en el modo de representar el espacio, el tiempo, y la misma imagen.

Las dicotomías codificación binaria digital versus codificación analógica, y aleatoriedad versus no aleatoriedad en el acceso tienen su correlato en distintas formas de representar. 


\subsection{La nueva imagen}

El enmascaramiento del referente, por medio electrónico-digitales o la inexistencia del mismo, en una representación sintética digital son procesos comunes en la producción audiovisual vinculada a la nuevas tecnologías.

No solo la experimentación audiovisual incursiona en este terreno, la publicidad, el vídeo clip, incluso el cine espectáculo en búsqueda de nuevos aires estéticos o como posibilidad de resolver referentes imposibles o muy onerosos de reconstruir o reconstituir. Según Bettetini y Colombo (1995) la historia de la expresión humana siempre se ha dividido entre dos proyectos fundamentales, por un lado una intención de:

"reproducir por medio de signos materialmente diversos del objeto el mismo objeto destinado a la representación y por el otro lado el de experimentar, (...) la posibilidad de autonomía de los signos y de los lenguajes que los estructuran, para producir significados solo de algún modo motivados por los objetos o incluso independientes de ellos.” (Bettetini, Colombo, 1995:30).

Esto que los autores señalan como extensivo a las distintas formas de expresión, en el lenguaje audiovisual adquiere la categoría de central: el vínculo de cada imagen o sonido articulados entre sí guardan un vínculo directo con su referente. Es así que cualquier imagen se plantea según dos usos extremos:

- Velar, enmascarar, mediatizar, pictorizar el registro original, el referente se traduce en una imagen fabricada, sintetizada.

- Producir una imagen sintética pura o híbrida con el concepto de mímesis de lo real.

Según señala Virilio: 
"Entramos en un nuevo régimen de visibilidad. Creo que el vídeo y la infografía son elementos esenciales de esta mutación del régimen de percepción (...) porque se han desdoblado tres elementos: la transparencia, la óptica, la luz". (Virilio, 1991:14)

Video y ordenador son para Virilio los artífices de este nuevo régimen de visibilidad. Según veremos, el video fue la tecnología que propició el enmascaramiento, la mediatización de las imágenes y el ordenador el gran hacedor de mímesis, que con el desarrollo de su potencia de cálculo avanzó desde los simples algoritmos representacionales a las poderosas imágenes hiperreales de las simulaciones.

En ambos casos se pone en crisis las tradicionales visiones de una representación de la transparencia.

Hablar de representación transparente es hablar fundamentalmente de una de las corrientes estéticas troncales de la cinematografía. Vale la pena, a esta altura, si nos interesa comprender esa nueva imagen revisar los antecedentes que en el plano teórico-práctico nos propone el cinematógrafo.

Los esfuerzos de Bazin para construir la teoría de la transparencia (cinematográfica) parten de definir la ontología de la imagen fotográfica y extenderla a las imágenes en movimiento. Entre el objeto fotografiado y la película sensible solo se encuentra una lente (que no casualmente se llama objetivo), por primera vez se elimina toda intervención subjetiva del artista. La transparencia es fundamental para Bazin, todo el dispositivo del cine debe ser transparente para poder mejor representar la ambigüedad de lo real.

"en la utilización del montaje invisible...el fraccionamiento de los planos no tiene otro objeto que analizar el suceso según la lógica material o dramática de la escena (...)." (Bazin, 1966:123)

Esquemáticamente (la teoría de la transparencia) señala como características fundamentales a cumplir por todo film que se precie de "ser cinematógrafo" lo siguiente: 
- verosimilitud del espacio representado,

- la intención y los efectos de planificación deben tener exclusivamente fines dramáticos o psicológicos,

- los cambios del punto de vista solo deben representar la realidad de una manera más eficaz.

Según Bazin es cierto que el realizador cinematográfico dispone de un margen de libertad con el que puede subrayar el sentido de la acción, pero no es más que un margen que no podría modificar la lógica formal del acontecimiento. El uso de la profundidad de campo, como alternativa a este montaje invisible, evita el direccionamiento y manipulación de la mirada del espectador.

Con la invención de la televisión y del vídeo la imagen abandona la química del celuloide y la mímesis fotográfica, para electrificarse. La información de la señal audio y de la señal de imagen se graban en la misma cinta magnética, se codifican con parámetros similares, se transmiten por cables conectores entre grabadores-reproductores de ambas señales, se emparentan en la similitud de soporte y codificación. Esta nueva relación en el campo tecnológico entre imagen visual y sonora fue comprendido fundamentalmente en el campo de la experimentación videográfica. Según señala Duguet:

"La comprensión de la técnica ha hecho posible que artistas como los Vasulka, Bill Viola T. Kuntzel o Nam Hoover hayan sabido proponernos obras nuevas (...) han trabajado con los parámetros elementales de la imagen electrónica y, en particular, han prestado atención al hecho de que la señal vídeo es de la misma naturaleza que la señal sonora (...)" (Duguet, 1991:67)

Hubo entonces una comprensión de la técnica de ciertos realizadores del video con fines de definir una forma, una estética; también esta preocupación la podemos observar en la historia de la imagen cinematográfica. Vale la pena revisar el pensar de algunos teóricos y realizadores de los orígenes de la cinematografía y relacionar estas ideas con fines de encontrar correspondencias y continuidades. 
El director francés Abel Gance sugería un entendimiento de las posibilidades expresivas de las imágenes haciendo una analogía con la música. La esperanza de una lengua universal, de un esperanto de las imágenes, se adivina como principal intención de su elección metafórica. En su pensamiento se advierte que más que intentar comprender el naciente lenguaje audiovisual, Gance se entusiasma con vaticinar para la disciplina un futuro de factor unificador de naciones y diferencias universales quedamos con la frase "música de luz' (Agel, 1968:29) (Sánchez Biosca, 1996:72) y lo proyectamos como molde analógico para la comprensión de los terrenos de la experimentación audiovisual en la era de la producción y posproducción digital de imágenes.

Otro clásico y fundador del lenguaje cinematográfico: Serge Eisenstein nos propone, extrapolando al terreno de lo fílmico la dialéctica hegeliana y en clara analogía con ciertos procedimientos de otras artes (plástica, música), el concepto de conflicto.

Según esto debemos organizar la estructura (el montaje del film) a partir de la construcción de conflictos entre fragmentos (no necesariamente planos).

“...en mi opinión, el montaje es una idea que surge de la colisión (conflicto) de planos (fragmentos) independientes, incluso opuestos uno a otro (...) Podemos anotar, como ejemplos de tipos de conflictos dentro de la forma, dentro del plano y dentro de planos antagónicos, o montaje: el conflicto gráfico, el conflicto de plano (superficies), el conflicto de volúmenes, el conflicto de espacio, el conflicto de iluminaciones, el conflicto de tiempo." (Eisenstein, 1989:105)

La casa de vidrio, proyecto fílmico inconcluso, fue para Eisenstein la posibilidad de pensar una estructura de la imagen basada en la partición de la imagen proyectada.

"la casa de vidrio es una arquitectura de cubos transparentes, como la misma cantidad de piezas de una casa, piezas donde se desarrollan simultáneamente, 
una serie de escenas diferentes e independientes, pero que están atravesadas de correspondencias y de miradas entrecruzadas..." (Bongiovani, 1996:77)

El concepto de fragmento del sistema de Eisenstein, designa una nueva unidad fílmica, unidad de discurso más que de representación. La producción de sentido surge en el encadenamiento de fragmentos sucesivos bajo el modelo de conflicto. El conflicto es para Eisenstein el modo más claro de interacción entre dos unidades cualesquiera del discurso fílmico.

Tanto a Abel Gance como a Eisenstein les importa la imagen en sí misma, el objeto que es representado pasa a segundo plano. Es así que constatamos que el cinematógrafo (conforme algunos de sus mas importantes realizadores) produce en sus orígenes y desde el silencio, música de luz. Dziga Vertov, Rene Claire, Eisenstein, hacen pentagramas, calculan proporciones y series, construyen estructuras y comparan ritmos, como lo haría un músico, un arquitecto o un matemático. Todo esto señala esta preocupación especial por la relación referente-representación que venimos señalando.

Estos planteos esencialmente estético vanguardistas que se hicieron desde el cine originario fueron progresivamente superados por un modelo que terminó respondiendo más a la claridad expositiva de una narración transparente. Sin embargo como señala Duguet (1991) el surgimiento de las imágenes electrónicas trajo aparejada una "comprensión de la técnica" puesta en juego para la producción de estas imágenes. Comprensión que retomó aquellos procedimientos y formas de ver del cine como música de luz. Es así que en la producción de imágenes por medios electrónicos el tratamiento de la señal vídeo según procesos y prácticas de tratamiento de la banda sonora es una constante. La señal vídeo es tratable (coincide en su forma de almacenamiento) con herramientas análogas a las de la señal audio. Luz y sonido se reúnen en su naturaleza ondulatoria. Este reencuentro fue festejado por realizadores experimentales del periodo analógico: modificaron la velocidad de barrido, conectaron una señal de audio en una entrada de vídeo, electrificaron la imagen 
(visual y sonora), produjeron ruidos; interferencias, defectos y perturbaciones que hicieran sentir la nueva naturaleza del medio.

Vemos entonces que el medio electrónico, el video, hizo caso omiso de este debate teórico sobre el referente (desarrollado en la cinematografía) y se planteó como problema la materialidad del soporte. Haciendo uso de técnicas expresivas disímiles, correspondientes a una u otra corriente, llegó a preguntarse sobre cuestiones superadoras de la clásica dicotomía objetorepresentación, original-copia, esencia y apariencia. Es así que el género videoarte es generalmente un buen ejemplo de organización de la realidad representada en forma no aristotélica, estructurando plástica y perceptualmente los elementos visuales y sonoros. La preocupación por la percepción es la clave. El querer "hacer ver el medio" de Paik o "hacer ver el ver" de Bill Viola (Duguet, 1991) son dos casos paradigmáticos, y ejemplificadores, en ambos casos la preocupación es la percepción.

A fines de la investigación interesa señalar cuales son entonces aquellos recursos expresivo-formales que se han manifestado en nuestros textos audiovisuales observados en correspondencia con el uso de nuevas tecnologías (ordenador o video). Lo que señalamos como una intención expresiva de "querer hacer ver el medio" tiene su manifestación bajo dos formas fundamentales: electrificación y/o pictorización de imagen por un lado e imagen sintética (pura o híbrida) con concepto mimético. A pesar de ser dos procedimientos que van en sentido contrario (mímesis-no mímesis) tienen en común que ambos se desentienden, en mayor o en menor grado, del referente, esto es del elemento, del objeto que se representa. Creación y destrucción de la representación son los dos procedimientos formales que fundan esta dicotomía. Machado en sus textos enfatiza esta importante diferenciación según la herramienta puesta en juego:

"Actualmente, computadora y vídeo, en sus modos de apropiación más usuales, corresponden a dos estéticas radicalmente diferentes que podríamos caracterizar groseramente como la de creación y la de destrucción respectivamente" (Machado, 1996:72) 


\subsection{Referencialidad de la imagen audiovisual}

\subsubsection{La anamorfosis audiovisual}

Las nuevas tecnologías son propiciadoras y gestoras de otro tipo de desplazamiento en la forma de representar.

La deformación o anamorfosis como la denomina Machado (1996) es un procedimiento observado con insistencia en expresiones audiovisuales vinculadas a las nuevas tecnologías. Pero de la misma manera que la mediatización o enmascaramiento, la anamorfosis tiene sus antecedentes en otras expresiones: las artes plásticas y la cinematografía presentan ejemplos claros de este procedimiento. Machado utiliza el término anamorfosis para designar

"todo desdoblamiento perverso del código perceptivo nacido más o menos junto con el sistema proyectivo renacentista y que constituye su negación explícita". (Machado, 1996:71)

Tyler (1973) establece una relación directa entre anamorfosis y el cine, en sus vertientes mas alejadas de las formas mas institucionalizadas de representación (que el denomina underground). Para Tyler la anamorfosis como técnica de aplicación recurre a "maneras de ver" en estrechas correspondencia con "maneras de sentir" que conforman un particular "modelo emocional" (Tyler, 1973). Y es así que al autor le es inevitable señalar un camino de esta sensibilidad puesta en juego en el cine como medio expresivo y relacionarla con otros medios de expresión más tradicionales, por ejemplo con los modelos representacionales de las artes plásticas:

"el expresionismo y el art noveau, que da la impresión de poderse curvar y moldear" (Tyler, 1973:130).

Tyler no profundiza sobre los modelos representacionales y su relación con las técnicas y herramientas de uso, a lo sumo podemos reconocer tácitamente este aspecto: el cine es el más tecnológico de los medios expresivos (hasta antes de 
los medios electrónicos y digitales) y es por esto que estas maneras de representar se vieron favorecidas. Volvamos a Machado, que sí plantea una especial preocupación por las relaciones entre modelos representacionales iconográficos y tecnologías. Machado señala:

"Se puede decir que a partir del siglo XV, el arte caminará en dos direcciones simultáneamente: en la dirección de los cánones oficiales de objetividad y coherencia y en la dirección de la deconstrucción de toda esa positividad, bajo la forma de anamorfosis... en el siglo XX, vamos a aprender a convivir simultáneamente con dos modelos iconográficos: el modelo renacentista, mantenido vivo a través de la imagen técnica y el modelo moderno del que las artes plásticas serán sus principales articuladoras “. (Machado, 1996:71).

Estos dos modelos que Machado señala coexisten para las artes en pleno siglo $\mathrm{XX}$, perpetuados según el caso por las expresiones que derivan fundamentalmente de la técnica fotográfica y de la pintura de las vanguardias, y que tienen con las nuevas tecnologías una coexistencia en los discursos audiovisuales de nuestra época. Así se puede pensar como han afectado las nuevas tecnologías las relaciones tradicionales entre la representación y el objeto representado, representación velada o producción de imagen sintética pura.

“...el videoarte será la primera forma de expresión, en el universo de las imágenes técnicas, en producir una iconografía decididamente contemporánea y en lograr una reconciliación de las imágenes técnicas con la producción estética de nuestro tiempo, (...) la imagen digital, la imagen generada o procesada en computadora, presenta una posición ambigua dentro de ese panorama. En cierto sentido, se trata de un retorno a los cánones renacentistas de coherencia y objetividad. Más que retorno, la imagen digital aparece como una verdadera hipertrofia de los postulados estéticos del siglo XV. (Machado, 1996:72)

Es interesante advertir que todo lo teorizado por Machado pone énfasis especial en lo sucedido en el terreno de lo que se ve (la imagen visual), dejando de lado, sin nombrar siquiera, si este cambio también implica o afecta la relación con lo 
que se oye, lo que se escucha, esto es la imagen sonora.

En los textos audiovisuales que estudiamos son observables procedimientos anamórficos no solo en lo visual, sino también en lo sonoro.

Revisar nuevamente algunas conceptualizaciones de la cinematografía nos permitirá aclarar algunas ideas fundamentales para nuestro posterior análisis.

\subsubsection{El modelo clásico audio-visual}

La invención del sonido en el cinematógrafo produjo un giro hacia formas de representación naturalista. En el clímax del desarrollo de la imagen visual del cine mudo, sus realizadores advirtieron de los peligros de la llegada del mundo de los ruidos, los murmullos, las voces, pero sobre todo de la palabra. De hecho, este avance técnico produce (debido a la aparatosidad del dispositivo de registro) una tendencia a los escenarios sonoramente controlados, anclados, estáticos, teatrales. Es entonces que la posibilidad de la palabra, del habla, introduce al teatro dentro de la mixtura de lenguajes tradicionales "amalgamados" por el cinematógrafo. Todo esto fue también, para el cine, la posibilidad de superar el mote de "atracción de feria" para ganarse un espacio dentro de las artes serias (Sánchez Biosca, 1996:36). Esta fue la preocupación de los maestros del mudo (el cine de la luz que no fue), había ganado la novela decimonónica, con su linealidad de relatos, con su naturalismo, con sus espacios controlados.

A partir de esto está presente para nosotros (cual ha sido y es) el modelo hegemónico en los relatos del cinematógrafo: propiciado indudablemente por sistemas culturales imperantes, poéticas triunfantes asociadas a tipos de producción y distribución, formas de ver el mundo, formas de contarlo, formas de percibirlo y hacerlo percibir.

\subsubsection{Tarkovski y Sokurov. Dos ejemplos de tratamiento anamórfico audiovisual.}


Dos filmes rusos Madre e hijo (Sokurov, 1997) y Stalker, La Zona (Tarkovski, 1989) pueden servir como ejemplo de discursos artísticos audiovisuales que escapan a la generalidad anteriormente señalada. Analicemos ambos filmes con la perspectiva de ver hasta que punto cada una de ellos delimita sistemas de representación propios que desafían los clásicos mecánico-naturalistas.

En Madre e hijo observamos un tratamiento ostensible de la imagen, mediante ópticas especiales, el mundo se nos presenta visualmente distorsionado. E paisaje, las siluetas, los rostros de la madre y el hijo, adquieren la languidez y ensoñación de la espera de lo inevitable. Más allá de toda especulación que podamos hacer sobre su uso como recurso simbólico lo cierto es que las imágenes se nos presentan desde el inicio del film hasta los créditos finales con una plasticidad pictórica que se niega como recurso narrativo codificado. Nadie dudaría que el mismo tratamiento óptico insertado en una secuencia de un film clásico nos estaría contando unívocamente un sueño o una alucinación. Sokurov no niega la alucinación o el sueño sino que los integra a la realidad de los personajes. Pero para esto el director necesita extender el recurso a la totalidad del film.

Observemos o mejor observemos y escuchemos Stalker, La Zona (Tarkovski, 1989). Concretamente la secuencia de la entrada iniciática a La Zona. Tres hombres: el científico, el escritor y el guía (el Stalker) montados en un carro transitan por las vías, los soldados, guardianes de la zona, quedaron atrás. Los tres personajes en primeros planos observan lo que nosotros no podemos (el director nos niega el contraplano: la mirada de los personajes). En la complejidad y simplicidad de un plano secuencia que pivotea en los tres personajes Tarkovski recurre en el plano sonoro a la aplicación de un recurso anamórfico aplicado al traqueteo del carromato sobre las vías, este sonido se va transformando y enrareciendo lentamente en todo el traveling hacia la zona. Los chirridos, el metal, el sonido ambiente en su totalidad adquiere el espesor de una música concreta diegetizada. El recurso se complementa con el ingreso del color con el cambio de plano (por corte) en lo que sigue al traveling y ya cuando el carromato esta detenido. 
También Tarkovski como Sokurov incorpora algo a la realidad de los personajes mediante este recurso, hasta podríamos decir que ambos directores incursionan con Tecnes y Poiesis similares.

\subsubsection{La relación referencial sonora.}

Sin embargo la relación que guarda la imagen visual anamórfica con el espectador tiene el peso de la presencia constante del objeto representado. El sonido, la mayoría de las veces, alude a un objeto (con algunas excepciones: música no diegetizada por ejemplo).

Pero: ¿Cuál es el pitido no deformado de una locomotora?, ¿Cuánto "soporta" un tratamiento deformante hasta que detectemos como espectadores el recurso? Sin embargo la más leve deformación de la silueta de una locomotora aceptablemente reconocible será advertida inmediatamente. Obviamente esta pregunta tiene respuesta en la complejidad de cada ejemplo usado para graficarlo, incluso hasta sería una tarea vana intentar construir una escala de correspondencias entre lo visual y sonoro. Lo que podemos afirmar es que el espectador está más a merced del "engaño" autoral en lo que es las imágenes sonoras. Podemos hablar de nivel de presencia, de capacidad de evocación, de representación mental.

En Hiroshima Mon Amour (Resnais, 1959) los amantes vagan por la ciudad. Sentados en un café se cuentan sus cosas. El ámbito público es reconocido como tal por el espectador. La planificación cerrada sobre primeros planos de los amantes se corresponde con la situación de intimidad: la evocación del pasado de la "niña de Nevers", la interioridad es representada estratégicamente en un progresivo asordinamiento del espacio sonoro. Por momentos los ruidos ciudadanos afloran por entre el relato oral, la máquina de música es accionada por uno de los parroquianos, esto lo vemos y lo oímos. Volver al recuerdo es sentir la textura de la voz de la mujer. El punto de vista y escucha adoptado es la del hombre que escucha a la mujer que ama (solo puede escucharla a ella)...de pronto una frase, una palabra, una acción clave nos despierta (el hombre abofetea a la mujer para "sacarla" de su recuerdo), junto con los 
personajes volvemos al bullicio del gentío y los ruidos nocturnos ciudadanos. En el gráfico 6 podemos constatar estas relaciones. La importancia, a nivel expresivo, de esta manipulación de la presencia sonora es que esta variación del umbral sonoro adquiere un carácter psicológico en correspondencia con lo que se esta narrando. La mirada de la protagonista une el pasado, la evocación de una experiencia traumática, con el presente. Recurso ya conocido para nosotros, el flash back tan solo necesita de esa cesura que da la mirada. Pero lo que si es novedoso es ese tratamiento, esa anamorfosis de la imagen sonora, deformación que tan solo es y se concretiza en ese asordinamiento del mundo de los sonidos que para nosotros se corresponde con la adopción de un punto de escucha que coincide con la mujer que recuerda. 

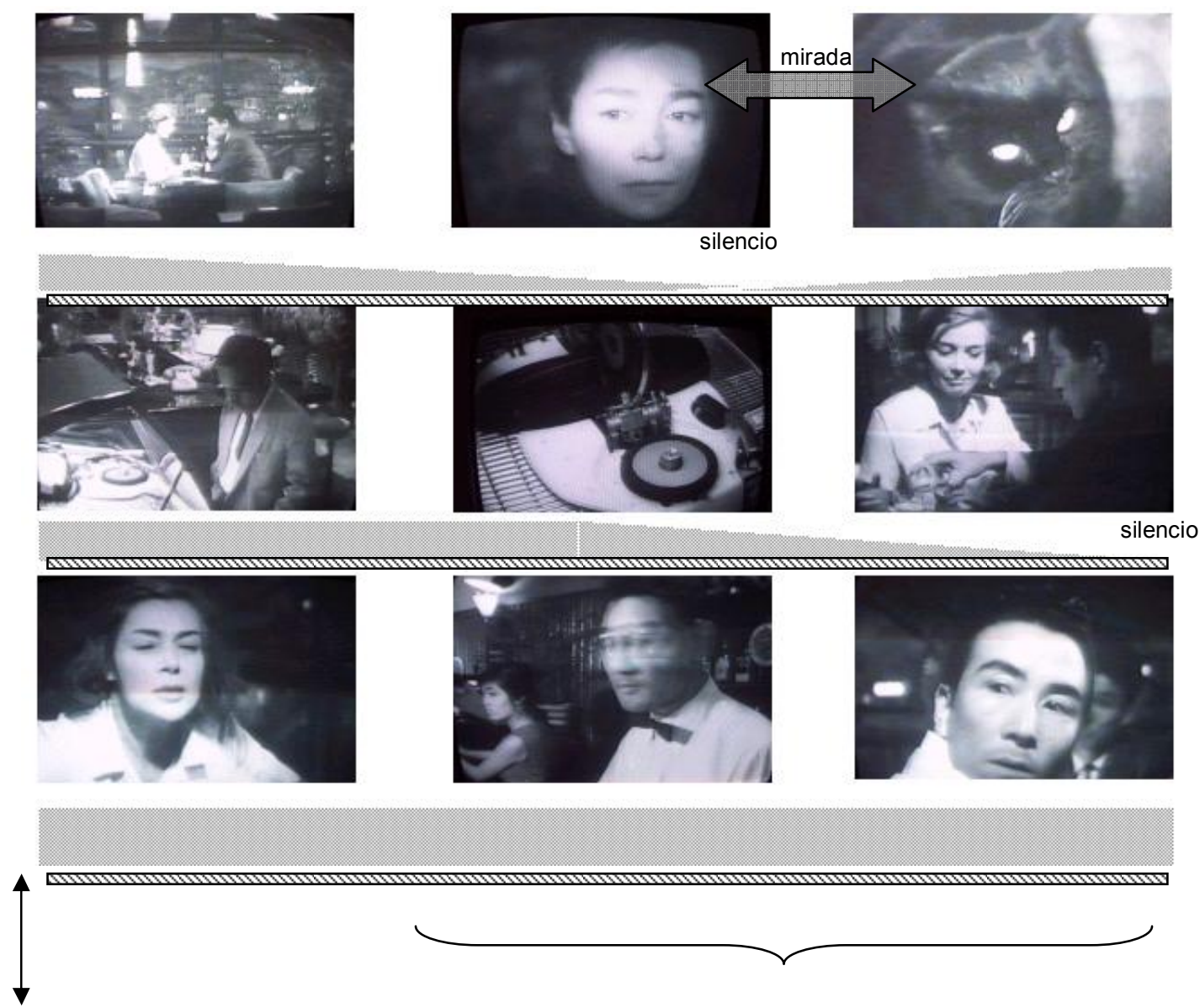

Desde el silencio ambiente corte a los ruidos ciudadanos sobre el

Planos de corta duración, se acelera el montaje visual en correspondencia con la entrada de los cambio de plano y bofetada ruidos de la ciudad

Voz de los personajes

Ruido ambiente 
"Deformar lo que vemos" implica necesariamente la presencia de un objeto visible habitualmente reconocible como tal y en su deformación.

"Deformar lo que oímos" implica necesariamente la presencia del sonido, no siempre identificable con la fuente sonora, no siempre identificable sus parámetros normales. El sonido goza de mayor grado de libertad en relación al referente.

Veamos, que nos será útil para profundizar en el tema, la clasificación que Chion hace de lo que él denomina escenario audiovisual (gráfico 7) (Chion, 1993:80).

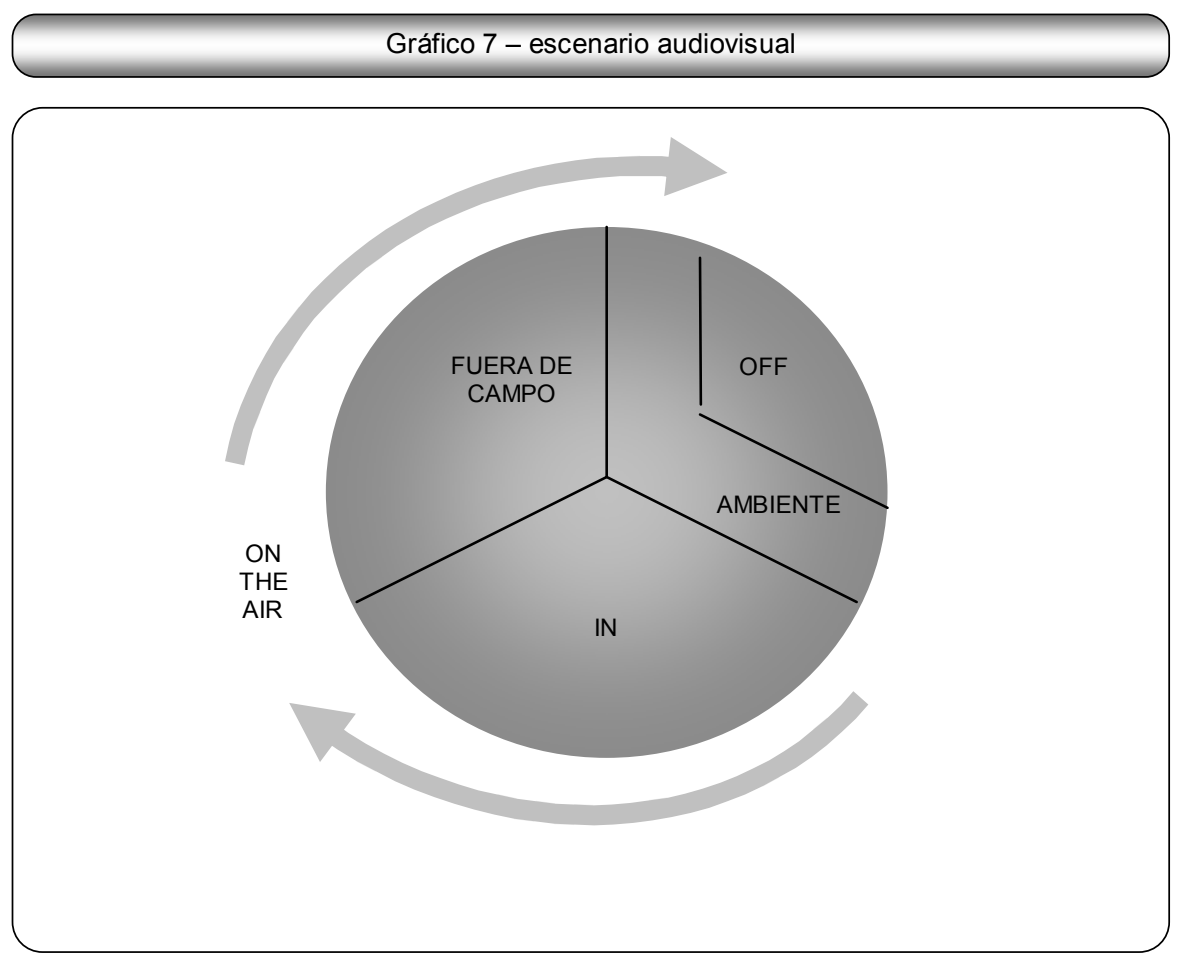

La característica de la imagen sonora determina la inexistencia de un marco (presente y fundamental para la imagen visual). Esta falta de continente del 
sonido define la tendencia del mismo a buscar su lugar en el marco o fuera de él. Esta característica es lo que plantea la anterior clasificación que define a los sonidos de un film según y en relación con lo que sucede con la imagen visual y el marco que la contiene o no. Existiendo entonces sonidos que tiene su fuente visualizada, y sonidos acusmáticos (que se oyen sin ver la causa del sonido, su fuente, su causa).

De esto se deduce el mayor grado de libertad señalado, un sonido puede tener una fuente en campo o fuera de él, un sonido puede no tener una fuente identificable. A lo que podemos agregar cierto margen de variabilidad sobre la normal.

Es importante para nosotros tener presente todos estos aspectos desarrollados hasta aquí. Los textos audiovisuales que serán observados según nuestro modelo lector-escritor son imágenes visuales en articulación con imágenes sonoras.

Según lo expresado, en las posibilidades de romper con el vínculo referencial se involucran ambos tipos de imágenes. Tanto imágenes visuales como imágenes sonoras pueden ser manipuladas (mediante filtros de software en la posproducción por ejemplo) que la apartan de la fidelidad para con su objeto originario.

Una imagen visual puede ser estirada, aplastada, retorcida. Un sonido puede reverberar, una imagen visual también. El término anamorfosis puede y debe ser extendido y aplicado en el parámetro temporal.

Estos desplazamientos en las formas clásicas de representar son fenómenos claramente propiciados por la existencia de las nuevas tecnologías en la producción de textos audiovisuales.

\subsection{Lo serial como esencial}

\subsubsection{La posproducción}


Uno de los procesos de la fase productiva audiovisual más profundamente afectados ha sido el llamado proceso de posproducción. El acto mismo de armar, de editar, de montar cada uno de los trozos de espacio-tiempo que son cada uno de los planos ha tenido modificaciones profundas en lo que es las herramientas tecnológicas de uso en la misma etapa productiva. $Y$ como es esperable la modificación de las herramientas es razón de cambios del producto audiovisual. A fines del planteo de nuestro marco teórico es entonces de fundamental importancia poder revisar puntualmente algunos conceptos referidos a esta fase productiva audiovisual diferenciada. Tradicionalmente, y con cierta rigurosidad que proviene más de posiciones artesano-profesionales, se ha distinguido la palabra montaje (para cuando dicho proceso se realiza en material fílmico cinematográfico) de la palabra edición (que designa el mismo proceso pero para material videográfico).

Lo cierto es que con una mirada que enfoque el tema desde el ámbito de la escritura este proceso sería equiparable (articular planos entre sí, articular secuencias entre sí, tanto visuales como sonoras), solo se distinguiría en cada caso la plataforma tecnológica: soporte del material, tecnología para realizar el proceso, etc.

Pero sucede y esto es lo que nos interesa aquí, que estas diferencias en las tecnologías inducen esquemas mentales, propician distintos tipos de inferencias, relaciones que obviamente se traducen en mayor o en menor medida en el producto audiovisual final.

La denominación sistema lineal de postproducción define a la operación resumiendo perfectamente el carácter secuencial unidireccional en el trabajo de montaje. Sin embargo, la denominación no-lineal no hace referencia a importantes características que le son propias, como son la serialidad, las posibilidades combinatorias y permutativas inclusive las formas de romper la linealidad a nivel estructural en el desarrollo de una trama o red. 
Revisar algunas características de las series numéricas nos puede servir para el caso: una serie se formula a partir de un factor numérico constante y un factor variante dependiente de un contador.

Según la tendencia o no a un valor se las denomina series de convergencia o de divergencia. Los conceptos binarios convergente - divergente, cerrado abierto, pueden ser planteados para la resolución a nivel estructural de lo serial.

En una estructura audiovisual que usa de lo serial como un recurso tecno expresivo el factor constante es el elemento base (visual o sonoro), el factor variante es la aplicación diferencial (modulación, ajuste, efectización de alguno de sus parámetros constitutivos, visuales y/o sonoros) generalmente producido mediante una herramienta del propio software.

Las formas de posproducción digital-nolineal ofrecen desde su plataforma tecnológica la producción de series: un sonido ruido base repetido con diferentes tratamientos y ecualizaciones no es una solución privativa del sistema no lineal, pero la clonación (copy-paste) y la variación (diferenciación) mediante por ejemplo la aplicación de una función variativa a cada clon son elementos existentes, especificados, denominados herramientas en el software de aplicación, mientras que en un sistema lineal el procedimiento sería llevado a cabo mediante maniobras externas a la plataforma tecnológica. 


\subsubsection{Las herramientas en la posproducción}

“...todos esos efectos que puedes extraer de la repetición de una imagen o un sonido..." (Bresson, R., 1997:48)

Como decíamos uno de las instancias realizativas, parte del proceso de producción de un texto audiovisual, que ha sido profundamente afectado es el de la posproducción.

Detectamos un reemplazo técnico radical en esta fase productiva. Según lo que venimos sosteniendo estos cambios en las herramientas tendrían su repercusión en las formas audiovisuales. Independientemente de las intenciones puestas en el guión, como pre-visión de texto audiovisual a realizar, el momento de la edición, del montaje, no es un momento rígido en el sentido de que no permite cambios sobre el guión. No obstante, entre los alumnos, es bastante generalizada la idea de que el montaje (la posproducción) no es precisamente un momento creativo sino la posibilidad de resolver las dificultades del rodaje (la grabación) plasmadas en el material que debemos montar.

Más allá de estas concepciones estético productivas de los alumnos, sabemos que en el momento mismo del armado de los textos audiovisuales la tecnología del ordenador ha sido factor central, que ha modificado el método de armado, que ha inducido nuevas formas de relacionarse con el material y que esto necesariamente influyó sobre el producto final.

Como punto de partida para diferenciar las condiciones de posproducción lineal y no lineal, podemos intentar hacer un análisis a la luz de dos esquemas base que consideran las condiciones de flujo o movimiento de la información. Mientras en un sistema lineal el flujo está dado segmento a segmento (gráfico 8), controlado por una llave que permite el paso de cada unidad previamente ubicada en puerta, en un sistema no lineal la información es contenida, retenida en un reservorio para su ordenamiento y procesamiento. 


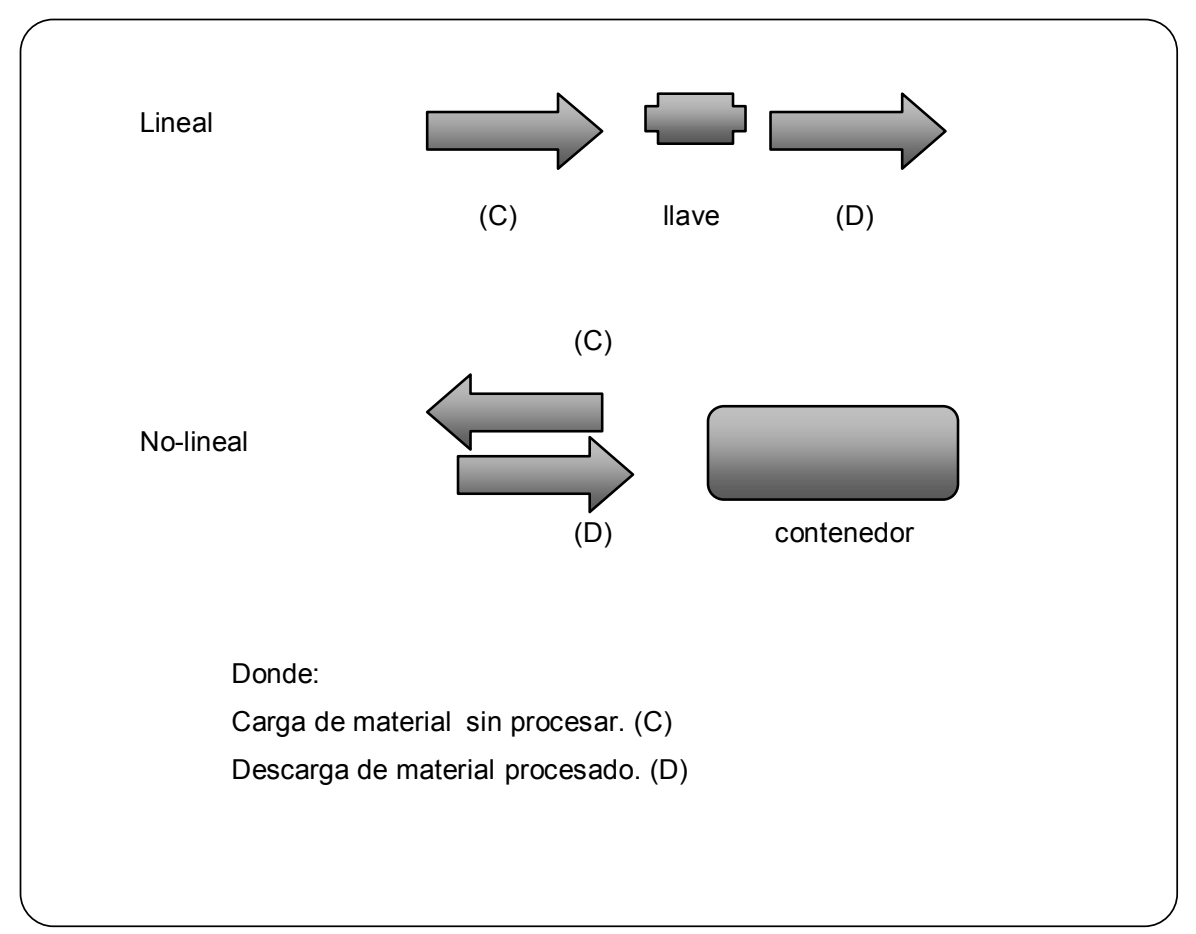

Designamos montaje al proceso por el cual se ordena y determina la duración de planos (fragmentos o segmentos de imágenes visuales y sonoras para una definición más amplia). Entendiendo que el ordenamiento es tanto a nivel unidireccional en el eje temporal, como espacial (en el sentido de la construcción de un collage de recortes, sobreimpresiones, capas, etc.)

En uno y otro sistema observamos las siguientes diferencias:

- En el sistema lineal las determinaciones de orden vienen dadas en la flecha de entrada y las duraciones por el accionar de la llave.

- En el no lineal las definiciones de orden y duración se realizan en el contenedor.

- En un sistema analógico (lineal) el material sufre en el copiado una degradación permanente. 
- Las posibilidades de clonación del material, tanto visual como sonoro, tiene en el sistema digital (no lineal) la característica de esencial constitutivo.

- En el sistema lineal las herramientas se diferencian, manteniendo la distancia y diferenciación entre las señales. Se dispone de una consola para el sonido (ecualizador, control de volúmenes, efectos) (gráfico 9) de funcionamiento analógico y/o digital. La señal de vídeo es tratada mediante una consola de aplicación de funciones digitales predeterminadas y acotadas con entrada y salida analógica. Las herramientas son bien diferentes, de aplicación y uso diferenciado. La visualización y escucha para el operador no tienen otro lugar de relación que no sea la de la reproducción del material procesado. 


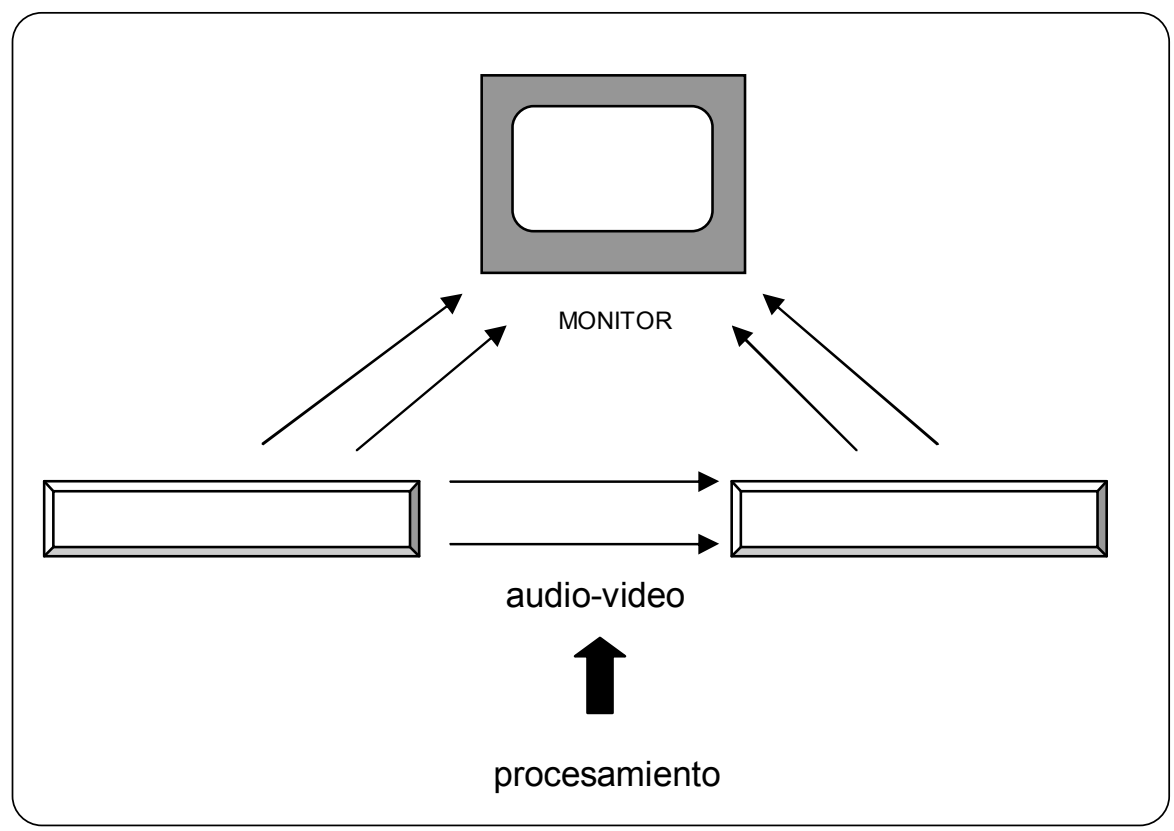

- En un sistema no lineal se ve la banda de sonido del mismo modo que la banda imagen. Se equipara la forma de ver y procesar la señal visual y la de audio. La tendencia de normatización de los distintos software iguala las herramientas, tanto en procedimientos, como en presentación, nomenclaturas y uso.

El sonido se puede "ver" en la mesa de armado del proyecto.

La imagen se esquematiza en la presentación segmentada por frames, es una tira con un rótulo gráfico que informa sobre la imagen que contiene. La visualización de ambas señales en la operatoria se modifica profundamente.

La visión gráfica del proyecto (frame a frame si se quiere) presentado sobre una mesa de armado puede ser vista como una emulación del trabajo manual en una moviola (gráfico 10). Sin embargo el montaje de celuloide no abandona un esquema lineal secuencial del armado, tengo todo el material, pero enrollado en las bobinas, solo puedo ver en el visor de la moviola un instante, el seleccionado: "estoy parado aquí, y recuerdo lo que hay por delante y lo que hay por detrás". En una edición lineal diría: "estoy parado aquí, recuerdo lo que hay detrás e imagino lo que vendrá. “ En un armado 
no lineal tengo una visión de la totalidad, puedo visualizar un mapa estructural.

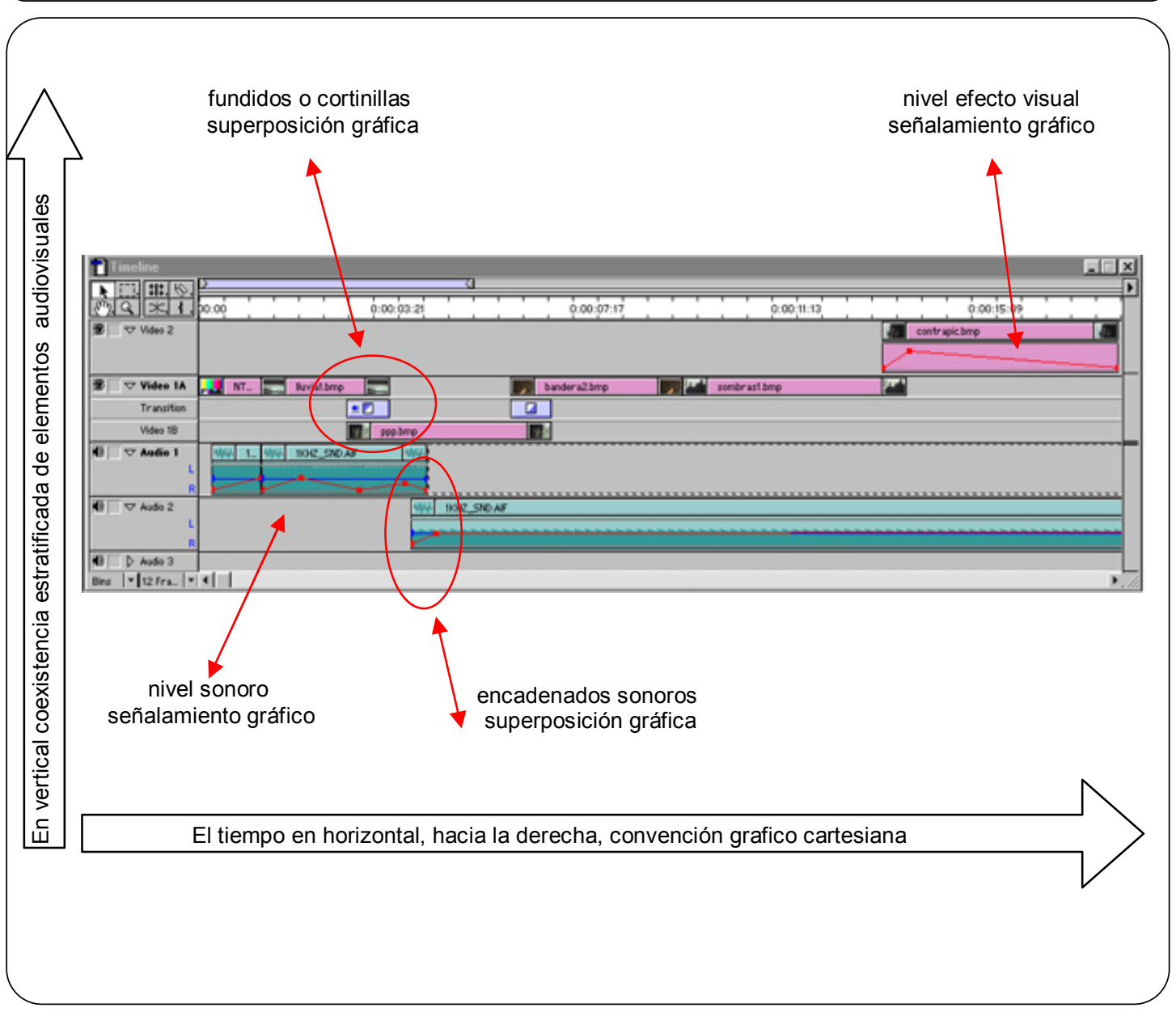

Todas estas diferencias que se presentan con el uso de uno u otro dispositivo afectan (a veces profundamente) las soluciones en las construcciones de sentido del producto audiovisual.

\subsection{Un nuevo montaje. Interactividad y lectura aleatoria}

\subsubsection{Algunas premisas}


Decíamos que las consignas pedagógicas para la producción de los textos audiovisuales objeto de nuestro estudio, permitían la factura de ficciones audiovisuales en cualquier soporte. Es así que lo fílmico, y lo videográfico se veía ampliado potencialmente por los nuevos soportes (asociados necesariamente a las nuevas tecnologías). Existía entonces la posibilidad de que los alumnos realizaran una producción ficcional con elementos interactivos. Una ficción en cd-rom, una ficción publicada en Internet eran posibles textos audiovisuales ficcionales a producir por los alumnos.

La interactividad implica necesariamente un reposicionamiento del espectador, del lector del texto audiovisual. El acceso aleatorio facilita la posibilidad de realizar, de plasmar en una estructura narrativa concreta ese jardín de los senderos que se bifurcan (Borges, 1980). A nivel relato estas nuevas formas permitirían acceder a distintos rizomas, plantear distintos finales, ramificar en divergencias y/o convergencias, etc.

También es cierto, que más allá de los soportes, los relatos de ficción tradicionales se han visto afectados formalmente. Un ejemplo claro de esto lo podemos observar en el film Corre Lola, Corre (Tykwer, 1998) que ha pesar de ser un film de largometraje en $35 \mathrm{~mm}$ en donde su lectura esta claramente definida como lineal unidireccional se hace uso en su estructura y articulación de formas que emulan procesos de elecciones múltiples, retrocesos y cambio de finales. Esta emulación de formas interactivas también nos interesa. A fines de la observación y análisis de nuestro objeto de estudio debemos entonces diferenciar entre textos ficcionales audiovisuales interactivos y textos audiovisuales ficcionales que incorporan en emulación elementos de interactividad. Lo anterior se puede resumir según los esquemas del gráfico 11. 

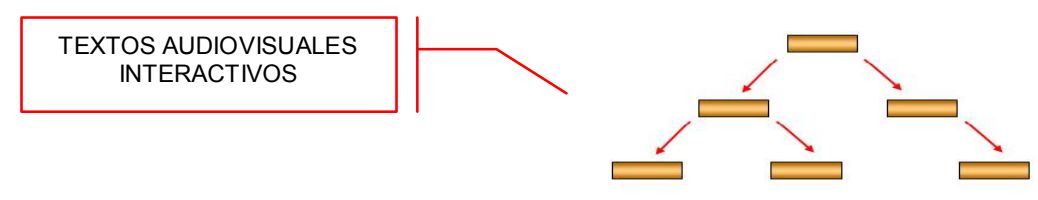

TEXTOS AUDIOVISUALES

LINEALES CON EMULACIÓN INTERACTIVA

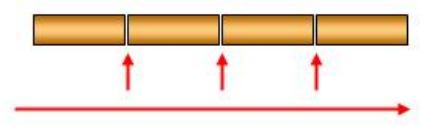

Para ambos casos se observa la existencia de nuevos recursos formales que afectan un texto audiovisual. En el segundo caso podemos hablar de permeabilidad en los recursos.

Esta permeabilidad obviamente depende de actitudes o búsquedas expresivas individuales. Podemos reseñar como antecedente las incursiones de los artistas plásticos con las nuevas tecnologías planteando puntos de convergencia con la imagen videográfica, emulando por ejemplo la textura de un píxel electrónico o el grafismo videográfico.

Todo lo dicho hasta ahora parte de la premisa de cierta delimitación en las disciplinas, pero esto también puede ser puesto en duda, es posible pensar que las nuevas tecnologías vienen generando cierta convergencia (no solo en los medios expresivos), que han progresivamente borrado las antes claras fronteras entre la pintura y el cine, entre la TV y el vídeo, entre el ordenador y los demás medios tradicionales. Como nos señala Murray: 
"El ordenador es (...) un medio de representación, una forma de modelar el mundo que añade sus propias y poderosas propiedades a los medios tradicionales que tan rápidamente ha asimilado." (Murray, 1999:291).

El ordenador añade propiedades a los medios tradicionales, es así que nuestros textos audiovisuales observados además de presentar los conocidos y tradicionales recursos de montaje como son: mirada de los personajes, y todo tipo de articulación del espacio y del tiempo según formas clásicas; presentan además elementos de enlaces (links) reales articulando la ficción (en el caso en que el soporte lo permita) o enlaces simulados en lo formal (en el caso de soportes lineales).

Este apartado de análisis se propone revisar algunas ficciones en Internet con la perspectiva de llegar a algunas conclusiones con respecto al uso de técnicas de montaje en Internet (propias y-o heredadas de los otros medios expresivos en general y de los medios audiovisuales en particular). 


\subsubsection{El montaje en Internet}

El montaje no es privativo de ninguna disciplina artística-expresivacomunicativa, sin embargo podemos afirmar que el montaje cinematográfico y la reflexión teórica sobre el mismo se han establecido como un terreno de integración de lo conocido hasta el momento. El factor temporal, a través de la secuencialidad, ha permitido extender lo que habían sido conceptos puramente espaciales desarrollados por la pintura, la escultura, la arquitectura. La duración, concepto aplicable a la expresión musical, con el cine encontró desarrollo en las imágenes no solo sonoras sino también visuales. Revisemos ahora algunos de los cambios experimentados por el montaje, en particular la ruptura del tratamiento lineal secuencial que es la principal característica derivada del advenimiento de las nuevas tecnologías en su aplicación a Internet.

Una primera mirada sobre el montaje en Internet nos permitiría distinguir distintas relaciones y condiciones que afectan a la pantalla en particular. El ordenamiento espacial del texto escrito y las imágenes, es una operación de montaje. El diseño gráfico como disciplina se ocuparía de la tarea de delimitar la partición de la pantalla, haciendo uso del movimiento (en iconos, en frases), los fondos (sus colores), como una forma de hacer resaltar o señalar ciertos sectores.

También existiría un montaje entre pantallas. Los recursos puestos en juego en este caso son aquellos que surgen de la condición de una "pantalla táctil" que permite presentar para ser tocados los denominados anclajes, íconos, palabras o frases señaladas, imágenes (estáticos, o dinámicos) que generan asociaciones (links) con otra pantalla.

La estructuración bajo un esquema de asociaciones posibles entre pantallas deja la posibilidad de dar más o menos libertad al lector en la elección de uno u otro camino. Es así que las libertades de un hipertexto es potencial significante. 
Un hipertexto puede presentarse en forma de estructura axial o en red (Landow, 1997:110). Los esquemas básicos a lo que responderían estas configuraciones podrían esquematizarse según el gráfico 12.




Ambos modelos presentan casos extremos. La estructura en red no permitiría, a priori, una organización y vinculación escalonada con señalamientos jerárquicos.

La secuencialización de contenidos a la que el lector del hipertexto no puede escapar en la estructura axial, responde a una vinculación más ortodoxa (ya existente en textos lineales).

En este sentido la claridad expositiva de los contenidos está garantizada, el lector ortodoxo es aquel proveniente del libro, la lógica axial permite organizar señalando prioridades, impide procesos más participativos por parte del lector.

Es así que aquello que señalamos como potencialidad significante disponible para ser experimentada por el lector en su navegación está particularmente garantizada en una estructura que se organiza en red. En este caso el lector no solo interpreta más o menos libremente, sino que también organiza y estructura, incluso al nivel mismo de la producción.

Observando los enlaces podemos evaluar el grado de interactividad en la determinación de las siguientes variables:

$\checkmark$ Frecuencia (de interacción)

$\checkmark$ Extensión (cuantas posibilidades de elección son presentadas)

$\checkmark$ Significancia (grado de distinción entre las distintas posibilidades de diferenciación de caminos) 
Dependiendo de los valores que tomen estas variables el grado de interactividad será modulado para lo que se considera un texto interactivo. La posibilidad de una estructura abierta (al lector) se encuentra con el límite de generar un texto caótico.

Este límite (en el cual se transforma en un texto caótico) dependerá obviamente del tipo de texto que se pretende. Por ejemplo podemos imaginar que un hipertexto poético-artístico sacará partido de ciertas indeterminaciones o libertades contrariamente a lo que sucedería con un hipertexto pedagógico o de promoción institucional.

Existen también clasificaciones que aluden a las características arquitectónicas del hardware, desestimando o relacionando el proceso comunicativo interactivo a la existencia y posibilidad tecnológica de un dialogo máquina usuario.

A modo de ejemplo:

Nivel 0. Programas lineales. Subsumisión total del receptor a las coordenadas espacio temporales. Sala cinematográfica tradicional.

0 Nivel 1. Conectar, desconectar, retroceder, etc. Reproductor de vídeo. Mando a distancia.

Nivel 2. Acceso aleatorio con ramificaciones simples. Teletexto.

Nivel 3. Acceso aleatorio e interactivo a los contenidos. Ramificación y estructuración ilimitada.

a Nivel 4. Se agrega una potente bidireccionalidad con periféricos o subsistemas en red. Por ejemplo TV digital. 
Lo cierto es que la existencia de una arquitectura de hardware acorde no garantiza necesariamente interactividad, son los contenidos y su estructura lo que define básicamente los distintos niveles de participación.

a Participación selectiva. Elegir solo entre lo ofrecido.

0. Participación transformativa. Transformación de la estructura y contenidos por el receptor (según previsión del autor: la simplicidad de la estructura o la pobre oferta de enlaces delimita las posibilidades del lector para participar constructivamente en el texto).

0 Participación constructiva. El receptor construye junto con el autor, es autor también en la medida en que no es guiado por quien se presenta como autor del texto. (Moreno, 1998:143) 


\subsubsection{Los textos audiovisuales en Internet. Aproximaciones.}

La función referencial del lenguaje es un aspecto que se pone de manifiesto con particular intensidad en el momento de estudiar los nuevos modos expresivos, ya hemos abordado el tema en el recorte de la relación imagen visual- imagen sonora.

La relación con el referente en lo audiovisual puede adoptar la técnica de reproducción fiel, de mímesis, pero de todos modos esto no anula la posibilidad de una funcionalidad poética que se evidencia a partir de un trabajo de construcción semiótica.

Es así que las problemáticas de cómo representar y cómo construir se hallan profundamente implicadas y entrelazadas en el mismo proceso de reproducir expresivamente.

Sabemos que las nuevas tecnologías nos han puesto frente a imágenes de síntesis en donde lo espacial, lo temporal, y el punto de vista (ubicuidad perceptual) es radicalmente reformulado. Lo representado es mudable, las coordenadas habituales son relativizadas, reformuladas y refutadas en la experimentación del espectador-lector.

Estos aspectos (de ubicuidad perceptual, de punto de vista, de lectura) no solo responden al problema de la referencialidad puesta en juego sino también a la reformulación de aspectos que más tienen que ver con estructuras y sintaxis del propio lenguaje audiovisual.

Aristóteles define categóricamente la estructura formal tradicional según principio, medio y fin.

"Un principio es aquello que en sí no es necesariamente precedido por otra cosa y que naturalmente tiene algo después. Un fin es aquello que naturalmente viene a continuación de otra cosa, como su consecuencia necesaria o 
habitualmente; un medio es aquello que por naturaleza esta después de algo y que tiene algo después." (Landow, 1997:101).

La idea de linealidad, de secuencialidad es la que está presente en esta definición, no importa tanto el núcleo, el interior, el contenido de cada parte como el inexorable encadenamiento: de algo se viene, hacia algo se va y esto no es mutable, está cristalizado en la obra.

El hipertexto como escritura se ha planteado y reformulado estos esquemas, estructurándose a través de nexos que posibilitan trayectorias diferenciadas para el lector. La línea, dirección única, sentido único, es entonces reemplazada con diseños que siguen apelando a la geometría euclidiana en su explicación:

"El poema puede diseñarse como un motivo de cuadros anidados, un grupo de círculos encadenados, una trenza de distintos temas visuales y gráficos, una doble hélice..." (Landow, 1997:103).

Ya hemos señalado el recorte que nos permitimos realizar en este estudio: nos interesa específicamente lo que sucede en los relatos audiovisuales de ficción. La ficción hipertextual tiene sus primeros abordajes y experiencias realizativas, como es esperable, en forma escrita, experimentos literarios (narrativos y poéticos). El avance tecnológico posterior permitió incorporar imágenes, e imágenes en movimiento.

La mejora de las posibilidades de accesibilidad ha hecho que el panorama actual sea bastante vasto y variado. Hay en la red desarrollos importantes de ficciones audiovisuales hipertextuales en formatos del tipo televisivo serial, también de técnicas de animación, muchas asociadas a algún proyecto empresarial aunque también es importante la existencia de audiovisuales hipertextuales de tipo expresivo".

La interactividad es el aspecto clave que se ha abordado en el análisis de las ficciones del anexo de Ficciones Audiovisuales Interactivas. Se observa que lo lúdico surge en general como estrategia para garantizar y darle sentido a esta 
interactividad. La industria del videojuego como un hollywood de las nuevas expresiones (asociadas a las nuevas tecnologías) constituye una fuente de retóricas visuales, discursos, morfologías etc.

Una visión simplista nos llevaría a desestimar los aportes de esta industria cultural. Por ejemplo una mirada sobre la situación actual nos podría tentar a pensar que el único camino transitado por los videojuegos ha sido el de generar infografías que reproduzcan espacios de perspectivas renacentistas tradicionales (simuladores de vuelo, coches, escenarios de combate, campos de fútbol, etc.), sin embargo no es más que un estado de situación, para comprobarlo bastaría con apuntar los aportes en planteos más conceptuales que no solo son historia del género (Tetris, Puzzles en general) y que han tenido últimamente una revisión y reinserción, a veces en mixtura con juegos de destreza, de lucha, de combate. Complementando de esta manera el vertiginoso desarrollo de la hiperrealidad mimética con la revalorización no solo el concepto, sino también de otro tipo de infografía y representación.

1- Ver anexo Análisis de Ficciones Audiovisuales Interactivas. Para fundamentar algunos conceptos de nuestro marco teórico se realizó el análisis de tres ficciones audiovisuales de existencia en la red. Las narraciones, elegidas por su pertenencia genérica, permiten obtener algunas conclusiones esquemáticas. La interactividad se tipificó en su grado de interacción y forma en que esta se articula. Esto dio parámetros fundamentales para valorar el sistema de navegación en lo que a su efectividad se refiere. 
Sin embargo en los ejemplos analizados se pone de manifiesto un aspecto importante: que la industria del entretenimiento considera al mundo de los bits como tan solo un nuevo canal de distribución, un simple cable para llevar sus vastas reservas de contenido hacia otros mercados.

“...parece que seguirán siendo conservadores a la hora de crear productos digitales y se concentrarán simplemente en sus intentos de modificar el formato familiar del cine y la televisión para convertirlos en algo interactivo..." (Murray, 1999:262)

Los ejemplos elegidos son más que paradigmáticos. El culebrón, la publicidad y el cine-terror son espacios discursivos bien codificados. Tanto en su distribución vía televisiva (culebrón y publicidad) como cinematográfica-televisiva (género terror) apelan a recursos de lenguaje audiovisual reconocibles, cristalizados.

La forma de planificar (puesta de planos), el tratamiento con los actores, las retóricas visuales, el uso de la música, son algunos de los aspectos que sabemos son determinantes en lo formal para definir la pertenencia a algunos de los géneros en particular.

Los ejemplos analizados, como ya se señaló, cumplen estas reglas de género. Cabría preguntarnos ¿qué novedad hay (privativo del nuevo medio de distribución) en los ejemplos analizados?

La única ficción que incursiona en nuevos recursos es Los Profesionales, haciendo uso, como ya se ha explicado, de ramificaciones de guión y puntos pausa-interactiva. Estos recursos actúan a dos niveles, a saber:

- Interactividad como posibilidad de elección en un "menú narrativo"

- Interactividad con cierta asignación primaria de mirada-personaje, observador que interviene etc. pero sin consecuencias en la secuencialización de la historia. 
Hablar de videojuegos, el más desarrollado espacio de ficción interactiva, es hablar de operar fundamentalmente a nivel mirada del espectador, así sea mediante la construcción de una subjetiva que llegando al extremo de hacerlo en una envolvente sensorial, construye una virtualidad, una realidad virtual.

Reformulemos la pregunta entonces (mejor para nuestra exposición) ¿qué no hay, pero podría haber en función de las potencialidades del medio? Murray (1999) nos propone una interesante ampliación del escenario:

"Igual que la cámara de cine hizo que el escenario del teatro pareciera de pronto demasiado limitado, el ratón del ordenador acabará haciendo que la cámara del director nos parezca limitada. Los espectadores interactores querrán seguir a los actores fuera del encuadre y ver las cosas desde puntos de vistas diferentes". (Murray, 1999:268).

Este comentario permite introducirnos en la idea de construir nuevos puntos de vista para el espectador. Una mirada ampliada panóptica (seguir a los actores fuera del encuadre) es una posibilidad. También lo sería la posibilidad de elegir montajes alternativos, que involucrarían el posicionamiento diferenciado del espectador frente a la misma historia. Podemos imaginar en la "ficción-web" Aulas de sangre a un lector que puede ser detective de la historia de crímenes mediante el acceso a pruebas, a indicios en la escena del crimen, etc.

Recursos como los puntualizados introducirían elementos para la participación del espectador-lector permitiéndole cambiar actividades secuenciales (ver, luego interactuar: premisa a la que no llega el caso de El pianista relamido) a actividades simultaneas pero separadas (interactuar al tiempo que se ve: sería el caso de Los profesionales en sus pausas interactivas), y en camino hacia una experiencia común (ver e interactuar en el mismo entorno: premisa que no cumple ninguno de los ejemplos analizados).

Murray, en superación del encuadre cinematográfico propone, "puntos de vistas a la carta" (a elección del espectador). ¿Qué modifica en un texto audiovisual ficcional una multiplicidad de puntos de vista? Mejor dicho: Murray nos habla 
desde las aparentes falencias y necesidades superadas: el escenario teatral es ampliado por la cámara cinematográfica (de ojo fijo a ojo móvil). La cámara (único ojo, el definido por el director-realizador) será reemplazado por el ojo múltiple de la ficción interactiva.

Según esta lógica el camino es el que se rehace en la superación de supuestas limitaciones de movilidad y multiplicidad de puntos de vista. Pero permitámonos poner en crisis esta visión positiva. Para esto problematizemos nuestro objeto de estudio desde su multiplicidad de objeto comunicacional y expresivo.

Concretamente formulemos la siguiente pregunta ¿Qué es lo que varia en la ficción audiovisual a nivel expresivo por la incorporación de un "ojo múltiple a la carta"? 


\subsubsection{La mirada en crisis}

"Sueño con un nuevo mundo magnífico y deslumbrante que se derrumba en cuanto se encienden las luces. Un mundo que se desvanece pero no muere, porque basta con que me quede inmóvil otra vez y que mire fijamente y con los ojos bien abiertos a la oscuridad para que reaparezca...no creo que sea propiedad mía exclusiva: lo único que es exclusivo es mi ángulo de visión" (Miller, 2002:17).

El concepto de mirada es por demás clave en el análisis de la estructuración de un texto audiovisual. Según Bresson el cinematógrafo es "unir, relacionar a los personajes entre sí y con las cosas a través de la mirada" (Bresson, 1997:22). Esta premisa nos permite repensar con un criterio más general concepciones enfrentadas por diferentes formas de entender el cine. En el cine siempre lo representado en la pantalla está siendo mirado, no solo visto, que implica más el acto sensorial fisiológico, sino mirado, recortado del resto del mundo, de una totalidad que sigue existiendo en la ausencia. "El quadro, el marco es lo que hace que la imagen no sea ni infinita, ni indefinida; lo que termina, lo que detiene la imagen." (Aumont, 1997:81). Este terminar o detener la imagen, adueñarse de una porción del mundo, es propiciar la mirada. Esta mirada es del espectador pero también de los personajes representados en la pantalla. Podemos avanzar aún más si afirmamos que esta mirada del espectador existe gracias y a través de una red espacio-temporal y que esta red, esta estructura, se arma gracias a la mirada relacionante de los personajes y las cosas representadas.

Según esta premisa se puede pensar la estructuración de un espacio y tiempo no solo a través del corte, del pegado plano a plano, sino también al interior de cada plano. Bresson (1997) nos habla de imágenes conductoras de la mirada. Pensado en sistemas de representación audiovisual tradicionales, la incorporación del espectador es "atrapamiento de su mirada" (Sangro Colón, 2000:296). 
Es así que la puesta a punto de elementos que construyan una mirada para el espectador-lector serán aquellas que permitan ir planteando un espacio y tiempo para ser habitado por el mismo, habitabilidad que en la cinematografía ha sido resuelta en la transparencia.

El término ciberdrama sirve solamente para situarnos de cara a lo que nos espera... la necesidad humana de representación, de contar historias y utilizar la imaginación de una forma creativa es parte de nuestro ser, y el potencial narrativo del medio digital es impresionante. El mundo virtual irá aumentando su expresividad, y nosotros nos iremos...en algún momento dejaremos de mirar el medio para mirar a través de él...cuando hayamos llegado a este punto, cuando el propio medio se convierta en transparente estaremos perdidos en la representación y nos preocuparemos solo por la historia. (Murray, 1999:280)

Existe una dialéctica compleja entre la búsqueda de una escritura transparente, proceso indispensable a todo medio que busca cristalizar su retórica, convencionalizarla, como lo han hecho la imprenta, el cine, la tv, etc., y aquello que es esencial a todo texto audiovisual hipermedia, esto es su potencialidad en la no linealidad. El relato lineal ha sido un estabilizador para cada nuevo soporte expresivo. $\mathrm{Y}$ es así que gran parte de la transparencia cinematográfica está apoyada en este esquema o estructura retórica. Sin embargo los discursos articulados en las nuevas tecnologías parecen seguir un camino asociativo similar al funcionamiento de la memoria humana. (Bush, 1945) 


\subsubsection{Entre la información y la transformación.}

Sabemos que la idea de límite, de discretización, de recorte es lo que posibilita la existencia de todo lenguaje. Sabemos también que, a veces, superando un concepto puramente informacional, un juego de ocultamientos, de luces y sombras, puede proponer un espacio expresivo más habitable para el espectador/público.

Parece clave la idea de que todo discurso expresivo debe plantearse el completamiento en el lector Comolli deja entrever en sus escritos un claro posicionamiento en relación al fenómeno cinematográfico: la pantalla muestra pero oculta: "Doble sentido de la palabra pantalla lo que se ve y lo que se esconde." (Comolli, 2002:66). El cuadro es siempre un recorte de la totalidad, escritura del campo, y fuera de campo. El cinematógrafo como medio expresivo ha sido consciente en el uso de la "escritura de la ausencia y la presión de la invisible" en un juego a las escondidas con el "deseo de saber y de ver del espectador".

Pero la historia de la escritura con imágenes no solo ha recorrido este camino. Al concepto de arte cinematográfico lo acompaña el de industria y espectáculo. Y es así que, como empresa del espectáculo, el cine ha sido también ventana para el deseo de ver y consumir efectos. Con estos conceptos la escritura con imágenes ha implantado un espectador inmóvil. El uso del término inmovilidad intenta graficar el concepto de un espacio (cinematográfico) que no se habita, que no es recorrido por el espectador que (metafóricamente hablando) se encuentra quieto, solo esperando se le den más imágenes que consumir.

A este espectador se opone según Comolli un espectador móvil, con relaciones complejas y emociones contradictorias, público de la cinematografía heredera del encuadre, la línea y el color de la pintura, continuadora de las ansias referenciales de la fotografía y de las proporciones del ritmo y la duración de la música. Este espectador es móvil pues puede ocupar, permutar su lugar en el film. 
Filmar es "materializar el cuerpo y simbolizar la mirada" (Comolli, 2002:81), los cuerpos, los objetos, el mundo, son representados, la mirada es ante todo la estrategia de la conversación a nivel textual, es lo que básicamente construye esta movilidad del espectador-lector.

Pero ¿De que manera todo esto funciona en el hipertexto? ¿Cómo son los desplazamientos que produce el uso de las nuevas tecnologías?

¿Es aplicable el concepto de mirada?

¿Qué efectos son esperables en la asignación de un punto de vista mecánico? (por ejemplo los cascos de inmersión en la realidad virtual).

En general las visiones positivas (esto ya lo hemos desarrollado) nos hablan de democratización en el proceso de construcción significante, permutación de los roles autor/espectador, escritor/lector, etc.

Si hablamos de hipertexto, sabemos de algo abierto, e incompleto. Las interconexiones establecen nexos, expanden instantáneamente un texto al proporcionar grandes cantidades de puntos de amarre donde el lector puede atar otros textos.

Según esto, aparentemente, el margen sería constitutivo del hipertexto: se nutre del mismo diluyendo la noción de centro, en esencia el hipertexto estaría planteando en su relación con el lector una estrategia para su posicionamiento.

En sus análisis pioneros, Vannebar Bush, nos habla de sus deseos de sustituir los esquemas lineales por máquinas poéticas hacedoras de analogías y asociación, la aparente anarquía sobre la que se estructura la imaginación humana es la posibilidad de superar la alienación. Las nuevas herramientas dejarían entonces de ser aquellas generadoras de alienación maquinista y se vislumbrarían otros Tiempos Modernos con Chaplin liberado, provisto de un casco de inmersión de realidad virtual adaptado a su irremplazable bombin negro. 
Diferente es la visión de Comolli (2002), para quien la intervención de la máquina no debe ser emulación del mecanismo asociativo y de inferencias de la mente humana en desplazamiento de la misma, sino un instrumento que descentre y centre la subjetividad del espectador en su relación con el espacio y tiempo representado como una estrategia para producir su intervención, su identificación. El valorizar la mirada como mecanismo que posibilita una expresión artística humanizada es lo que trae las principales dudas sobre una visión positiva del fenómeno de la interactividad.

No puede dejar de llamar la atención la idea de que gran parte de la producción audiovisual en la red responde a una estructura interactiva que involucra al espectador-lector mediante la estrategia del videojuego. Argumento, espectáculo, desarrollo y participación adoptan una forma de interactividad de "elecciones ofrecidas" para un jugador y/o candidato (ganador, perdedor). Cada vez menos espectador.

"...la interactividad asegura el control del centro sobre la periferia, es preciso ver el límite (económico) del poder de cálculo movilizado por estos programas. No sin antes poner de manifiesto el efecto de su presión ideológica, cuya meta es deshacerse del complejo laberinto de identificaciones y proyecciones del cineespectador, siempre reversibles, aleatorias, ambivalentes, polimorfas, inestables, entrópicas. Ganancia de productividad = pérdida para el sujeto." (Comolli, 2002:91)

De esta manera se nos plantea la dicotomía "lógica de la Información" versus "lógica de la transformación". La lógica de la información nos sumerge en el saber más de lo que estamos presenciando. Por eso se apuesta a materializar mundos nuevos, cibermundos en donde la última tecnología nos puede hacer ver, hacer oler, sentir la aspereza, hacer estallar nuestra percepción en una súper envolvente pansensorial efectista.

La lógica de la transformación es "saber de otro modo", por eso la exaltación de las posibilidades de establecer para el espectador "una mirada" un punto de vista que propicie recorrer sin brújula un espacio, con información retaceada, 
ocultada, "es su falta (falta de información) lo que produce efecto (lo que produce lenguaje)"

Y esta tal vez sea otra de las maneras que podemos expresar la dicotomía información-transformación. El esquema estimulo- respuesta aparece como principal formula de la interacción.

La idea de experiencia se le contrapone. La experiencia que surge como consecuencia de habitar un texto no mecánicamente, sino en la experiencia, en una experimentación que nos involucre más profundamente.

¿De que manera además de materializar los cuerpos, podremos simbolizar la mirada?

"Esta cuestión de la experiencia aparece actualmente como central. Porque la experiencia incomoda a los mercados. Desgasta a los consumidores (los educa). Molesta por naturaleza, fatiga a los adoradores de perpetuas novedades. La imperceptible, pero implacable, ley de las sociedades de espectáculos comerciales, reduce el papel de la experiencia (no de la que se vende o consume sino de la que se transmite o intercambia) y de paso reduce el margen subjetivo de toda relación." (Comolli, 2002:92) 
$-5-$

APLICACIÓN DEL MODELO

LECTOR-ESCRITOR AUDIOVISUAL 


\subsection{Introducción}

Nos resulta mas que sugerente encabezar este capítulo haciendo referencia a un texto de J. L. Borges, su figura autoral tiene el atractivo de sintetizar ese modelo que nos proponemos ensayar. En la aplicación y análisis de nuestro objeto de estudio, la figura de lector y escritor (audiovisual) convergen, coinciden. En El Poema de los dones, Borges nos vuelve a sumergir en un mundo de libros ancestrales, personajes en ficciones dentro de ficciones, esquemas concéntricos que le permiten al autor plantear esta particular visión: escritores que son leídos dan paso a lectores que son escritos, revisemos entonces el citado poema:

De hambre y de sed (narra una historia griega)

Muere un rey entre fuentes y jardines;

Yo fatigo sin rumbo los confines

De esta alta y honda biblioteca ciega.

Al errar por las lentas galerías

Suelo sentir con vago horror sagrado

Que soy el otro, el muerto, que habrá dado

Los mismos pasos en los mismos días.

¿Cuál de los dos escribe este poema

De un yo plural y de una sola sombra?

¿Qué importa la palabra que me nombra

Si es indiviso y uno el anatema?

(Borges, 2001:162)

Ser autor (literario) implica necesariamente para Borges el ejercicio de la escritura sustentado en la lectura. Podemos decir que Borges ies un gran lector?, ¿o escritor?, o buscar un término medio y llamarlo imprudentemente un comentador (y sí que lo es).

Borges es paradigmático, su ejercicio de lectura esta expuesta, es parte, de su propia escritura. Poemas, ensayos y ficciones son exposición de su esencia como autor literario. Ser escritor es por sobre todo ser lector. 
Y es así que según el poema, antes que las bibliotecas, existió un jardín laberíntico, y antes de un Borges ciego vagando entre estanterías existió un rey perdido en ese laberinto de jardines y fuentes. Pero por sobre todo esto, antes del poema de J. L. Borges existió una insondable narración griega. Lectura previa y germen.

\subsection{Aplicación del modelo lectura/escritura}

El marco teórico desarrollado hasta aquí nos sirve para llevar adelante el análisis de los productos audiovisuales de los 153 alumnos observados.

La producción total de los mismos fue de 37 cortometrajes de ficción realizados en video. Como ya se comentó las pautas para la realización fueron los bastantes amplias como para permitir incrustaciones de tipo documentaltestimonial o de género, permitiendo también distintas estructuras narrativas y formales estéticas (televisiva, cinematográfica, experimental, vídeo clip). Es importante señalar también que no hubo ninguna presentación que hiciera uso de una estructura hipertextual de ficción a pesar de ser un soporte de texto audiovisual permitido por la cátedra como ejercitación final.

A esta altura vale la pena recordar cuales fueron las condiciones de aplicación del modelo de interpretación lectura-escritura de imágenes. 


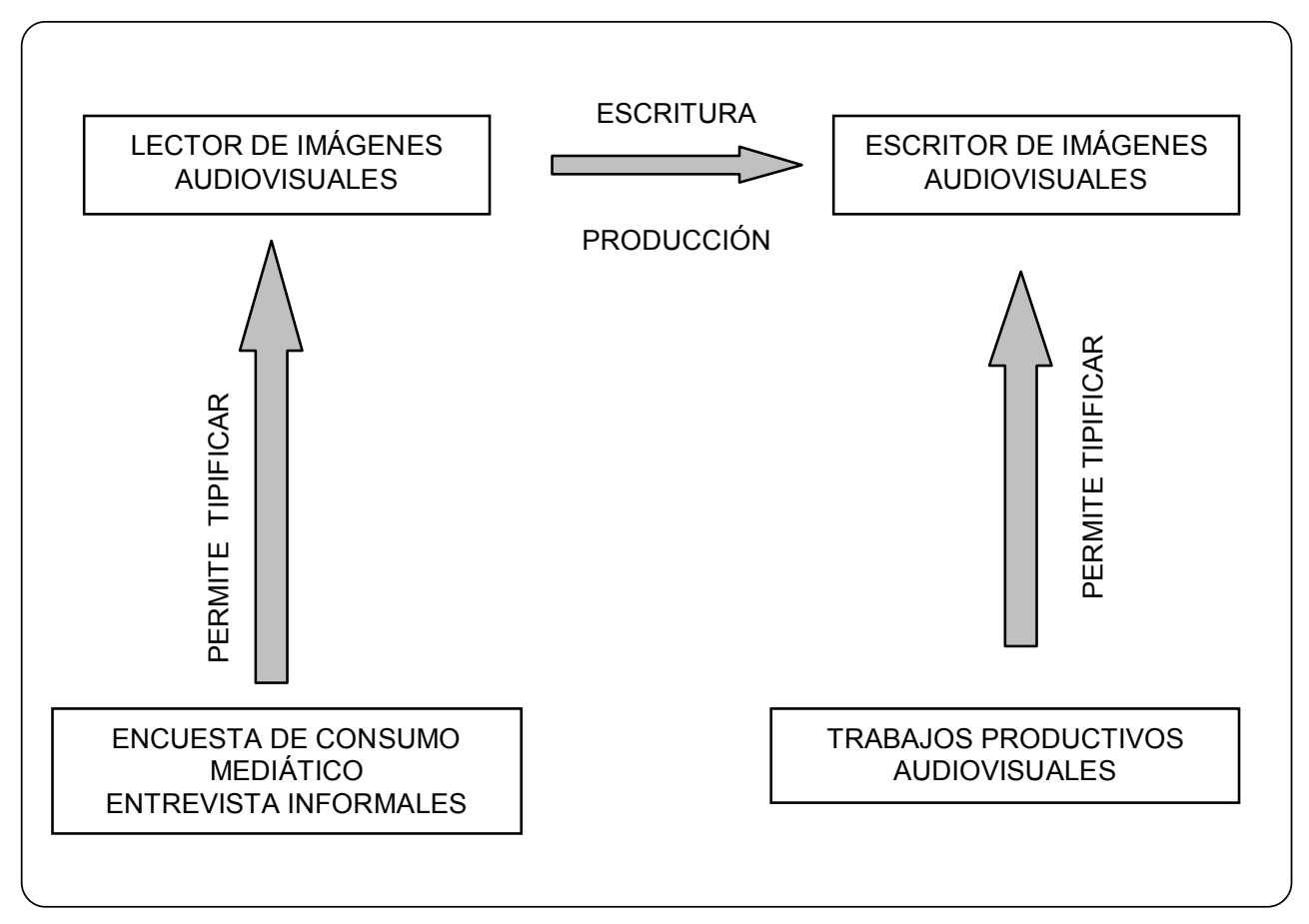

\subsection{El Escritor Audiovisual}

\subsubsection{Los Textos Audiovisuales. Tipologías}

Lo hasta aquí desarrollado nos permitirá plantear en la aplicación del modelo lectura-escritura de los textos audiovisuales observados, una grilla de análisis fundada en la definición de tipologías. Estas tipologías surgen estrictamente de las características del material de análisis.

Pero antes de esto es necesario aclarar que la complejidad de las incidencias de las nuevas tecnologías en los textos audiovisuales se traduce fundamentalmente, como lo hemos ido planteando en nuestro marco teórico, en una revisión, en una re-velación, de formas audiovisuales preexistentes.

Por esto es que hablamos fundamentalmente de incidencias (y no solo de nuevas formas audiovisuales). Evidentemente ha habido una vuelta a formas de representar que ya el cine en sus orígenes había experimentado. 
Salt (1992) señala el período 1895-1900 como el de uso inicial de la viñeta, el período 1900-1906 como aquel en donde se instala el uso del coloreado por sectores de pantalla, el recurso de alterar la velocidad de las imágenes (ralenti, cámara rápida) y la pantalla partida (split screen). Asimismo el lapso que comprende 1920-1926 es aquel en que se instala el uso de lentes anamórficos y sobreimpresión múltiple (Salt 1992: 35, 44, 48, 57, 166, 175).

Todos estos recursos, vemos, ya formaban parte de la historia del cinematógrafo, habían sido no solo un antecedente de la implementación de una imagen experimental, sino puntales en la conformación de un lenguaje de imágenes en movimiento.

Sin embargo, como ya lo hemos analizado, las formas audiovisuales terminaron respondiendo hegemónicamente a un modelo de transparencia necesariamente opuesto a todos estos recursos que hemos enumerado.

La irrupción de la imagen electrónica (video y televisión) provocó una vuelta a ciertas formas. La incorporación de la tecnología digital en la captura y/o procesado de la imagen también tuvo sus consecuencias directas.

Y no solo hay un reciclaje de formas marginales a la transparencia de la institución cinematográfica, también se incorporan nuevas formas emergentes de las posibilidades del hipertexto, con importantísimas consecuencias a nivel estructuración del espacio, del tiempo, de la estructura narrativa.

Representación y estructura son entonces básicamente los dos puntales sobre los que plantearemos nuestra grilla evaluativa.

Para tipificar los textos audiovisuales se enumeraron entonces los siguientes recursos formales.

Tipología 1. Recursos de Representación. 
Fueron consideradas como incidencias de las nuevas tecnologías en las formas de representación:

- la electrificación (visual o sonora),

- la pictorización de la imagen, o cualquier tipo de modificación del registro mimético de la imagen videofilmográfica por técnicas que pueden ser la aplicación de filtros audiovisuales normalizados en software de tratamiento de imagen o por procedimientos más artesanales, generalmente representación de la representación, (filmar de pantalla de monitor, grabar de pantalla de monitor, etc.).

Es interesante señalar aquí que estas técnicas se corresponden con un tratamiento de "degradación" de la imagen debido a la modificación que se produce en la copia por efecto de tecnología analógica. Lo que sucede en la imagen cuando se filma de pantalla (barrido, perdida o saturación o viraje del color) puede ser tipificado como un copiado analógico (no existe un código binario digital que transfiera la información garantizando la clonación o copia perfecta).

- Son también considerados dentro de este apartado los tratamientos de imagen logrados a partir de la deformación espacial y temporal (aplicación de filtros deformantes, ralenti, efecto estroboscópico, still, etc.). Estos efectos son considerados, a pesar de haber sido empleados por el cinematógrafo a partir de técnicas específicas (laboratorio y revelados, uso de lentes deformantes durante la filmación), pues como ya hemos explicado (capítulo La nueva imagen) su generalización y uso son consecuencia directa de la electrificación de la imagen.

\section{Tipología 2. Recursos de Estructura}

Dentro de este tipo son consideradas las incidencias a nivel estructura. En concreto las formas en que se estructura el espacio y el tiempo. En contraposición con un esquema aristotélico podemos puntualizar: 
- la iteración, repetición, serialidad (en convergencia o divergencia) de los distintos elementos que conforman un espacio o tiempo.

- La bifurcación, entrelazamiento, o emulación de acceso a lectura aleatoria (se habla de emulación pues como ya se ha señalado no hay entre los trabajos analizados ningún hipertexto)

\section{Tipología 3. Recursos de Montaje en Pantalla}

Se hace necesario distinguir el collage o montaje en pantalla, procedimiento que pone de alguna manera en juego la combinación de lo especificado en los apartados anteriores. El collage implica una estructuración espacial y/o temporal y al mismo tiempo una operación de construcción de una nueva imagen a partir de las imágenes montadas en la totalidad del cuadro. También podemos señalar que a pesar de ser un procedimiento ya usado por el cine, su uso se ve afectado por las nuevas tecnologías en la posproducción de imágenes. 


\subsubsection{Resultados}

Según estas premisas se revisaron entonces los 37 cortometrajes de ficción. El procesamiento de los datos recopilados arroja los siguientes resultados:

Del total un porcentaje del 32 por ciento ha hecho uso de por lo menos alguno de estos recursos. Los recursos de representación han sido los más utilizados (24 por ciento), el número baja visiblemente si consideramos aquellos trabajos que han hecho uso de recursos de montaje (16 por ciento) y aun más si consideramos aquellos que han utilizado recursos de estructura (5 por ciento). Ver gráfico 13.

Si discriminamos cada tipología puesta en juego en cada producción en particular identificando que tipo de resolución es aplicada observamos que solo un trabajo de los 37 recurre a los tres recursos (representación, estructura y montaje en pantalla). El mayor porcentaje se da para trabajos que recurren solo a recursos de representación (13,5 por ciento). Se nota nuevamente que los porcentajes más bajos son aquellos en los cuales está involucrada como forma la tipología 2, relativa a formas novedosas de articular el espacio-tiempo. Ver gráfico 14.

Sintetizando, los recursos de representación han sido los más utilizados, el número baja visiblemente si consideramos aquellos trabajos que han hecho uso de recursos de montaje y aun más si consideramos aquellos que han utilizado recursos de estructura. 


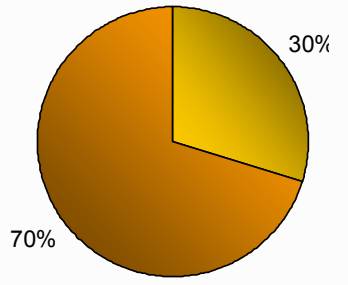

$\square$ se observa por lo menos uno de los recursos

$\square$ no se observan ninguno de los recursos

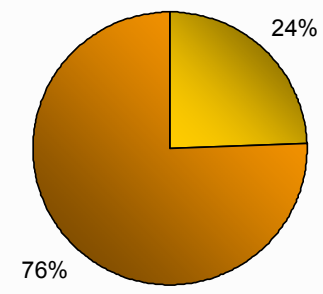

$\square$ se observan recursos en la representación

$\square$ no se observan recursos en la representación

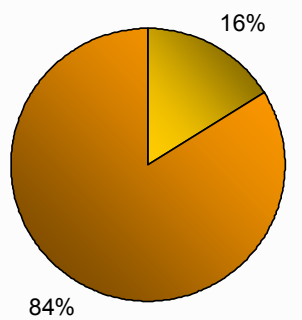

$\square$ se observan recursos en el montaje

$\square$ no se observan recursos en el montaje

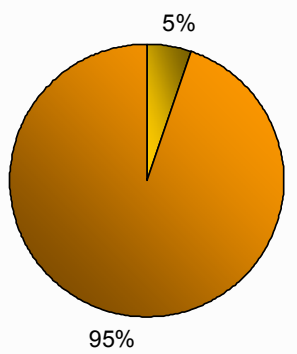

$\square$ se observan recursos en la estructura

$\square$ no se observan recursos en la estructura 


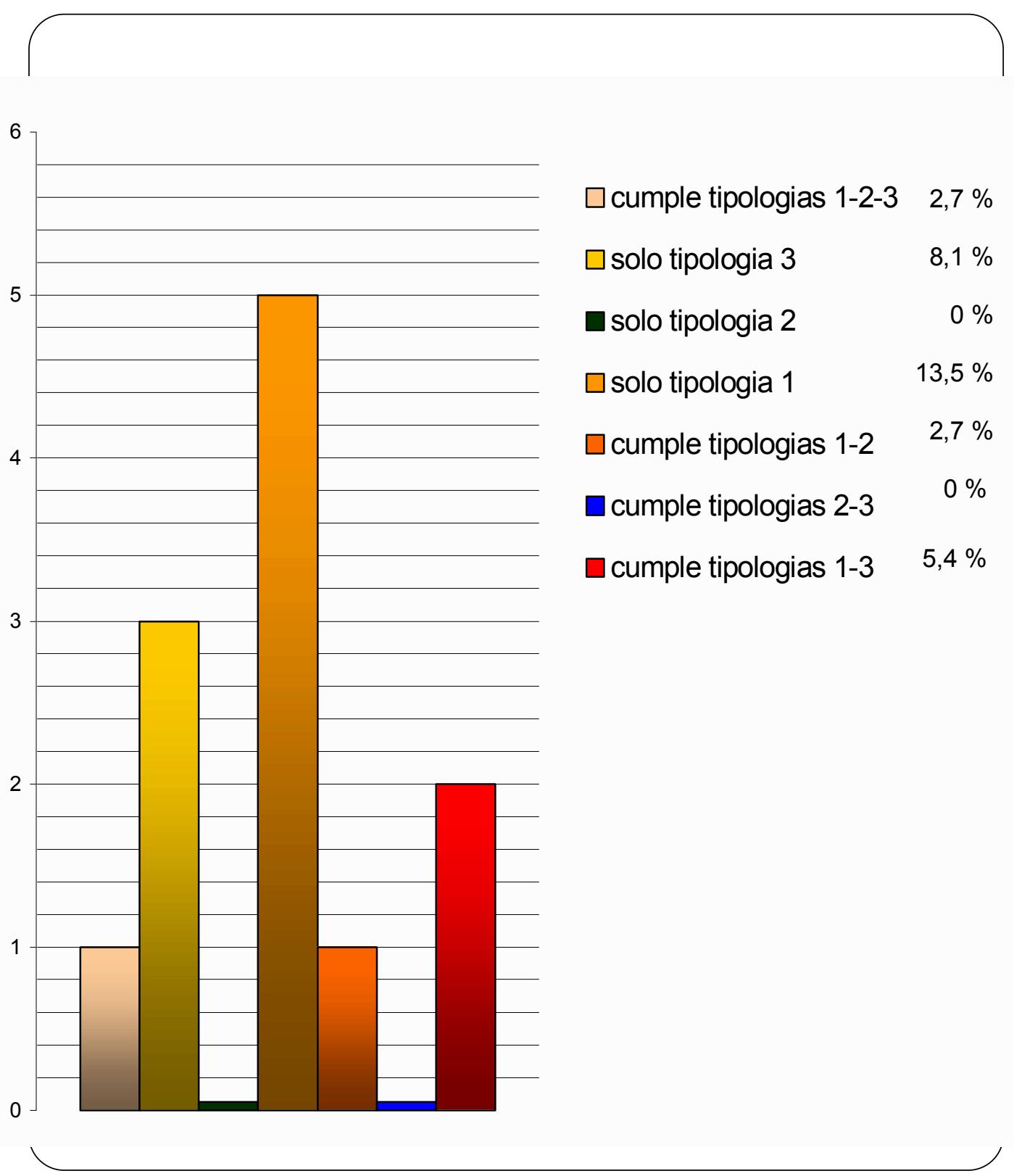


Avanzando en el análisis se confeccionó una subclasificación que surge del material en sí (la subclasificación no intenta ser exhaustiva y general sino particular al material analizado). En la subclasificación que surge en el apartado representación observamos una predominancia de los recursos de pictorización, este tratamiento de la imagen es realizado a partir del uso de filtros normatizados de algún software de tratamiento de imagen (gráficos 15 y 16). Son menos los casos que recurren a técnicas más artesanales (representar lo representado) grabando o filmando del monitor como una manera de electrificar la imagen.

El caso que se señala en combinación-otros se corresponde con la integración de efectos de alteración del parámetro temporal y espacial (ralenti estroboscópico - y filtros de posproducción deformantes). Ver cuadro 1.

Cuadro 1 - Recursos representación - Subclasificación

\begin{tabular}{|c|c|}
\hline Pictorización & 6 casos \\
\hline Electrificación & 2 casos \\
\hline Combinación - otros & 1 caso \\
\hline
\end{tabular}

\begin{tabular}{|c|c|}
\hline Total con recursos de representación & 9 casos \\
\hline Total observados & 37 casos \\
\hline
\end{tabular}

Los gráficos 15 y 16 se presentan como ejemplos de material observado que responden a la clasificación anterior. El ejemplo del gráfico 15 tiene la particularidad de ser un tratamiento de electrificación de la imagen mediante la técnica de grabación de pantalla. Se pone en evidencia en este caso lo electrónico del medio a través del barrido que se produce en la imagen debido al asincronismo entre imagen en pantalla y el medio de registro. Además la técnica (reproducción de reproducción, imagen de imagen) produce cierta alteración y saturación de los colores. Es importante para nosotros distinguir 
este caso del de la figura 16, no tanto por los resultados sino por la técnica puesta en juego en el proceso de alteración de la imagen. En este caso dicha alteración se produce por la aplicación de filtros que modifican la característica de la imagen desde la plataforma digital de uso en la posproducción.

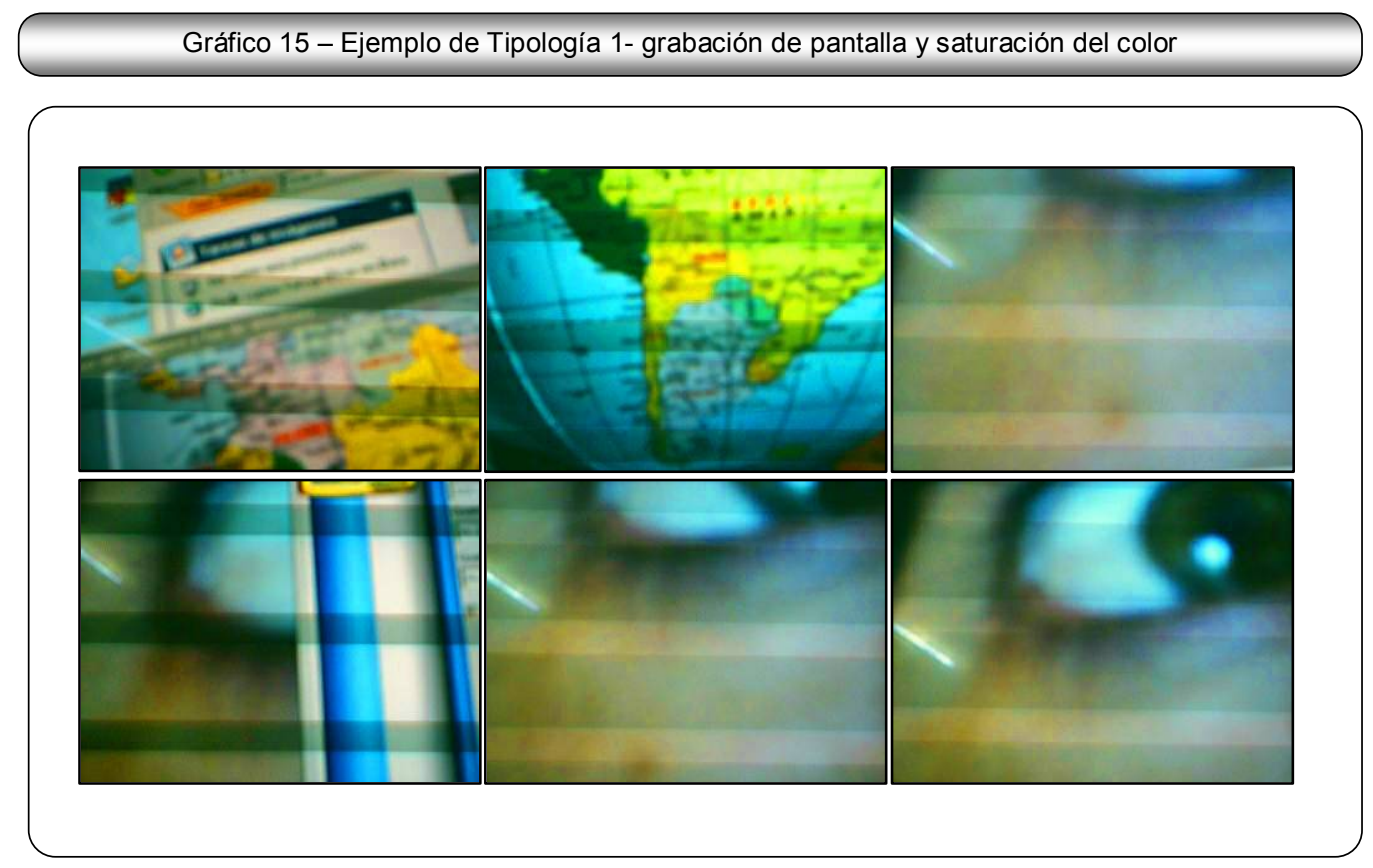

Gráfico 16 - Ejemplo de Tipología 1- viraje y saturación de color, aplicación de filtros

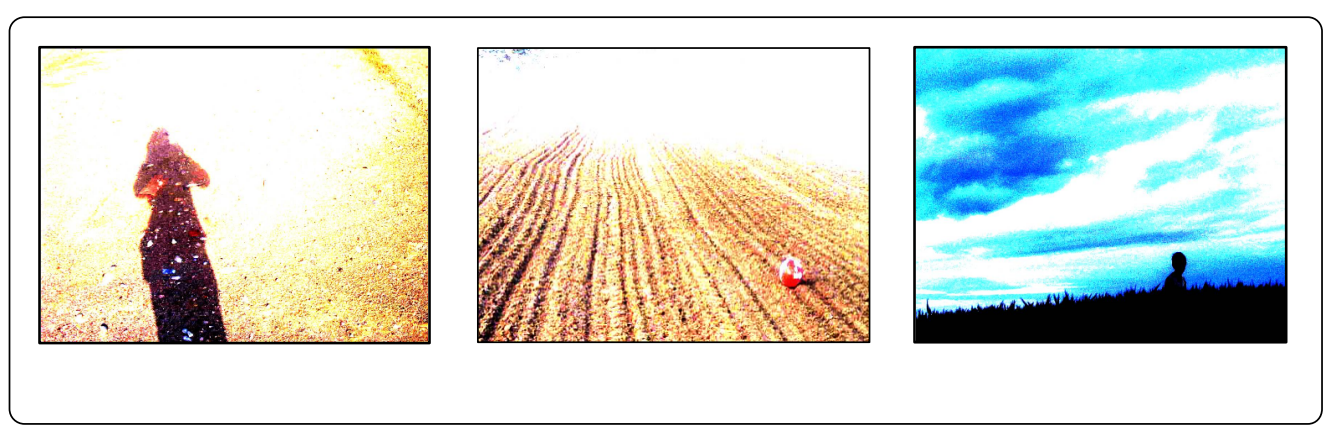

Realizando la misma observación para la tipología de montaje en pantalla podemos señalar que según el material analizado se pudo establecer una subclasificación acorde. Dicha subclasificación, contrariamente a lo observado 
para los recursos de representación, revela cierta homogeneidad en la cantidad de casos para cada resolución.

Cuadro 2 - Recursos de montaje - Subclasificación

\begin{tabular}{|c|c|}
\hline Pantalla partida (split screen). Montaje paralelo & 2 casos \\
\hline Pantalla partida (split screen). Montaje dialéctico & 1 caso \\
\hline Collage gráfico. Sectorización cromática & 2 casos \\
\hline Sobreimpresión continua & 1 caso \\
\hline
\end{tabular}

\begin{tabular}{|c|c|}
\hline Total con recursos de montaje & 6 casos \\
\hline Total observados & 37 casos \\
\hline
\end{tabular}


Los casos de pantalla partida (recurso proveniente del lenguaje audiovisual televisivo y que tiene en la cinematografía algunos raros casos) es usado como montaje paralelo (para describir dos acciones simultaneas) y como montaje dialéctico (haciendo coexistir en cada sector de la pantalla dos imágenes que en una dialéctica de su contenido generan un tercer sentido).

El uso de gráfica (texto sobreimpreso) como recurso técnico-expresivo es considerado junto con un caso de sectorización cromática: mediante el uso de filtros por sectores de pantalla se colorea un objeto dejando en blanco y negro lo restante.

Finalmente la sobreimpresión continua (dos o más imágenes que permanecen diluidas, fundidas sin que una prevalezca sobre la otra). Ver gráficos 17,18 y 19. 


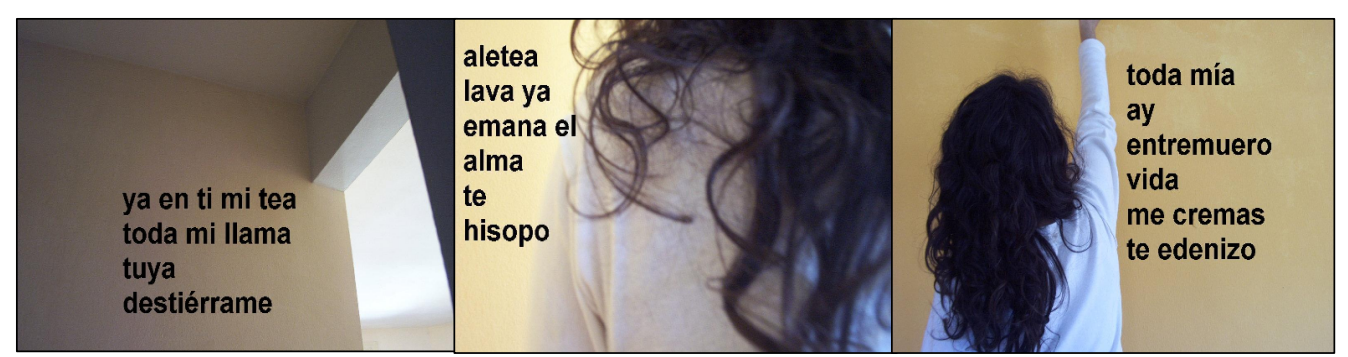

Gráfico 18 - Ejemplo de Tipología 3 - pantalla partida-picture in picture



Gráfico 19 - Ejemplo de Tipología 3 - sectorización cromática
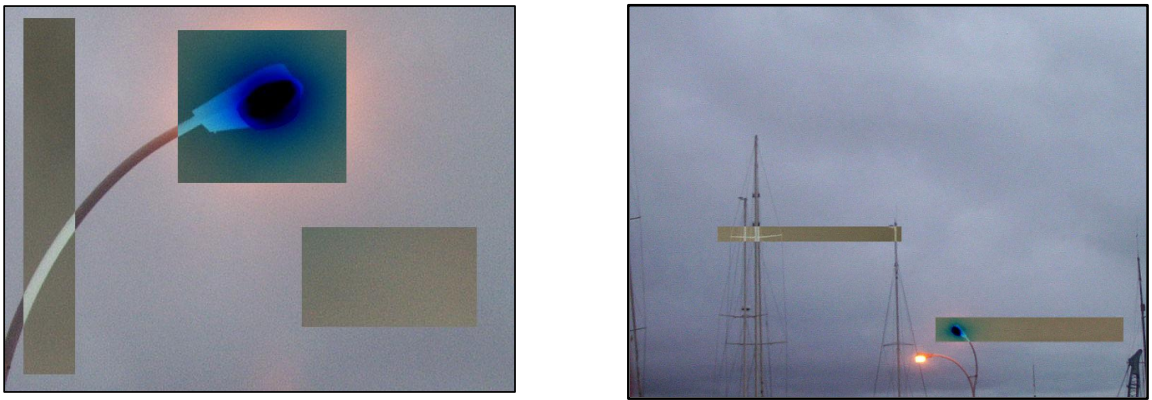
Por ultimo también se realiza una subclasificación en los recursos de estructura. Se distinguen dos casos bien diferenciados: por un lado los procesos de iteración, o repetición que actúan a nivel narrativo generando estructuras cíclicas (for next narrativos), podríamos diferenciar dos casos del mismo y serían aquellas iteraciones que actúan a nivel macro (repetición de un plano o grupo de planos) o micro (por ejemplo avances y retrocesos sobre una acción determinada) ambas características se encuentran en un mismo trabajo.

También corresponden a esta tipología los casos de bifurcación narrativa que asumen el esquema de simulación de lectura hipertextual de elección de opciones.

Cuadro 3 - Recursos de estructura - Subclasificación

\begin{tabular}{|c|c|}
\hline Iteración - serialidad - repetición (visual y sonora) & 1 caso \\
\hline bifurcación & 1 caso \\
\hline
\end{tabular}

\begin{tabular}{|c|c|}
\hline Total con recursos de estructura & 2 casos \\
\hline Total observados & 37 casos \\
\hline
\end{tabular}

Todo esto se complementó con los elementos que surgieron en el proceso de evaluación explicado en el apartado El Proceso Pedagógico como así también de aplicar todos los elementos (propuesta estética, cuaderno de bitácora) que sirvieron en la evaluación del proceso completo de construcción del texto audiovisual. 


\subsubsection{Análisis de dos modelos audiovisuales}

Lo expuesto hasta aquí en lo que a formas audiovisuales se refiere nos permite plantearnos con fines pedagógico-expositivos dos esquemas absolutamente radicales. Podríamos imaginarnos dos paradigmas audiovisuales de manera que cada uno representara esquemáticamente lo que venimos sosteniendo como modelos opuestos. Lineal versus no lineal, analógico versus digital, son dicotomías que venimos señalando como pertenecientes a formas de representar que se corresponden lógicamente asociadas a las nuevas tecnologías involucradas en los procesos de producción audiovisual. Lo anterior podríamos sintetizarlo según dos modelos.

Un primer modelo, que llamaremos modelo $A$ tendría las características de forma audiovisual con las mayores influencias de las nuevas tecnologías. Y por lo tanto presentaría una preponderancia de formas audiovisuales que se corresponden con las tres tipologías detalladas.

El segundo modelo, que llamaremos modelo $B$ tendría las características de forma audiovisual que responde a maneras clásicas de estructurar y de representar. $Y$ por lo tanto no presentaría formas audiovisuales que se corresponden con las tres tipologías detalladas.

Ambos modelos esquematizados tienen para nosotros existencia dentro del material audiovisual analizado perteneciente a la producción audiovisual de la Universidad Nacional de La Plata.

Se expone entonces el análisis de dos cortometrajes que por sus características adquieren el carácter de ejemplificadores de los modelos expuestos anteriormente.

Se corresponde con el modelo A el cortometraje Sin Título (Khourian 1999). El mismo es un trabajo realizado por alumnos de la actual carrera de Comunicación Audiovisual de la UNLP. Realizado en video ( $\mathrm{vhs}$, blanco y negro). El tema tratado es una intervención quirúrgica de parto (cesárea). El texto audiovisual se presenta como el más extremo en la aplicación de los recursos formales (representación, montaje en pantalla y estructura), en este 
sentido es ejemplificador de nuestro análisis formal además de pertenecer al grupo de los textos audiovisuales observados.

El otro trabajo que analizaremos, y que se corresponde con el modelo $B$, será Cirugía (Vesco 1960). Los alumnos autores de Sin Título conocieron y estudiaron el cortometraje Cirugía como parte de los prácticos del seminario de mediateca. El reconocimiento por parte de este grupo a un material producido en el mismo ámbito institucional casi 40 años antes culminó en Sin Título. (Ver Anexo $\mathrm{cd}$ rom con análisis interactivo).

El cortometraje Cirugía (Vesco 1960) es un trabajo realizado por alumnos de la antigua carrera de cinematografía que funcionaba en la UNLP. Realizado en fílmico (16 mm., blanco y negro) su origen responde a un pedido del Ministerio de Salud de la Pcia. de Buenos Aires. Con un concepto que hoy podríamos denominar como divulgación científica. El tema tratado es una operación de apendicitis.

A nosotros nos interesa presentar el análisis de este material pues representa el paradigma opuesto a Sin Título (clasicidad en la estructuración del espacio tiempo, uso tradicional del recurso mirada, etc.). A pesar de no pertenecer al material textual audiovisual observado, su análisis como material anexo a Sin Título resulta pedagógico para nuestra exposición, fundamentalmente por ficcionalizar el mismo hecho documentado audiovisualmente (una intervención quirúrgica).

Ambos trabajos presentan la particularidad de que a pesar de ser sus imágenes un registro documental, en su forma final audiovisual son producciones de ficción puras. En el análisis nos referiremos a la forma en que los acontecimientos son organizados en los parámetros espacio y tiempo. Esto nos permitirá visualizar su estructura. También nos resulta apropiado revisar que modos de representación audiovisual son adoptados en cada uno de los trabajos. 


\section{Análisis del modelo A}

La forma en que se organiza el tiempo en Sin Título es mediante la iteración, la repetición y modulación-variación. Se detiene en momentos seleccionados (el del alumbramiento, el del corte, el de la manipulación, etc.). El instante se estanca. Avanza y retrocede sobre la iteración. Cada uno de estos elementos (momentos de repetición) es desplegado en la estructura general del trabajo.

Los ritmos se definen por niveles: un loop sobre la acción (de avance, de retroceso o de permanencia), y un juego permutativo de los elementos de repetición.

El espacio se organiza mediante el recurso de las repeticiones que además concentran y afirman el campo. La banda sonora (monitoreo, maquinaria médica, respiración etc.) refiere a objetos fuera de campo, sin embargo el tratamiento lo asocia directamente a la imagen campo. La desestructuración en lo temporal, desarticula también el espacio. Veremos que en el trabajo Cirugía la planificación tan cerrada (en planos detalle) garantizaba un espacio fílmico estructurado gracias a la linealidad del flujo temporal y a la apertura y cierre del trabajo con dos planos generales (entrada y salida del paciente y enfermero).

En lo que respecta a la imagen de Sin Título, mediante la aplicación de filtros, procesos de grabación de pantalla, y quitado de cromatismo se obtiene una imagen electrificada, pixelada, de alto contraste. Aquí, contrariamente a lo que veremos en el trabajo Cirugía, se elige hacer sentir al espectador el artificio, el tratamiento. Este esquema también es aplicable a la banda sonido. La imagen sonora es electrificada, se modula, se repite. Vemos que Sin Título (gráfico 20) se estructura en módulos que no responden a un desarrollo clásico de principio nudo y desenlace estos módulos se repiten en la estructura general con variaciones en la repetición. 


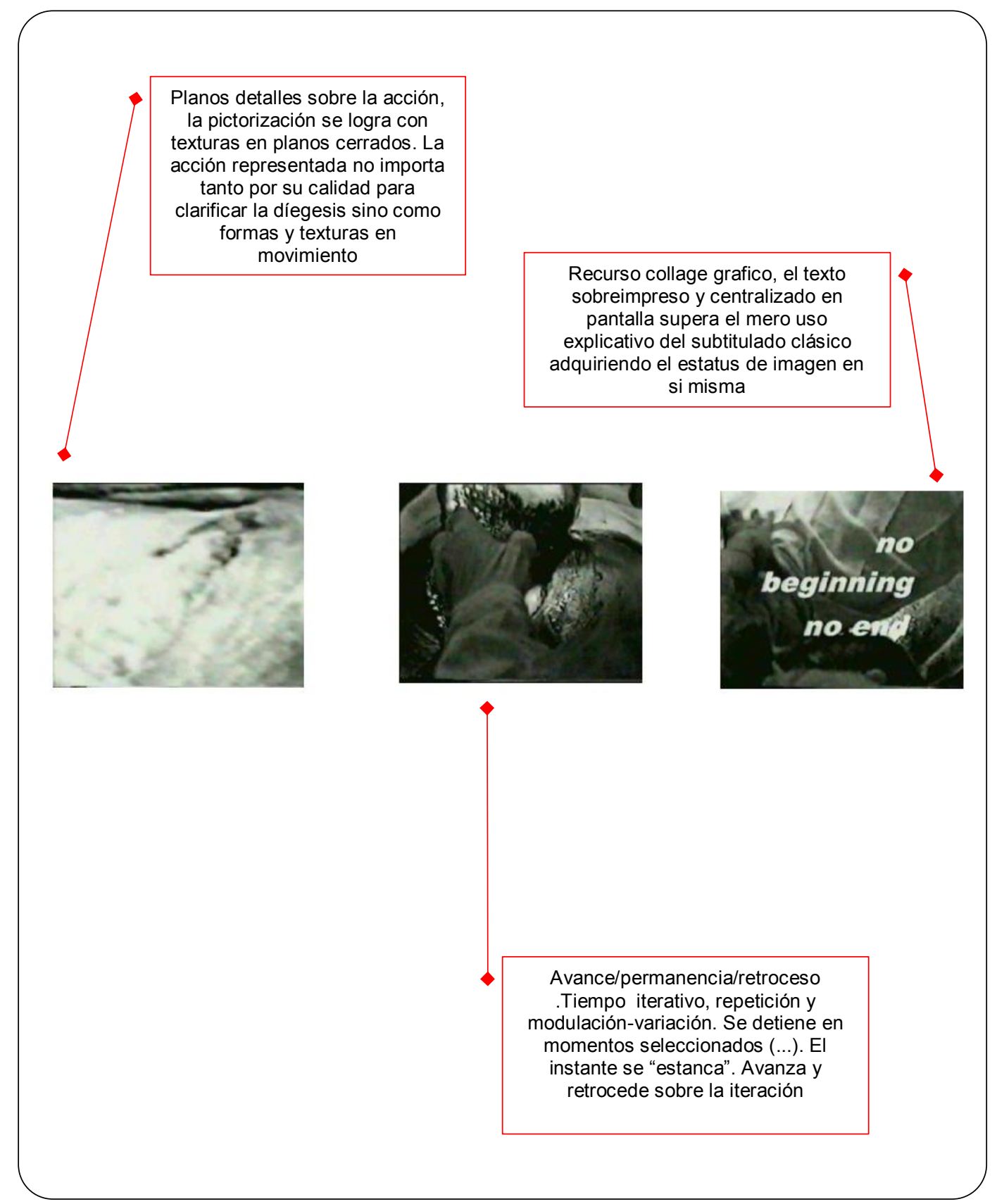


PUNTOS DE ANCLAJE-

CORRESPONDENCIA SONORO VISUAL
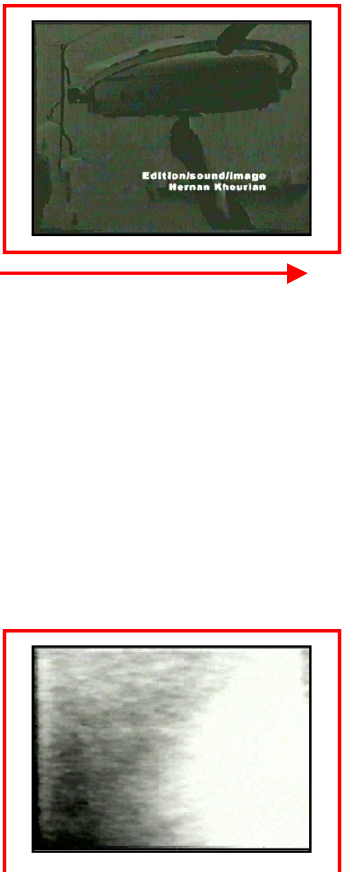

VALORIZACION DE FUERA DE CAMPO
En el inicio el titulo es señalado con un sonido, la entrada de imágenes coincide con el fundido del mismo para dar paso a una mezcla base de sonidos ambiente tratados.

La ausencia de formas en campo plantea un espacio vacío que valoriza el fuera de campo amplificado por el recurso sonoro.
Hacia el final el desvanecimiento de la imagen visual se corresponde con el sonido, rítmicamente también se plantea una semejanza, lo visto y lo escuchado igualan en la cadencia de una oscilación/fluctuación 


\section{Análisis del modelo B}

En el trabajo Cirugía el tiempo es lineal, organizado secuencialmente en el sentido del fluir de los acontecimientos representados. La existencia de elipsis temporales responde a un criterio funcional y operativo. (Dramatizante a veces: la mirada de la espera de la paciente). Ver CD interactivo adjuntado.

El espacio se estructura con claridad, de forma clásica, ordenado según un punto de vista asignable a un espectador privilegiado que se despliega en la mirada de la paciente y del equipo médico. Solo en la entrada y salida del quirófano (inicio y fin del cortometraje) se establece el escenario mediante planos generales (planos de establecimiento). El resto son planos más cerrados (detalles) que tienen como eje la acción. La planificación responde a un criterio de análisis de las acciones. Se define claramente el acontecimiento dramático. La planificación de planos detalle, como así también la riqueza y diseño de la banda sonora, realzan la existencia del fuera de campo.

El concepto de la banda sonora responde también a un esquema lineal y representacional.

Claramente se observa un tipo de montaje transparente que apuesta a hacerse invisible para el espectador como recurso, lo que interesa es la lógica del acontecimiento que va señalando el camino a recorrer y la fragmentación y sutura plano a plano.

La imagen visual, a pesar del blanco y negro, no es tocada en el sentido de producir distorsiones o tratamientos en la misma, es una imagen natural, mimética. Se cumpliría en este caso los preceptos de la objetividad de la imagen fotográfica. Ver gráfico 22. 


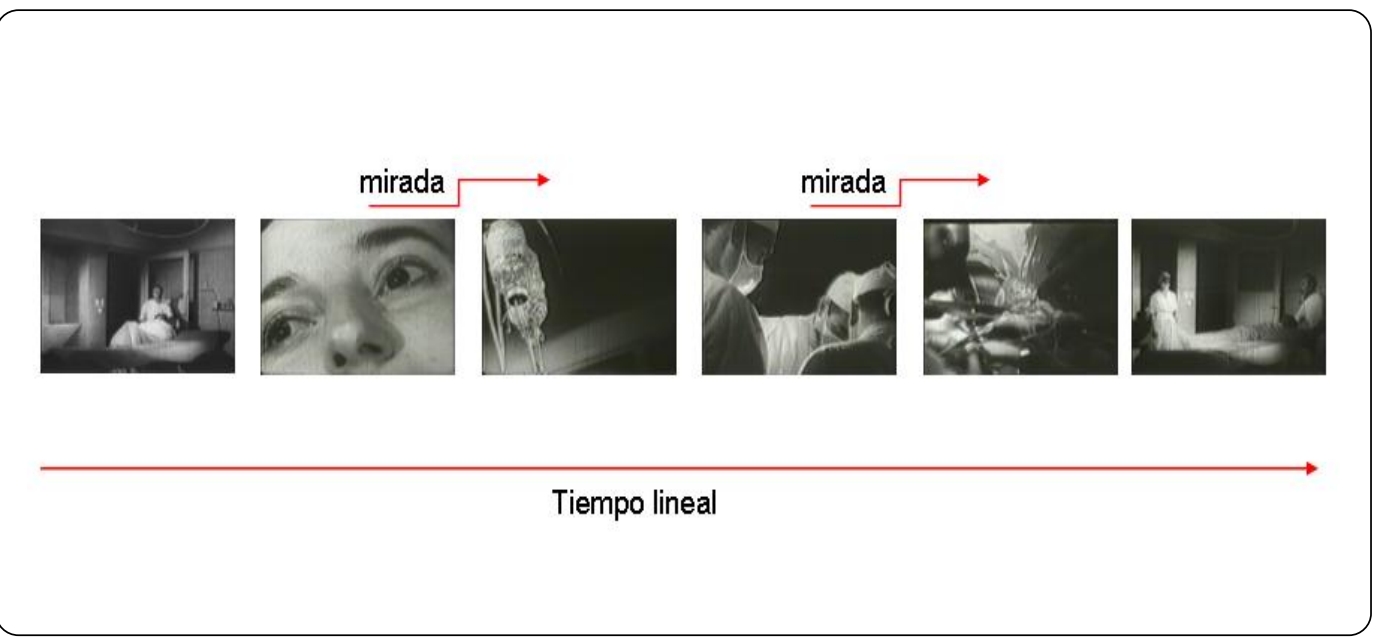

Gráfico 23 -Comienzo-final cortometraje Cirugía

El plano que inicia plantea claramente la situación espacial. Entran en "escena" (teatralmente hablando) los actores de la narración, el plano describe una acción que es comienzo de la intervención quirúrgica, la iluminación (cenital teatral) focaliza y señala el lugar del evento, la austeridad escénica recorta, aísla y subraya.

Idéntico al plano del inicio, solo se agrega la figura de la enfermera con barbijo. La puerta hace nuevamente de bambalinas, la simetría se plantea como esquema de resolución formal de la narración.
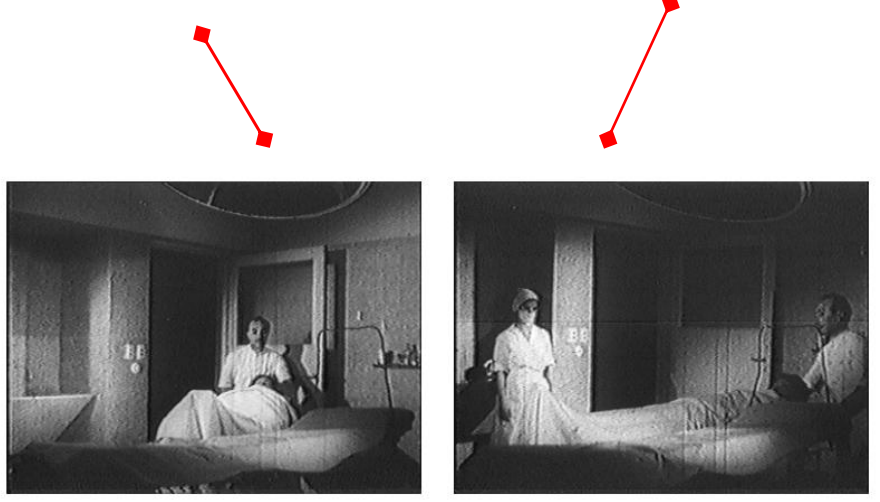

Inicio y final, entrada y salida en plano de situación (plano general). Un principio es aquello que en sí no es necesariamente precedido por otra cosa y que naturalmente tiene algo después. Un fin es aquello que naturalmente viene a continuación de otra cosa, como su consecuencia necesaria o habitualmente; un medio es aquello que por naturaleza esta después de algo y que tiene algo después 
Espacio: claro, clásico, ordenado según un punto de vista asignable a un espectador privilegiado que se despliega en la mirada de la mujer y los médicos, el recurso mirada se transfiere a los distintos actantes
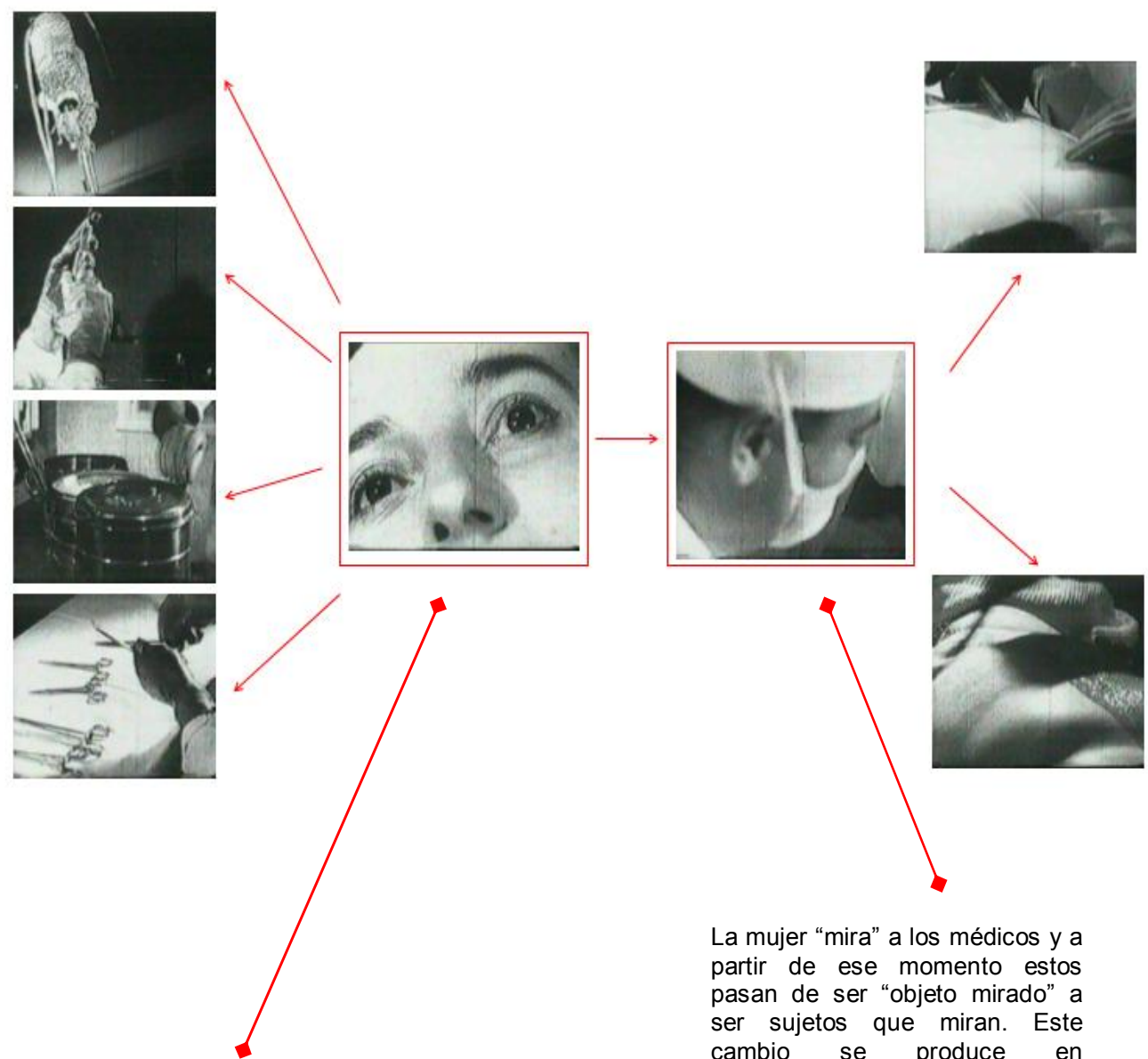

"montar es unir, relacionar a los personajes entre sí y con las cosas a través de la mirada". La mirada de la mujer vehiculiza el primer grupo de planos, los objetos son mirados y esto plantea la unión entre los mismos

La mujer "mira" a los médicos y a partir de ese momento estos pasan de ser "objeto mirado" a ser sujetos que miran. Este cambio se produce en correspondencia con el adormecimiento a causa de la anestesia: alguien deja de mirar, pero se produce el relevo por parte de los médicos. 


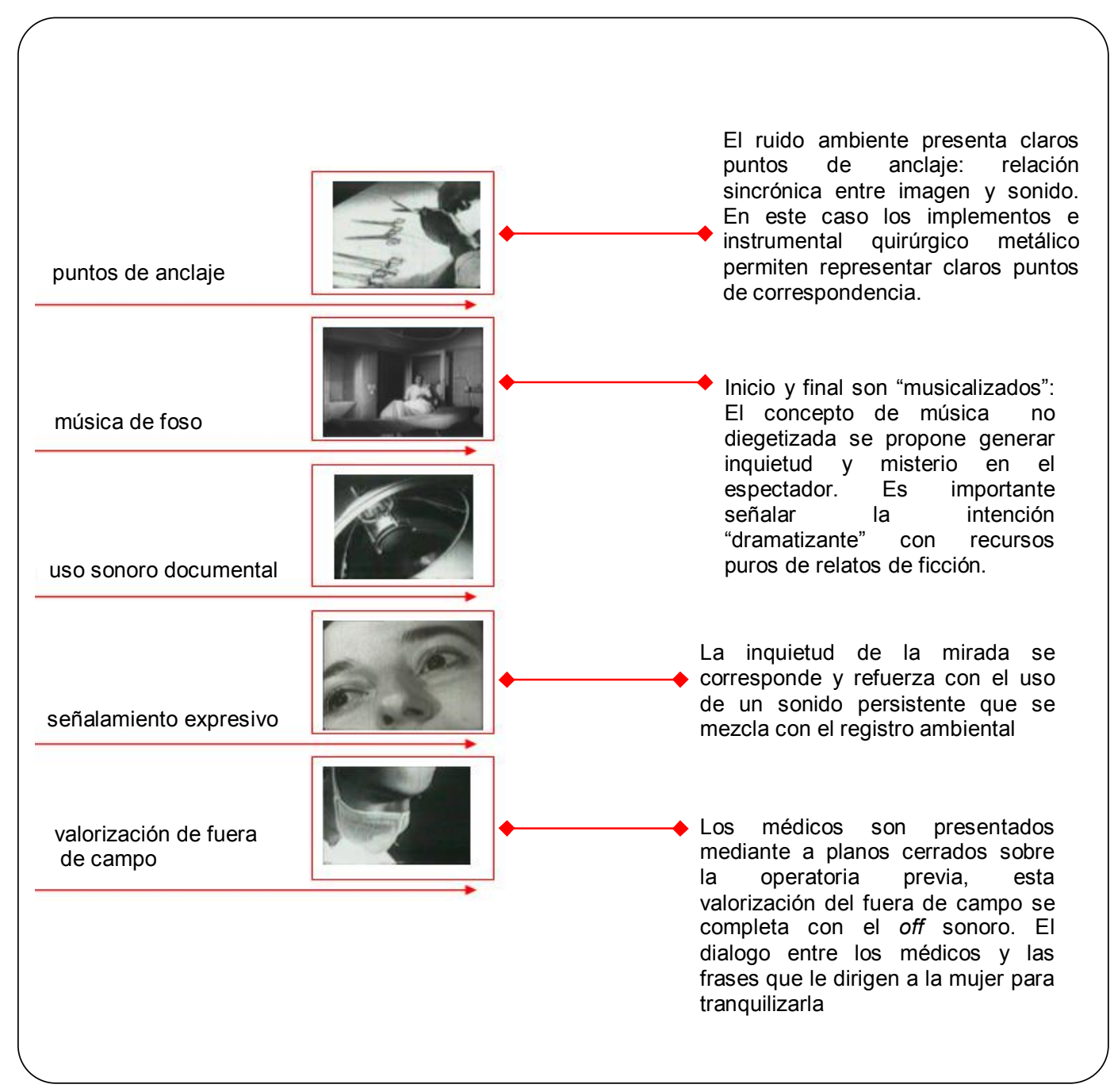




\subsection{El lector audiovisual}

\subsubsection{Determinación de un perfil de consumo mediático}

En el grupo de alumnos ya mencionado se determinó condiciones previas de consumo y preferencias audiovisuales de cada uno de los integrantes de cada grupo. Se exploró y tipificó la existencia de los distintos imaginarios individuales previos. Como herramienta central se desarrolló un sistema de encuestas (ver anexo encuesta consumo mediático) y entrevistas.

El estudio del consumo mediático de cada alumno y de cada grupo conformaron una matriz. Las variables son aquellas que tipifican: consumo de televisión (distinguiendo entre televisión informativa, televisión entretenimiento, televisión educativa etc.), consumo cine, radio, vídeo, informático, medios gráficos, artes escénicos (teatro, danza).

Es importante señalar que en la encuesta de consumo mediático se consideran fundamentales todos los aspectos que se relacionan con nuevas formas de consumir en los medios tradicionales (radio, televisión, etc.).

Es por esto que en el procesamiento de la encuesta se hace especial hincapié en detectar que tipo de ficciones se consumen y como.

Si por ejemplo las ficciones seriales de televisión vistas responden a esquemas clásicos de estructuración espacio temporal, podemos entonces intentar relacionar este aspecto a las formas adoptadas para producir (escribir) audiovisualmente.

Por supuesto también es importante el uso de los ordenadores: detectar qué y de que manera se consume en la red. También fue necesario incrustar en la encuesta de consumo un apartado de preguntas que se refieren al uso de las nuevas tecnologías en el procesamiento de imágenes y sonidos. Estos aspectos son de utilidad para revisar las nuevas herramientas puestas en juego en el proceso productivo. 
Del sistema de encuestas y en complementación con entrevistas informales a alumnos se obtuvieron los siguientes resultados.

\section{Televisión}

La franja mayoritaria (60 por ciento) ve 2-3 horas por día (gráfico 26). Los "adictos a la televisión" (más de 6 horas por día, 5 por ciento) son en número comparable con aquellos que no ven televisión (7 por ciento).

Un perfil medio (gráfico 27) señala la preferencia por las ficciones (el 52 por ciento entre filas, series y series nacionales) y los entretenimientos (el 21 por ciento). Dentro de las ficciones el género de la serie (35 por ciento) supera en más del doble a los films (largometrajes de ficción). Tienen un peso especial las series locales (productos Adrián Suar - Gasoleros - Vulnerables), y las series de importación (Fox, Warner), formato diario o semanal de una hora de duración. Dentro de este tipo se incluyen entregas seriales tipo culebrón, se observa asimismo una integración y síntesis de este género en hibridación con ficciones seriales de acción, comedia-humor etc., esto tanto en el campo productivo televisivo como en la percepción y gusto del espectador.

En largometrajes de ficción (Cinecanal, Fox) también se incluye con un peso especial la cinematografía nacional (Canal Volver). Es de relativa importancia (tal vez esperando un porcentaje mayor debido a lo juvenil de la franja estudiada) el consumo de video clip (un 7 por ciento de audiencia para MTV y Much Music). El aspecto entretenimiento e información corresponde mayoritariamente a televisión de aire. 


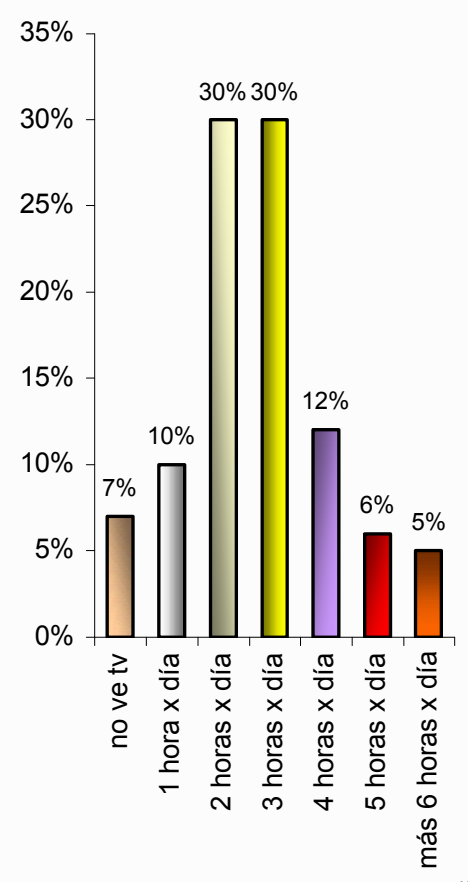

$\square$ no ve tv

$\square 1$ hora $x$ día

$\square 2$ horas $x$ día

$\square 3$ horas $x$ día

$\square 4$ horas $x$ día

$\square 5$ horas $x$ día

$\square$ más 6 horas $x$ día

(*) muestra de 153 alumnos de comunicación audiovisual

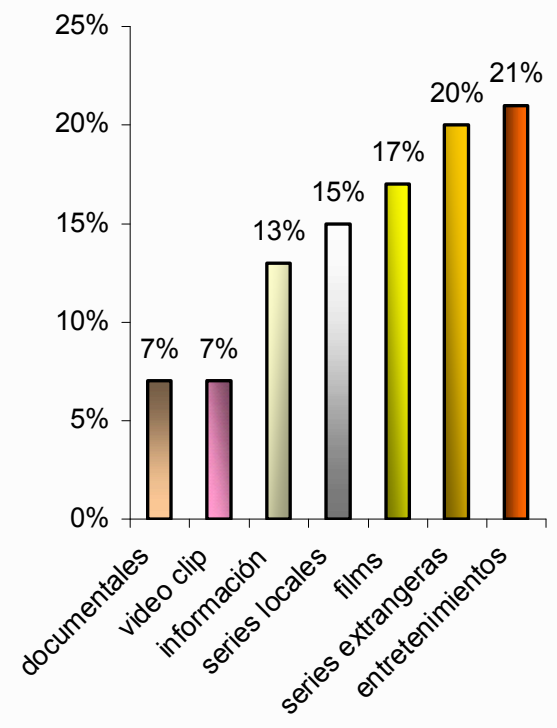

$\square$ documentales

$\square$ video clip

$\square$ información

$\square$ series locales

$\square$ films

$\square$ series extrangeras

$\square$ entretenimientos 


\section{Cine}

El 68 por ciento asiste a salas comerciales más de dos veces al mes (gráfico 28). Un tercio del total to hace una vez en la semana. Un porcentaje significativo, no va nunca al cine (teniendo en cuenta que el sector estudiado es el de estudiantes de imagen) (5 por ciento). El lugar elegido para ver cine es en casa, registrándose un aumento progresivo desde la televisión de aire (58 por ciento), la televisión de abonado (83 por ciento) y en cinta videocasete (92 por ciento). En esta modalidad casi el 70 por ciento ve 1 película o más por semana. Los géneros de preferencia son el drama y el suspenso. (Gráficos 2930).

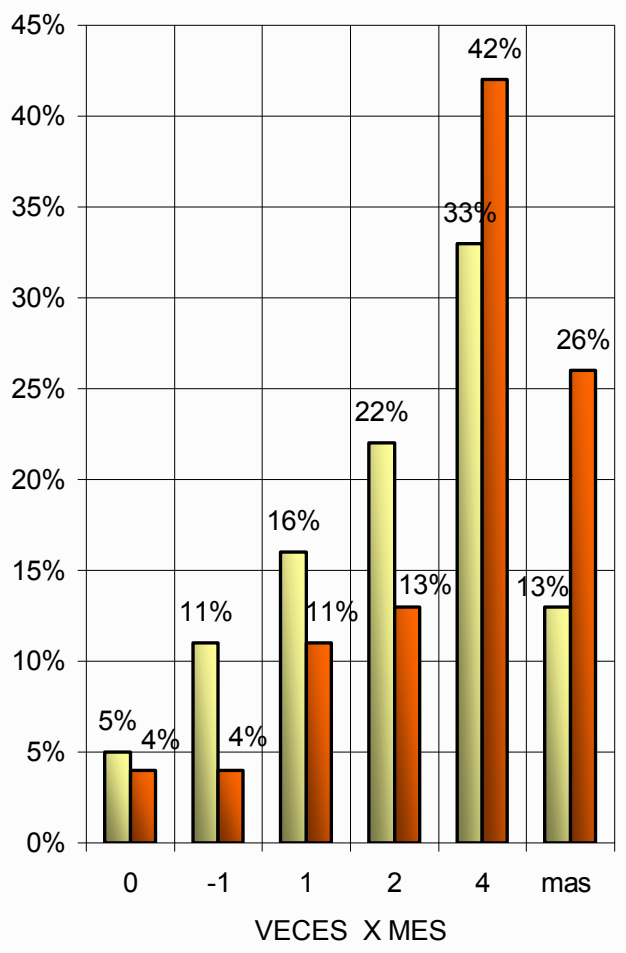




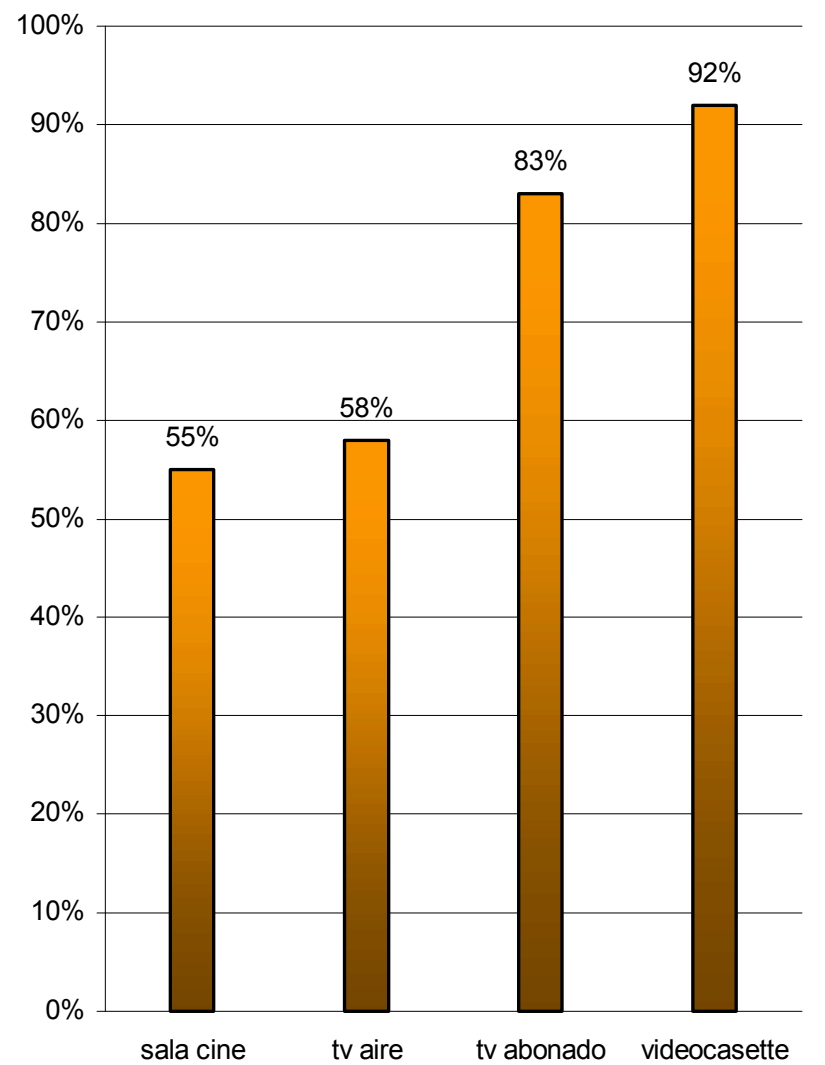




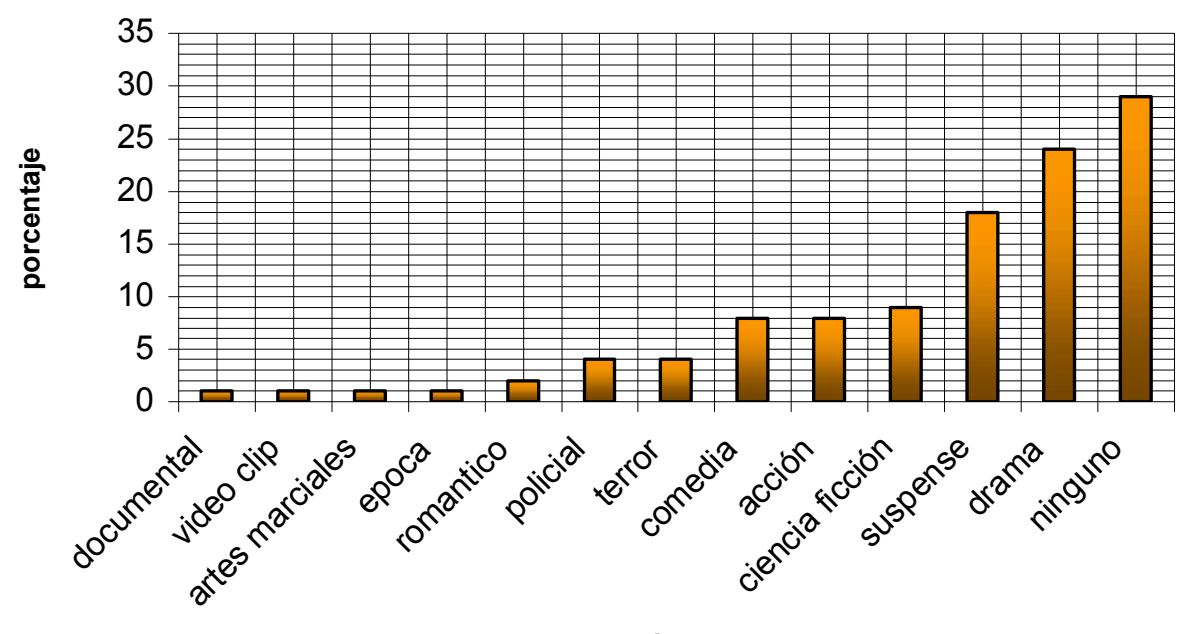

género

(*) muestra de 153 alumnos de comunicación audiovisual 


\section{Informática}

Casi un 70 por ciento posee computadora, de los cuales un 26 por ciento del total hace uso de Internet. El concepto de uso es mayoritariamente para el trabajo (solo un 5 por ciento señala solo para esparcimiento). El ocio involucra mayoritariamente el uso del juego electrónico, desestimando las posibilidades de la red) (gráfico 31). Un 37,5 por ciento del total usan procesadores de imagen y/o sonido. 

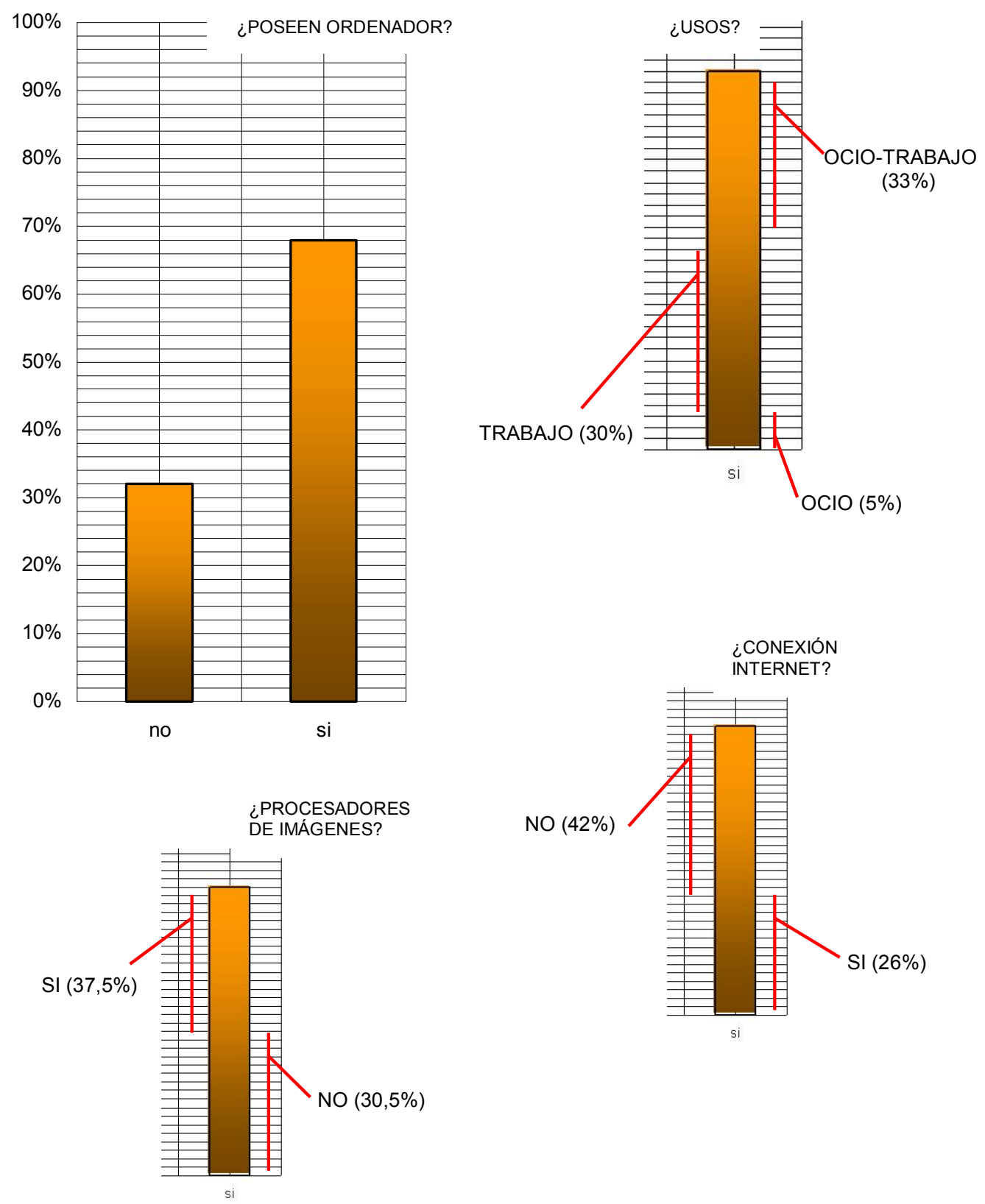


\section{Radio}

Las características en el consumo radiofónico muestran una preponderancia de la escucha de música por sobre el programa de interés general o informativo en la radio de Frecuencia Modulada (FM) y de la información por sobre la música en la Amplitud Modulada (AM). Sin embargo la franja que escucha con un interés informativo- musical es muy amplia (tanto en AM como en FM). (gráfico 32). Las curvas del gráfico 33 muestran que para la $A M$ se produce un pico en cantidad de oyentes en 2 horas por día. Esto se corresponde con un interés puntual de un programa en particular (A. Dolina o fútbol). En cambio en FM se invierte la tendencia, existen dos picos: uno correspondiente a bajo consumo (menos de una hora día) y otro para más de 6 horas por día (aquellos que la tienen todo el día prendida). Es de destacar que nadie se declaró no oyente radiofónico. El gráfico 34 muestra la tendencia mayoritaria por la FM. El 51 por ciento que escucha ambas se corresponde con lo ya señalado como un interés por algún programa en particular. 


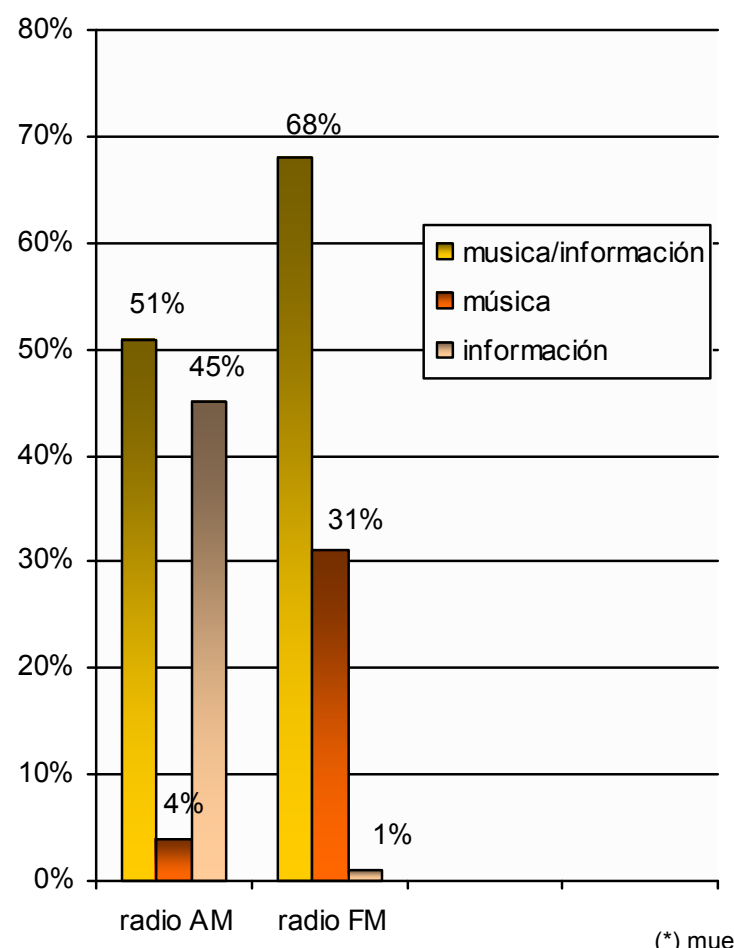

Gráfico 33 - Tendencias Consumo diario de Radio AM-FM (*)

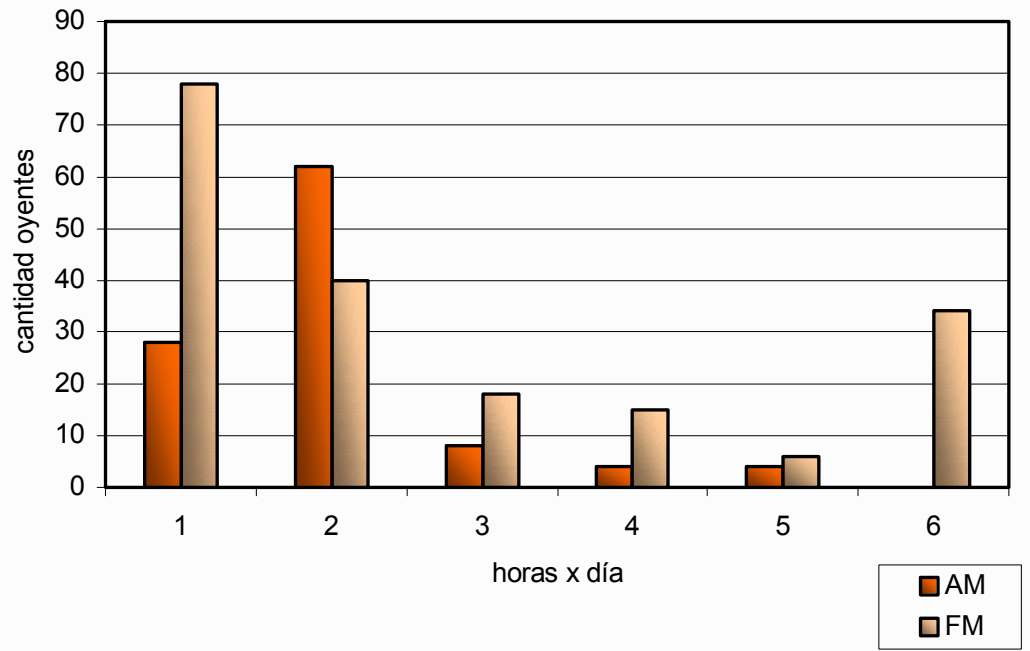







$-6-$

EVALUACIÓN DEL MODELO

LECTOR-ESCRITOR AUDIOVISUAL 


\subsection{El Lector Audiovisual}

Continuando con nuestro análisis, fue necesario a partir de los datos procesados en las encuestas, ensayar una tipología general de lector audiovisual de manera que el objeto de nuestro estudio pudiera ser reconocido dentro del modelo lector-escritor audiovisual que nos propusimos ensayar. De la observación y contraste de los datos obtenidos en la aplicación del modelo interpretativo podemos decir que los relatos de ficción preferidos se corresponden con seriales (nacionales e internacionales), que incursionan más en un tratamiento lineal en lo temporal y clásico en lo espacial que en desestructuras y fragmentaciones. En general el análisis de los datos señala una preferencia por esquemas clásicos de imagen y estructura. De todos modos no debemos olvidar que estos números pueden estar afectados por una preponderancia de un tipo de oferta en lo audiovisual mediático: la mayoría de los relatos para consumo juvenil sigue siendo (y hoy más que nunca) telecomedias de enredos tipo norteamericana, formatos que en su origen (Dick Van Dike, Lucille Ball, etc.) asumían determinada forma, siempre supeditada a la producción televisiva: el directo con varias cámaras de estudio, la escena se desarrolla y los cortes se realizan en la consola del directo televisivo. Resultado: cuasi-estricta continuidad espacio temporal. Hoy las comedias televisivas adoptan esta forma, ya no hay necesidad técnico-productiva, sino estética, de respetar el formato para pertenecer al mismo.

Todo esto se complementa con el poco consumo de videoclips. El videoclip, forma expresiva de consumo exclusivo juvenil de avasallante presencia durante los años 1980-1990, parece haber mermado su influencia. Así es que la forma de consumo musical es mayoritariamente a través del medio radiofónico y en frecuencia modulada (radio FM).

Lo anteriormente expuesto se pude sintetizar según el esquema del gráfico 35 : una pirámide invertida que grafica la preferencia a seriales que recurren a esquemas clásicos de representación. 
Gráfico 35 - Esquema Características del lector de imágenes

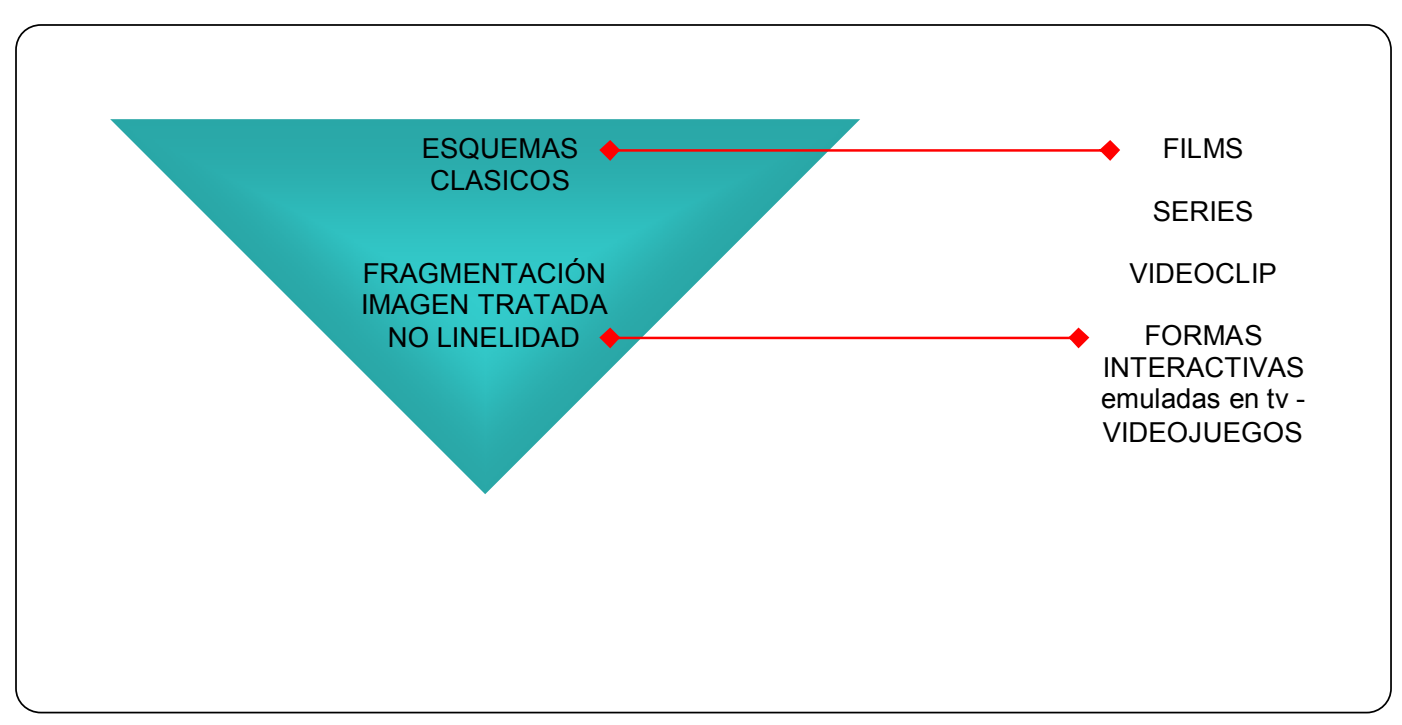




\subsection{El Escritor Audiovisual}

En lo que es la producción audiovisual propia de los alumnos: observamos que los esquemas narrativos responden en su mayoría a modelos lineales. No iterativos, ni serializados. También como ya lo hemos señalado en apartados anteriores gran parte de los alumnos no produce otra forma de representación que aquella que le da la lente de la cámara. Se piensa en el encuadre, en la disposición de los objetos y personas dentro del encuadre, se piensa en iluminar expresivamente (colorear por zonas por ejemplo), en definitiva, se piensa en expresar a través de la representación con métodos pertenecientes al campo expresivo de la cinematografía.

Se detectaron, por supuesto, resoluciones expresivas con esquemas no lineales y formas de representación que hacen uso de las nuevas herramientas. Es importante dentro de este grupo de trabajos aquellos que se gestaron a partir de algún descubrimiento en la posproducción, por ejemplo encontrar que un ruido registrado puede ser modulado y repetido a lo largo del trabajo con importantes resultados expresivos. También se dio el caso de que por dificultades de soporte un material tuviera que soportar sucesivas copias analógicas con la consiguiente degradación de la imagen, degradación visual (saturación y pérdida de color) que finalmente fue utilizada expresivamente.

Lo anteriormente señalado se puede pensar según el siguiente esquema del gráfico 36 . 


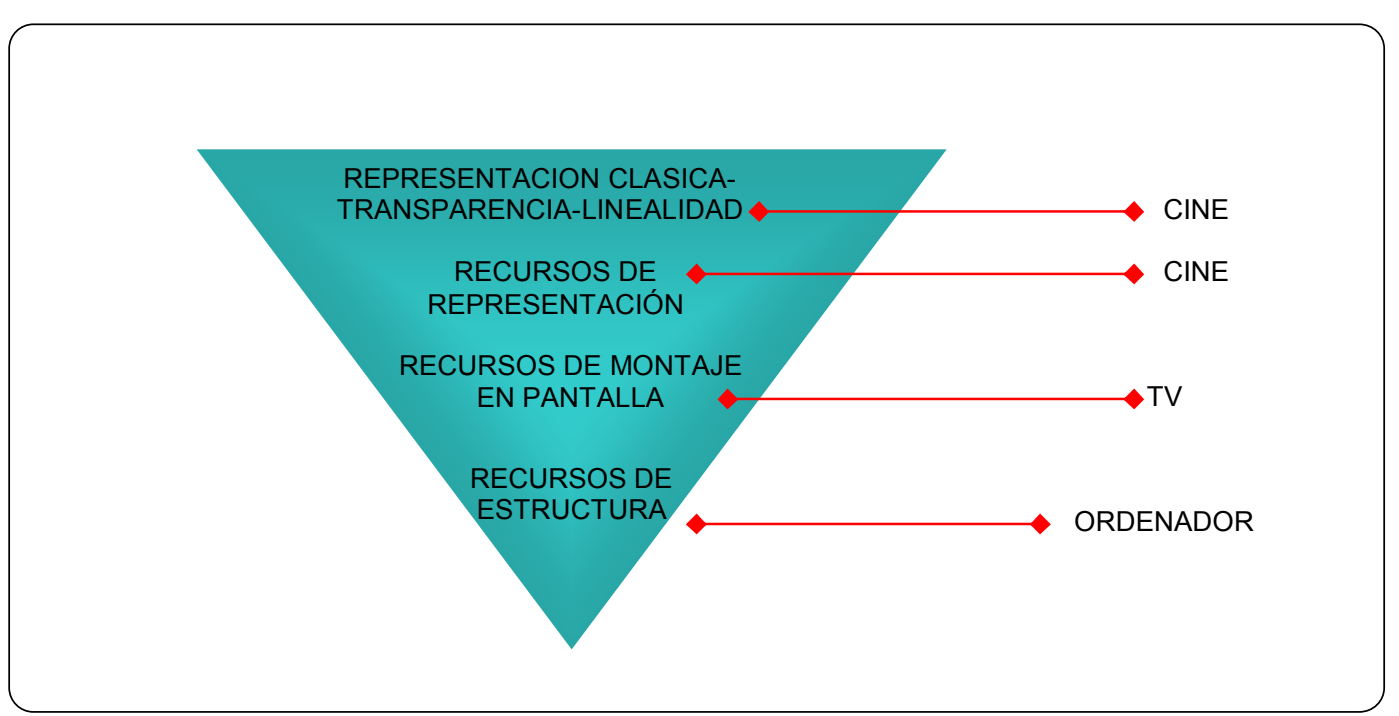

Asimismo podemos también ver que cada una de nuestras clasificaciones en los recursos aplicados (representación, montaje y estructura) puede ser relacionada en cada caso con algunos de los soportes asociados al cine, a la televisión o a las tecnologías informáticas.

La labor docente respondió a una metodología que, según lo planteado, se ocupó centralmente del acto expresivo. La herramienta desarrollada fue la propuesta estética. Este plan estético, este anexo guionístico estético del alumno obligaba a pensar la forma antes de la grabación. El cuaderno de bitácora o memoria del proceso íntegro y la evaluación misma fueron las herramientas para el "día después".

Durante el seguimiento de los alumnos en el proceso en su totalidad (desde concepción de la idea hasta proyección y coloquio con la mesa evaluadora) se observaron dificultades en aprehender el concepto de propuesta estética.

Se observó que es una idea generalizada en los alumnos suponer que la narración es solo en el nivel de lo argumental. De esta manera son serias las falencias al momento de plantearse la conexión entre argumento y estilo. Nuestro trabajo fue entonces producir definiciones y decisiones del grupo en 
toda posible articulación y dialéctica de lo argumental con la puesta de la forma estilística.

De las charlas en el seguimiento de cada grupo (previo a la grabación-rodaje) surgió que la mayoría de los alumnos entiende que la creatividad es solo crear puesta en escena dándole importancia primordial a lo "dramático". Así quien fue dueño de la idea es quien escribió el guión y será presencia infaltable en la posproducción. Según esta idea el guión debe ser "protegido" de los embates del rodaje (con sus dificultades en la maquinaria de producción) y "respetado" al máximo en la posproducción.

La posproducción según estos términos no es momento creativo. El montaje es más una instancia de dar solución a problemas del material obtenido en el rodaje o grabación: dificultades de continuidad en lo lumínico o en lo sonoro, aplicar emparejamientos gráficos, etc. Se piensa el montaje como una gramática de las imágenes que sólo debe ser aplicada en la instancia de escritura del guión técnico-realizativo. El guión y el rodaje son los momentos puramente creativos. Por eso el momento de la posproducción fue más de una vez una instancia no compartida por el grupo realizativo, bastaba con un buen técnico operador de edición (en gral. ajeno al grupo y a la experiencia que venia realizando el mismo) sentado frente a alguien del grupo (generalmente el gestor y dueño de la idea y director que "tradujo" el montaje planteado en el guión técnico).

Sin embargo y a pesar de estas concepciones, el momento de la posproducción (de la edición) propuso y dejó su marca en cada trabajo. Más allá de ingenuidades o actos conscientes la herramienta puesta en juego se integró al trabajo como material con fuerte presencia en la estructura física resistente, creando y sugiriendo resoluciones.

\subsection{Correspondencias entre el Escritor y el Lector Audiovisual}


Según se observó en los perfiles generales, tanto del lector como del escritor de imágenes, existiría una correspondencia directa entre los hábitos de lectura y escritura audiovisuales. Podemos obtener algunas interesantes relaciones al superponer los perfiles característicos del lector y de escritor de imágenes. Observemos el gráfico 37.

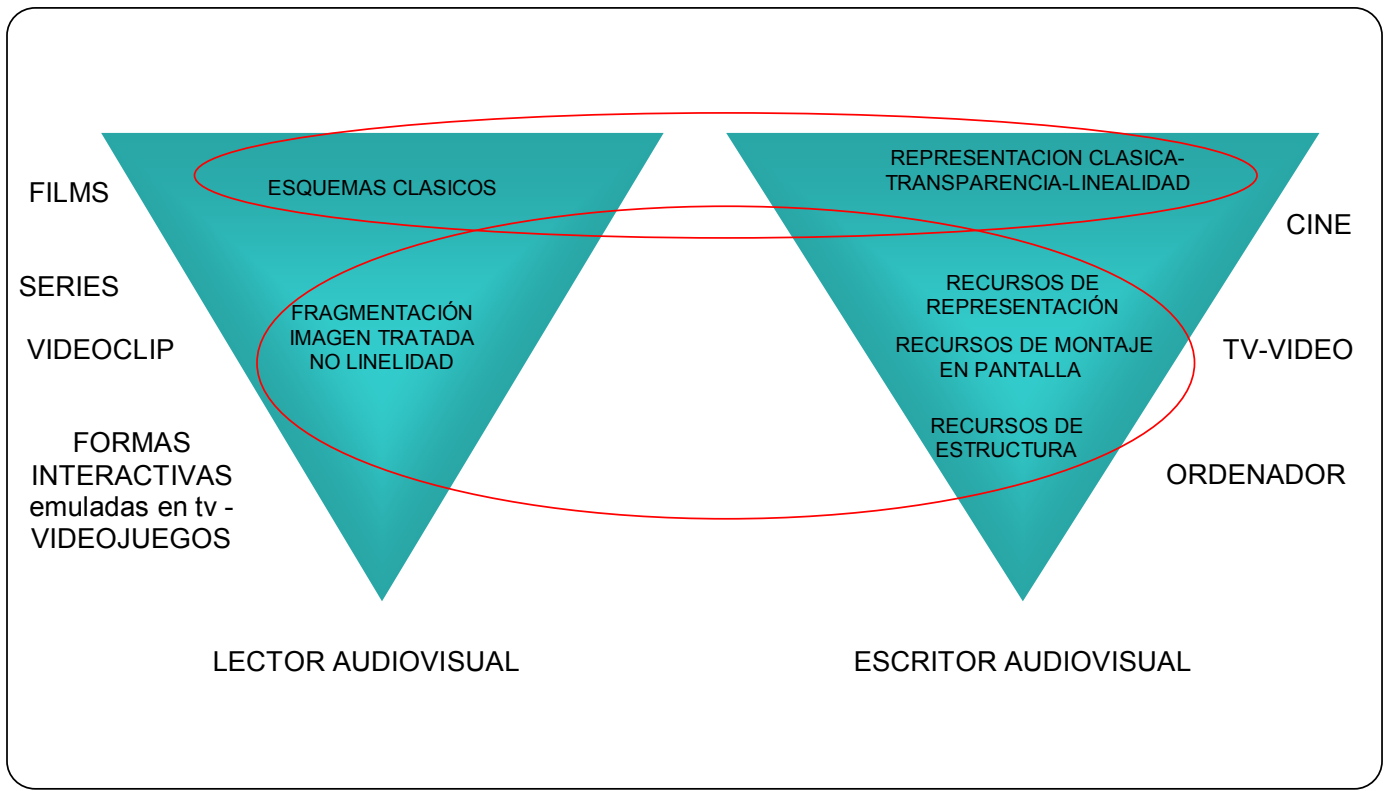

Como decíamos, la base más amplia se correspondería con formas más clásicas y el vértice inferior con aquellas que incluirían recursos de estructura, pictorización, electrificación de la imagen.

Es importante señalar cómo en las graficas la gradación representación-montaje en pantalla-estructura está íntimamente relacionada con la escala cine-tvordenador.

Veamos como este último ordenamiento responde estrictamente a la mayor a menor tradición como medios audiovisuales y por lo tanto a su influencia como productores de formas de representar y ver el mundo. 
El cine ha hecho claro uso de lo que llamamos recursos de representación, asimismo son raros los recursos de montaje en pantalla y nunca estuvo dentro de sus posibilidades tecnoexpresivas la interactividad, mas allá de la posibilidad de emularla, como ya lo hemos señalado en el ejemplo de Corre Lola, Corre (Tykwer, 1998).

La televisión y el video son los que han llevado a un uso habitual (y definitivamente emparentado con su esencia) los recursos de montaje en pantalla y la electrificación de la imagen. Como así también la fragmentación espacial y temporal. Además la interactividad esta entre sus posibilidades técnicas de la televisión.

Y por ultimo el ordenador es el que incorpora la posibilidad de interactividad.

Ordenarlos de este modo, CINE-TV-ORDENADOR, no solo implica jerarquizarlos en su antigüedad, sino también y esto es lo que se relaciona con la escala representación-pantalla-estructura, reconocer que su antigüedad como medio es también su capacidad e importancia para condicionar sobre los imaginarios de nuestro lectores-escritores audiovisuales. 
- 7 -

CONCLUSIONES

$Y$

PROPUESTAS 


\subsection{Conclusiones}

Decíamos en el planteo de la hipótesis fundamental de la investigación que:

La existencia de nuevas herramientas involucradas en el proceso de escritura audiovisual determinan nuevas operatorias que influyen en forma directa en la escritura misma, y por ende en su producto, esto es en los textos audiovisuales. Asimismo los hábitos de consumo audiovisual, entendidos como lectura audiovisual influirían en la determinación de un imaginario previo. Las preferencias en la lectura audiovisual estarían también condicionando las elecciones de forma a la hora de escribir audiovisualmente.

Podemos entonces concluir, a partir de los procesos observados en los capítulos 5 y 6 en donde se aplica el esquema lector-escritor audiovisual y de los modelos pedagógico y teórico expuestos en los capítulos 3 y 4 , que la incidencia de las nuevas tecnologías en la producción audiovisual se produce básicamente en dos niveles, en dos esferas claramente delimitadas.

- Por un lado estas transformaciones se expresan en la conformación de nuevos imaginarios a través de la modificación de los hábitos de lectura audiovisual, estos hábitos de lectura van definiendo un perfil del futuro productor de imágenes que luego necesariamente plasmará estos gustos, estas visiones. Este imaginario es definido fundamentalmente por una forma de mirar, y por ende por un deseo de representar, de reconstruir el mundo a través de una imagen. Esta dinámica se puede esquematizar según recoge el gráfico 38. 


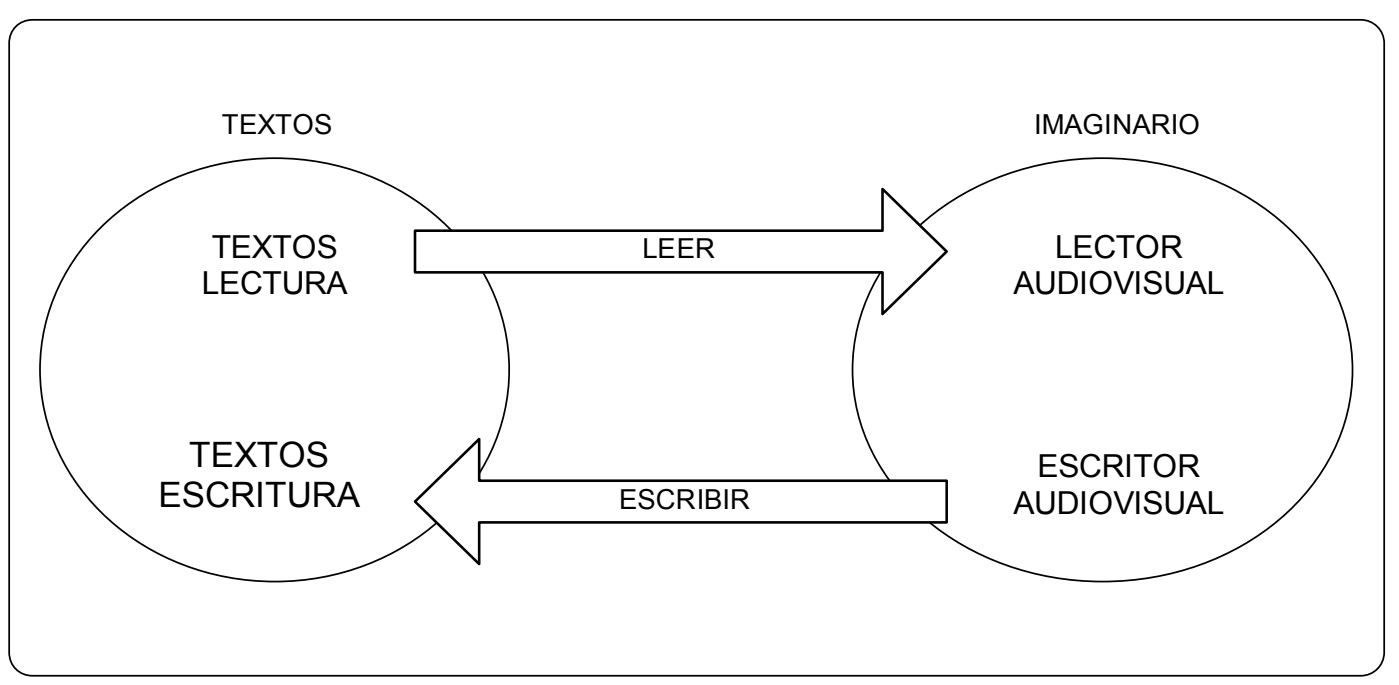

- El otro aspecto importante de nuestra hipótesis que ha sido claramente verificado en nuestro proceso indagatorio, es aquel que señala que en el mismo proceso de escritura audiovisual las herramientas involucradas en la producción afectan al texto mismo. Concluimos que debido a la existencia de herramientas nuevas, los procesos durante la escritura del texto se ven modificados. De este modo el acto mismo de escribir es el afectado. Revisemos entonces el gráfico anterior incorporando al mismo los procesos mencionados. El gráfico 39 recoge dichas relaciones. 
Gráfico 39 -relaciones escritura y lectura / conformación imaginario/ herramientas

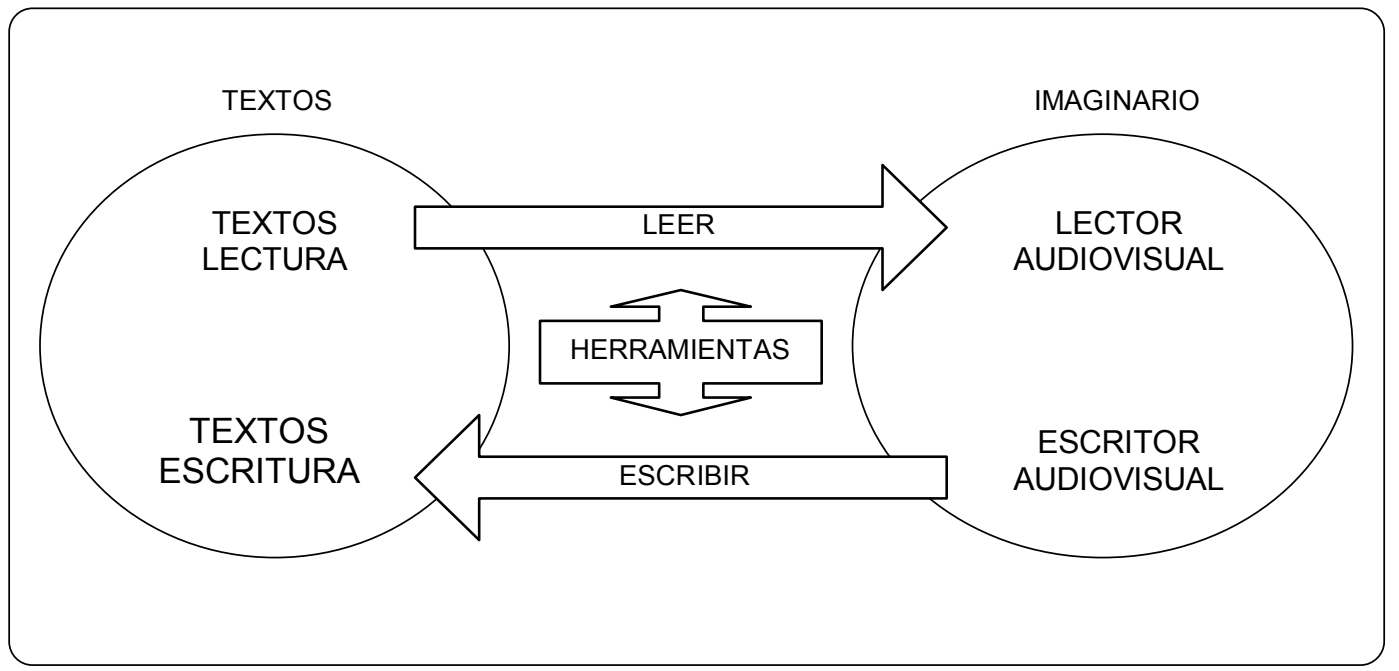

- La dinámica que se establece según lo señalado es compleja: las herramientas producen una doble afectación, lectura y escritura de los textos audiovisuales son modificados. Los nuevos procedimientos escriturales generan nuevos productos audiovisuales, las nuevas formas de lectura influyen en la conformación de nuevos imaginarios y por lo tanto de nuevas formas de ver y representar.

- En correspondencia con lo expuesto en el apartado anterior, esta dinámica señala una relación directa entre tipos de lectura y tipos de escritura (según se detalla en el grafico 37 del capitulo 6). Es así que la influencia de las nuevas tecnologías en las producciones audiovisuales observadas tiene su correlato con los hábitos de lectura audiovisual. Se produce entonces un ordenamiento según la mayor o menor tradición de los medios audiovisuales y por lo tanto de su influencia como productores de formas de representar.

\subsection{Algunas reflexiones finales a modo de propuestas para un nuevo análisis}


La posibilidad de llevar adelante una serie de propuestas surge fundamentalmente desde la experiencia concreta pedagógica observada. Los escritos audiovisuales y sus correspondientes autores (escritores) fueron observados (como se ha explicado en el capitulo 2 donde se explica la metodología seguida) mientras formaban parte de un proceso concreto de enseñanza audiovisual. De manera que para nosotros adquiere fundamental importancia toda evaluación que podamos hacer de lo que hemos denominado el "escenario pedagógico institucional".

Decíamos, en nuestro análisis de las condiciones del funcionamiento docente en el departamento de comunicación audiovisual de la U.N.L.P., que el papel de las nuevas tecnologías era un tema central de debate, esto se expresaba mayoritariamente en la inquietud por la escasez de recursos tecnológicos. Mas allá de la necesidad real de renovación de equipamiento, lo real es que poco preocupaban (tanto a los docentes como a los alumnos) las posibilidades de problematizar el complejo proceso de escritura con imágenes, proceso en el que necesariamente están involucradas las tecnologías en su papel de herramientas para la preparación, y realización de un discurso audiovisual. Ahí pensamos es donde nuestra labor docente tiene su razón, apostar a que una asignatura del área realizativa - productiva no se desentienda de contener y fomentar producciones audiovisuales vinculadas con las nuevas tecnologías desarrollando metodologías acordes.

El modelo escritor-lector de imágenes devela, según lo explicado en nuestra evaluación de modelo aplicado del capitulo 6, relaciones directas. Los modelos más instalados de lectura son aquellos que responden a los de más historia y tradición, la cinematografía y el serial televisivo se instalan como formas preponderantes de consumo e inducen formas resolutivas en el proceso de escritura audiovisual. El contacto y uso con las tecnologías necesariamente influyó, a veces traumáticamente, otras en felices encuentros con la expresión y creatividad.

Por otro lado el "fetichismo" (Vallina, 1995) y la "fobia" tecnológicos pueden ser vistos como síndromes que expresan dos caras de la misma moneda, ambos 
aspectos se presentan claramente como formas radicalmente opuestas de entender el problema de la apropiación de las nuevas herramientas. Fetichismo y fobia inducen formas de entender la tecnología erróneamente: por un lado, se piensa que se resuelve todo si se tiene acceso (a las nuevas herramientas), por el otro nos encontramos con la parálisis que produce el miedo. Un temor que paraliza para la apropiación, y que incluso se magnifica en la mitificación del peligro de "ser poseído".

Fetichismo y fobia sintetizan pensamientos que en cierta forma deshumanizan las tecnologías. Humanizar la tecnología es darle la dimensión humana que otorga la verdadera apropiación. El problema de cómo apropiarnos de las tecnologías se ha expresado históricamente en esos debates sobre las consecuencias de cada nuevo desarrollo tecnológico humano. Vemos que hemos realizado un gran bucle, (un matemático for next para estar a tono con el tema que tratamos), retomando estratégicamente el inicio de este escrito: el síndrome Frankenstein, el temor frente a la propia invención, frente al hecho consumado de haber creado (de acercarse a la posibilidad de ser dios) es también sentirse un nuevo prometeo, inventar nuevas realidades es robarle el fuego a los dioses. El tema: el temor, el terror a la criatura es actualizado, se nos acerca encarnando en $H A L$ o en Matrix.

Las resistencias, los temores, y la mitificación (ni la imprenta de Gutenberg, cinco siglos antes de la televisión, escapó a esta tendencia y fue discutida como generadora de lectura individual aislante), decimos que son consecuencias de miradas erróneas del fenómeno. Frente a esta manera de entender el problema, nuestras conclusiones nos señalan la experiencia como central. Experiencia y vivencia frente a la tecnología como forma de apropiación. $Y$ si tenemos que hablar de experiencias y vivencias siento la tentación de volver a escribir nuevamente en primera persona y describir las mías con algunas de las nuevas tecnologías:

“... la primera vez que usé mi flamante cuenta de correo electrónico lo hice en un cibercafé, el reloj cronometraba la tarifa y yo intentaba escribir casi una novela epistolar... poco tiempo bastó (sobre todo por mi bolsillo) para darme 
cuenta que la cosa no era escribir como lo hacia cada vez que me carteaba con la tía Molly. ¡Santiaguito escribíme unas líneas! Entonces era sacar ganas de no sé donde y sentarse frente a por lo menos cuatro hojas en blanco con la intención de completarlas. Solito (y también observando la escritura electrónica de los más experimentados) terminé definiendo íntimamente al mail como un tipo raro de correo en mixtura con teléfono, televisión y máquina de escribir. Teléfono porque siempre fui un convencido usuario telefónico de tipo $A$ (informacional, casi unidireccional): lo mío siempre fue muy concreto (Hola, que tal, nos vemos en tal lado, chau). Así de simple, para los usuarios de tipo A el teléfono sirve para acordar en que lugar y a que hora encontrarse para charlar. También pertenezco al subtipo 2. Para esta tipología de usuarios (A.2) es esencial el contestador automático, en general no quieren ser "encontrados" sino "ir al encuentro" es por eso que no ven con agrado el usar móvil y sienten profunda satisfacción en llegar a casa y escuchar el buzón de mensajes del teléfono de línea mientras beben una cerveza helada. Completan mi propia invención, mi propia criatura Frankenstein la televisión y máquina de escribir: rayos catódicos y teclado se lo hacían recordar a mi cuerpo, mis ojos se paseaban nuevamente cansados por una pantalla, mis manos tenían que abandonar el mouse... Poco académico lo expuesto... pero asombrosamente efectivo en mi vida personal, pude a partir de mi experiencia reconocer el nuevo medio. ¡Escribir mails no era un sufrimiento epistolar como me lo había imaginado! Definitivamente sé que por ahora no usaré el messenger porque cuando estoy trabajando (como en este mismo instante en que estoy escribiendo esto en un ordenador conectado) lo que menos desearía es que alguien caiga del cielo (de los bits) en mi escritorio diciéndome ¡hola!"

La lista de experiencias podría ser numerosa, interminable, tanto cuanto más profundo sea nuestro contacto con las nuevas tecnologías. Cada uno de nosotros tendría en su especificidad profesional o en su cotidianeidad un blanco y un negro que aportar a favor o en detrimento. La parcialidad en la observación e interpretación de estos síntomas sea tal vez la razón por la cual las opiniones sean encontradas.

Seria una ingenuidad de nuestra parte pensar que en este mundo global la interculturalidad está garantizada por la existencia de las nuevas tecnologías. Así el término globalización, la mayoría de las veces, más se ajusta 
semánticamente a generalización de males, que a bondades o gratificaciones por el desarrollo tecnológico de la modernidad. El mundo sigue siendo un lugar que deja bastante que desear, fundamentalmente en lo que respecta a la distribución y acceso a los bienes (no solo materiales). Pero también es necesario abordar las dificultades desde otro ángulo, aceptando la escasez y dificultad de acceso a las nuevas herramientas como un problema, y completando el circulo relacionante de las herramientas y su usuario.

Y es así que este escrito, memoria de un proceso investigativo, es también la memoria de un proceso pedagógico audiovisual que intenta dar respuesta a estas realidades con la premisa de que es posible comprender y mejorar las consecuencias de uso y accionar de las técnicas, las tecnologías, y las herramientas si pensamos en como mejor utilizarlas, sabiendo que en ese uso nos las apropiamos realmente (Guedeón, 2002).

Las huellas de las condiciones en que ha sido producido el texto (Verón, 1997) es lo que buscamos delimitar por la aplicación del modelo "Lectura-escritura". Estas huellas impresas en el texto audiovisual son las que surgen por la modificación de la práctica "escritura audiovisual" y por los nuevos imaginarios en los escritores mismos, imaginarios que se moldean en la dinámica de los nuevos hábitos de lectura audiovisual (y también en el mismo ejercicio de la escritura audiovisual).

Es inevitable que las ficciones sean catalizadoras de experiencias cotidianas sobre la forma de percibir y representar el espacio y el tiempo poniendo en juego también revisiones sobre las relaciones sociales y culturales. (Stam 2001).

Las relaciones y transformaciones son mutuas, el lenguaje es un poderoso estructurador del mundo, pero el mundo, la realidad, también estructura y da forma al lenguaje. Esta dinámica, este movimiento no-unidireccional se expresa claramente en nuestro modelo, los textos son expresión acabada de un lenguaje audiovisual, lectura y escritura audiovisual establecen, se entrelazan e 
interrelacionan en la conformación de un imaginario (según el esquema del gráfico 39).

Las condiciones en las que ha sido producido el texto audiovisual son aquellas que surgen en la dinámica del imaginario del lector-escritor. Las prácticas que están en juego en esta dinámica son las acciones de lectura y escritura. Ambas prácticas están "signadas" por las nuevas tecnologías. La escritura por la existencia de nuevas herramientas en los procesos mismos de factura del texto audiovisual y la lectura por la existencia y disponibilidad de nuevas formas discursivas audiovisuales ejemplificadoras y/o estimuladoras de nuestro lectorescritor.

A esta altura vale la pena recordar la teoría de la formatividad de L. Pareyson. La conceptualización de "la forma" como "organismo" plantea una superación de la definición de la misma a partir de los polos forma-contenido o forma-materia.

Revalorizando los procedimientos formativos de la obra, y privilegiando el proceso o modo de formar-representar (poética) por encima del objeto concreto y acabado. Según Pareyson cada obra (artística) constituye una remisión a sí misma, a su propio universo formativo, el diálogo con la materia que constituye la obra es esencial al acto expresivo.

"...el concepto de materia (como) todas aquellas diversas realidades que chocan y se interfieren en el mundo de la producción artística: el conjunto de "los medios expresivos", las técnicas transmisibles, las preceptivas codificadas, los diversos "lenguajes" tradicionales, los instrumentos mismos del arte... (el) diálogo con la materia, indispensable en toda producción artística: en el que la presencia de la estructura física como resistencia permite avances, obstáculos, sugerencias de acción formativa." (Eco U., 1990)

Con estas ideas se ha perfilado nuestra indagación, sabiendo que en todo producto audiovisual intervienen en la conformación de su estructura física los distintos soportes (video analógico, video digital, fílmico en sus distintos pasos), 
y los formatos (ficción, documental, lo televisivo, lo perteneciente a Internet, etc.).

Sabiendo también que los medios expresivos surgen de las elecciones de encuadre, de montaje (definiendo la espacialidad y la temporalidad), de la iluminación elegida, de la dirección y elección de actores, etc.

Que las técnicas transmisibles son cada uno de los aspectos técnicoartesanales puestos en juego en los distintos momentos de la construcción del texto, cualquiera fuera su forma de producción y organización del trabajo.

Que las preceptivas codificadas pueden encontrarse en las gramáticas de montaje, en los preceptos industriales de lo que sería una iluminación correcta, o un guión correcto, etc. $Y$ que los lenguajes tradicionales pueden provenir de las otras disciplinas (teatro, literatura, danza, la pintura, la escultura, la arquitectura, etc.) o del interior de lo audiovisual mismo (lo clásico cinematográfico).

Todo esto está en pugna en el acto expresivo, en su formación, en su origen. Todo esto también es constantemente alimentado en el proceso pedagógico. La apuesta es que la "acción" y la "reflexión" puedan integrarse en un proceso productivo audiovisual que sea una experiencia en donde la tecnología y las técnicas no se entiendan como un saber parcelado, solo de especialistas, sino como un material más con el que experimentar a la hora de expresar. Técnicas y tecnologías que se encaucen en realidades (sociales) concretas, que su mismo uso defina y amplíe sus potencialidades.

La lucha del pequeño David contra el Goliat de la dominación y violencia simbólica tiene como posible escenario nuestras aulas, y la única honda disponible para acertar la piedra fulminante entre los ojos del fabuloso gigante es hacer que los que escriben y los que leen imágenes tengan elementos para seguir apropiándose de los símbolos. 


\section{BIBLIOGRAFÍA Y MATERIALES}




\section{CITAS BIBLIOGRÁFICAS}

Galeano Eduardo en Tejidos. Antología. Octaedro. Barcelona. 2001. (P. 161)

Shelley Mary en Frankenstein o el moderno prometeo. Traducido de la versión en catalán. Ed. de la Magrana. Barcelona. 1983. (P. 49)

Ibáñez Jesús, Nuevos avances en la investigación social, Ed. Proyecto A, 1998, Barcelona. P. 83

Samaja Juan en Epistemología y Metodología. Elementos para una teoría de investigación científica. Eudeba. Buenos Aires. 1995. (P. 13)

Escrito Comisión Pro-reapertura de la carrera de cinematografía de la Universidad Nacional de La Plata. 1984.

Resolución administrativa de la Universidad Nacional de La Plata, año 1984.

Escrito del anteproyecto del plan de estudio para la Licenciatura en Comunicación Audiovisual de la Universidad Nacional de La Plata. 1987.

Propuesta metodológica del plan de estudios de la licenciatura de Comunicación Audiovisual. Facultad de Bellas Artes de la Universidad Nacional de La Plata. 1987. P12.

Verón Eliseo, en Semíosis de lo ideológico y del Poder. La mediatización. Secretaría de extensión Universitaria Facultad de Filosofía y Letras Oficina de publicaciones Ciclo Básico Común, Universidad de Buenos Aires, 1997.

Llorente Bilbao José Ignacio, "Narrativa no lineal e interacción textual" I Congreso Internacional de Comunicación y Realidad. Los impactos de las tecnologías de la información y de la comunicación en las realidades sociales. 
Publicación Tripodos Lenguaje-Pensamiento-Comunicación. Universitat Ramón Llul. Barcelona. 2000. (P. 437)

Ravera Rosa en Estética y crítica. Los signos del arte.

Bettetini G., Colombo F. en Las nuevas tecnologías de la comunicación. Instrumentos Paidós. Barcelona. 1995. (P. 30)

Virilio, Paul en El Arte del video: Introducción a la Historia del Vídeo Experimental. RTVE: Serval. Barcelona.1991. (P. 14)

Bazin André en ¿Qué es el Cine? RIALP. Madrid.1966. (P.123)

Duguet Anne -Marie. En El Arte del video: Introducción a la Historia del Vídeo Experimental. RTVE: Serval. Barcelona.1991. (P. 67)

Agel Henri, Estética del Cine, Ed. Eudeba, Buenos Aires, 1968. (P. 29)

Sánchez-Biosca, El Montaje Cinematográfico, Paidós Comunicación. Barcelona. 1996 (P. 36, 72, 74)

Eisenstein Serge en Teoría y Técnica Cinematográficas. Libros de Cine RIALP. Madrid. 1989. (P. 105, 109, 110).

Bongiovani Pierre en Eisenstein y Digital. La Revolución del Video. Publicación de Centro Cultural Ricardo Rojas Univ. Buenos Aires. 1996. (P. 77)

Machado Arlindo en Técnicas de la fotografía: la síntesis numérica. La Revolución del Video. Publicación de Centro Cultural Ricardo Rojas Univ. Buenos Aires. 1996. (P. 71, 72)

Tyler Parker, Cine Underground. Historia Critica. Ed. Planeta. Barcelona. 1973. (P. 130) 
Chion Michel en La Audiovisión: Introducción a un análisis conjunto de imagen y sonido. Paidos. Barcelona. 1993. (P. 80)

Bresson Robert en Notas sobre el Cinematógrafo. Ed. Ardora. 1997. Madrid. (P.22, 48)

Murray Janet $\mathrm{H}$. en Hamlet en la Holocubierta: El Futuro de la narrativa en el Hiperespacio. Paidós, multimedia, Digital. Barcelona. 1999. (P. 262, 268, 280, 291)

Landow George P. en Hipertexto. La convergencia de la teoría crítica contemporánea y la tecnología. Ed. Paidós multimedia. Barcelona. 1997. (P.103, 110)

Moreno Isidro en Televisión Digital. ¿Interactiva? Comunicación Audiovisual y Nuevas Tecnologías. Vicente Peña Timón (Coord.) Servicio de Comunicaciones de la Universidad de Málaga. 1998. (P. 143)

Citado por Landow George P. en Hipertexto. La convergencia de la teoría crítica contemporánea y la tecnología. Ed. Paidós multimedia. Barcelona. 1997. (P.101)

Miller Henry en Sexus. Biblioteca El Mundo. Madrid. 2002. (P. 17, tomo I)

Aumont Jacques en El ojo interminable. Cine y Pintura. Paidós. Barcelona. 1997. (P.81)

Sangro Colón Pedro, Teoría del Montaje Cinematográfico: textos y textualidad, Publicaciones Univ. de Salamanca, 2000 (P. 296)

Comolli Jean Louis Filmar para ver. Escritos de Teoría y Crítica de Cine. Ed. Simmurg/ Cátedra La Ferla. Buenos Aires. 2002. (P. 66, 81, 91,92) 
Borges Jorge Luis en Poema de los dones. Antología Personal. La biblioteca Argentina. Ed. Sol 90. Barcelona. 2001. (P. 162, 163)

Salt Barry, Film Style and Technology: History and Análisis. Ed. Starword. Londres. 1992. (P. 35-175)

Vallina Carlos en Análisis y Propuestas de Transformación de la Pedagogía Audiovisual Universitaria Periodismo y Comunicación Social-UNLP. Periodismo y Comunicación Social-UNLP. La Plata. 1995. (P. 27)

Tàpies Antoni en La realidad como arte. Por un arte moderno y progresista. Colección de arquitectura. Valencia. 1989 (P. 277, 278)

Guedeon J. C., y Autores Varios La Postelevisión - Multimedia, Internet y Globalización económica. Ed. Icaria, Antrazyt. Barcelona. 2002. (P.59)

Eco Umberto en La definición del Arte - La Estética de la Formatividad y el concepto de Interpretación. 1990. 


\section{BIBLIOGRAFÍA:}

- Agel Henri, Estética del Cine, Ed. Eudeba, Buenos Aires, 1968.

- Alonso Erausquin Manuel Fotoperiodismo Formas y Códigos. Ed. Síntesis. Madrid 1995.

- Alsina Thevenet, H. Y Romaguera I Ramio, J. Textos y Manifiestos del Cine. Ediciones Cátedra, Signo e Imagen.1989.

- Autores Varios. Contaminaciones: del Videoarte al multimedia. Compilación de textos Jorge La Ferla. Secretaría de extensión Universitaria Facultad de Filosofía y Letras Oficina de publicaciones Ciclo Básico Común, Universidad de Buenos Aires, 1997.

- Autores Varios. El Medio es el Diseño. (comp. J. La Ferla y M. Groisman). Eudeba. Buenos Aires. 1998.

- Autores Varios. Lexique L'audiovisuel. Ed. Dalloz. 1990. Paris.

- Autores Varios. Dictionary of image technology. Third Edition BKSTS. London . 1994.

- Autores Varios. Cinema, Art y Pensament. Ed. Universitat i Ajuntament de Girona. Girona. 1999.

- Baudrillard, Jean. Videoesfera y sujeto fractal. Cátedra. Madrid, 1985.

- Bayer, Raymond. Historia de la Estética, Fondo de Cultura Económica, México, 1965 (ed. orig. en francés, 1961).

- Bazin, André. ¿Qué es el Cine? RIALP. Madrid.1966.

- Beatriz Sarlo Estética y Pospolítica. Un recorrido de Fujimori a la Guerra del Golfo. Cultura y Pospolítica. El debate sobre la modernidad en América Latina. Compilación Néstor García Canclini. Publicación del Cons. Nac. Para la cultura y las artes. Méjico. 1991.

- Benjamin, Walter. La obra de arte en la época de su reproductibilidad técnica, en: Discursos interrumpidos I, Taurus, 1990.

- Bettetini G., Colombo F. Las nuevas tecnologías de la comunicación. Instrumentos Paidós. Barcelona. 1995.

- Bonet, E. - Dols, J. - Mercader, A. Y Muntadas, A. En torno al Video. Editorial Gustavo Gili. Barcelona, 1980.

- Borges, Jorge Luis El Jardín de senderos que se bifurcan. Prosa Completa. Ed. Bruguera. Barcelona. 1980. 
- Bresson Robert Notas sobre el Cinematógrafo. Ed. Ardora. Madrid. 1997.

- Bürch, Nöel. El Tragaluz del Infinito. Ed. Cátedra. Madrid, 1991.

- Calabrese, Omar. La era Neobarroca, Cátedra, Madrid, 1994.

- Cardozo, Cláudio. Corpo e Ciberespacio. Universidade Federal de Bahía, Brasil.1996.

- Casetti, Francesco, La cultura, el arte y el pensamiento. Teorías del cine, Cátedra, Madrid, 1994.

- Cassirer, Ernst. Antropología filosófica, Fondo de Cultura Económica, México, 1992 (ed. orig. en alemán, 1944).

- Català Doménech Josep. La Puesta en Imágenes. Conceptos de dirección cinematográfica. Paidós Comunicación. Madrid. 2001.

- Català Doménech Josep. La Violación de la mirada. La Imagen entre el Ojo y el Espejo. Fundesco. Madrid. 1993.

- Cebrian Herreros M. Fundamentos de Teoría y Técnica de la Información Audiovisual. Ed. Alahambra. Madrid 1988.

- Chion Michel La Audiovisión. Paidós. Barcelona. 1993.

- Comolli Jean Louis Medios Audiovisuales. Ontología, Historia, y Praxis Autores Varios. Comp. Jorge La Ferla. Textos sobre documental Taller de escritura Paris VII. Técnica e ideología. EUDEBA. 1999.

- Comolli Jean Louis Filmar para ver. Escritos de Teoría y Crítica de Cine. Ed. Simmurg/ Cátedra La Ferla. Buenos Aires. 2002.

- De Las Heras A. Navegar por la información Fundesco. Madrid. 1991.

- Dawn Ades. Photomontage. Ed. Thames and Hudson. London. 1993.

- Duguet Anne Marie. Video, La Memoire au Poing. Ed. Hachette, Paris. 1981.

- Eco, Umberto. Obra abierta, Ariel, Barcelona, 1990

- Eisenstein Serge. Teoría y Técnica Cinematográficas. Libros de Cine RIALP. Madrid. 1989.

- Eisenstein, Serge. El Sentido del Cine. Siglo Veintiuno Editores. Buenos Aires, 1974

- Eliseo, Verón. Semíosis de lo ideológico y del Poder. La 
mediatización. Secretaría de extensión Universitaria Facultad de Filosofía y Letras Oficina de publicaciones Ciclo Básico Común, Universidad de Buenos Aires, 1997.

- Fargier J. P., Video escrituras. Publicación del Centro Cultural Ricardo Rojas. Cuarto Festival Franco Latinoamericano de Vídeo Arte. Buenos Aires .1995.

- Ferrer, Christian. Mal de ojo. Ed.Colihue. Buenos Aires, 1977.

- Getino, Octavio. Cine Latinoamericano, Economía y Nuevas Tecnologías. Serie Comunicación y Cultura. Editorial Legasa. 1988.

- Gonzalez Yuste Diversidad Cultural, Comunicación Audiovisual y Nuevas Tecnologías. Un proyecto de educación en comunicación y para la interculturalidad. Universidad Autónoma de Barcelona. Facultad de Ciencias de la Comunicación. Trabajo de Investigación. Dir: Lorite N. 1999.

- Gubern Román. El Eros Electrónico. Taurus Pensamiento. Alfaguara. Madrid. 2000.

- Gubern Román. La Mirada Opulenta. Exploración de la Iconosfera Contemporánea. Ed. Gustavo Gilli. Barcelona. 1987.

- Jameson, Fredric. La estética geopolítica. Paidós. Buenos Aires, 1995.

- Jiménez, José. Imágenes del hombre. Fundamentos de estética, Tecnos, Madrid, 1992 ( $1^{\circ}$ ed., 1986).

- Kusch, Rodolfo. "Anotaciones para una estética de lo americano", en: Revista Comentario, Octubre-Diciembre 1995.

- Landow G.P. Teoría del Hipertexto Ed. Paidós multimedia. Barcelona. 1997.

- Landow, G. P. Hipertexto: la convergencia de la teoría crítica contemporánea y la tecnología. Paidós. Buenos Aires, 1997.

- Lyotard, Jean Francois. La condición posmoderna, Cátedra, Madrid, 1995.

- LLinas F. Maqua J. El cadáver del tiempo. El collage como transmisión narrativo/ideológica. Ed. Fernando Torres. Valencia. 1976. 
- Llorente Bilbao José Ignacio, "Narrativa no lineal e interacción textual" I Congreso Internacional de Comunicación y Realidad. Los impactos de las tecnologías de la información y de la comunicación en las realidades sociales. Publicación Tripodos LenguajePensamiento-Comunicación. Universitat Ramón Llul. Barcelona. 2000.

- Machado, Arlindo. A Arte do Vídeo. Editora Brasiliense. San Pablo, Brasil, 1988.

- Medawar, P. B. , "Is this Scientific Paper a Fraud?" The Listener. 1963

- Metz, Christian. Ensayos sobre la significación en el cine. Ed. Tiempo Contemporáneo. Bs Aires, 1972

- Moreno Isidro. Televisión Digital. ¿Interactiva? Comunicación Audiovisual y Nuevas Tecnologías. Vicente Peña Timón (Coord.) Servicio de Comunicaciones de la Universidad de Málaga. 1998.

- Murray Janet H. Hamlet en la Holocubierta: El Futuro de la narrativa en el Hiperespacio Paidós, multimedia, Digital. Barcelona. 1999.

- Pareyson, Luigi. Estética. Teoría de la formatividad. Sasoni, Firenze. 1974.

- Perez Ornia R. El Arte del video: Introducción a la Historia del Vídeo Experimental. RTVE: Serval. Barcelona.1991.

- Queau, Philippe. Lo virtual, virtudes y vértigos. Paidós. Buenos Aires, 1997.

- Ravera, Rosa María (comp.) Estética y crítica. Los signos del arte, Eudeba, Buenos Aires, 1998.

- Rodriguez León M. A. Universidad, Telemática y Subdesarrollo: La enseñanza superior de comunicación ante las Nuevas Tecnologías en el capitalismo periférico: el caso mexicano. Universidad Complutense de Madrid. Tesis Doctoral. 1996.

- Rush Michael Nuevas Expresiones Artísticas a Finales del Siglo XX. Ed. Destino Thames and Hudson. Barcelona. 2002.

- Sadoul Georges. Dictionnaire des films. Editions du Seuil/Microcosme. Paris. 1965.

- Salt Barry, Film Style and Technology: History and Análisis. Ed. 
Starword. Londres. 1992.

- Sánchez-Biosca, El Montaje Cinematográfico, Paidós Comunicación. Barcelona. 1996.

- Sangro Colón Pedro, Teoría del Montaje Cinematográfico: textos y textualidad, Publicaciones Univ. de Salamanca, 2000.

- Stam Robert, Teorías del Cine, Paidós Comunicación. Barcelona. 2001.

- Tarkovski Andrei Esculpir en el tiempo. Reflexiones sobre el arte, la estética y la poética del Cine. Editorial Rialp, libros de cine. Madrid. 1991.

- Taylor S. J. y Bogdan R. Introducción a los Métodos Cualitativos de Investigación, Ed. Paidós, Barcelona, 1994.

- Tyler Parker, Cine Underground. Historia Critica. Ed. Planeta. Barcelona. 1973.

- Virilio, Paul. El arte del motor. Aceleración y realidad virtual, Manantial, Buenos Aires, 1996 (ed. orig. en francés, 1993).

- Zunzunegui, Santos. Pensar la imagen, Cátedra/ Universidad del País Vasco, Madrid, 1995. 


\section{FUENTES EN INTERNET}

- Arte y Museos

www.numeral.com/everyicon/html

www.diacenter.org

www.media.macm.qc.ca

www.obsolete.com/artwork

www.caiiamind.nsad.newport.ac.uk

www.walkerart.org

www.ica.org.uk

www.asci.org

www.sgg.ch/mullican

www.thecooker.com

www. moma.org

- Ficciones Audiovisuales

www.aulasdesangre.com

www.mahou.es

www.relamido.com

- Materiales audiovisuales anexados

Cirugía (Vesco 1960) (16 mm., blanco y negro)

Sin Título (Khourian 1999) (video vhs, blanco y negro) 
Índice de gráficos

Gráfico 1 - modelo escritor-lector imágenes 15

Gráfico 2 - posicionamiento del observador en la pesquisa

Gráfico 3 - modelo problemático claustro profesores

Gráfico 4 - modelo problemático claustro alumnos 32

Gráfico 5 - forma audiovisual. 41

Gráfico 6 - Secuencia Hiroshima Mon Amour. 69

Gráfico 7 - escenario audiovisual. 70

Gráfico 8 - posproducción lineal/no lineal. 75

Gráfico 9 - posproducción lineal. 77

Gráfico 10 - Mesa virtual de montaje-edición no lineal. 78

Gráfico 11 - textos audiovisuales interactivos. 80

Gráfico 12 - Estructuras hipertextuales. 83

Gráfico 13 - Progresión de recursos usados. 108

Gráfico 14 - Parciales recursos usados. 108

Gráfico 15 - Ej. de Tipología 1- grabación de pantalla y saturación del color. 110

Gráfico 16 - Ej. de Tipología 1- viraje y saturación de color, aplicación de filtros. 110

Gráfico 17 - Ej. de Tipología 3- collage gráfico. 113

Gráfico 18 - Ejemplo de Tipología 3 - pantalla partida-picture in picture. 113

Gráfico 19 - Ejemplo de Tipología 3 - sectorización cromática. 113

Gráfico 20 - Estructura cortometraje Sin Titulo. 118

Gráfico 21 -Imagen y sonido cortometraje Sin Titulo. 119

Gráfico 22 - Estructura cortometraje Cirugía. 121

Gráfico 23 -Comienzo-final cortometraje Cirugía. 121

Gráfico 24 - estructuración a partir de la mirada cortometraje Cirugía. 122

Gráfico 25 - imagen y sonido - cortometraje cirugía. 123 
Gráfico 26 - Televisión - consumo diario.

Gráfico 27 - Televisión - programación de preferencia. $\quad 126$

Gráfico 28 - Cine en sala - Cine en video. 127

Gráfico 29 - Largometrajes ficción - formas de consumo. $\quad 128$

Gráfico 30 - Preferencia Genero Cinematográfico. 129

Gráfico 31 - Informática - Uso._131

Gráfico 32 - Radio - Música e Información. 132

Gráfico 33 - Tendencias Consumo diario de Radio AM-FM. 133

Gráfico 34 - Porcentajes oyentes AM-FM. 133

Gráfico 35 - Esquema Características del lector de imágenes.

Gráfico 36 - Esquema Características del escritor de imágenes. 141

Gráfico 37 - Esquema correspondencias escritor-lector de imágenes. 143

Gráfico 38 - relaciones escritura y lectura/conformación imaginario. $\quad 147$

Gráfico 39 - relaciones escritura y lectura/conformación imaginario/herramientas__ 148

Gráfico 40 - Esquema formas de asociación- producción grupal. 175 
ANEXOS 
Se presentan en este apartado los siguientes materiales:

\section{Anexo metodológico.}

Es una ampliación que informa de los criterios utilizados en la implementación de las encuestas y en el procesamiento y análisis de las mismas.

\section{Anexo encuesta de consumo mediático.}

Se expone el diseño de la encuesta que fue implementada como herramienta para la determinación del perfil de consumidores-lectores audiovisuales de los alumnos observados.

\section{Anexo análisis de ficciones audiovisuales interactivas.}

Se presenta este análisis para fundamentar algunos conceptos de nuestro marco teórico. Tres ficciones audiovisuales de existencia en la web son tipificadas y revisadas sus articulaciones e interactividad.

\section{Anexo análisis de dos modelos audiovisuales.}

Un cd-rom interactivo permite revisar material audiovisual producido por alumnos de la licenciatura de comunicación audiovisual. El análisis expone dos formas distintas de plantear la estructura espacio temporal de un producto audiovisual. 
ANEXO METODOLOGICO 


\section{Particularidades en el análisis de la encuesta}

La simplicidad en el diseño de la encuesta responde a un criterio que contempla la herramienta-encuesta como un primer sondeo ampliado posteriormente mediante entrevistas personales y grupales (equipos realizativos). La encuesta fue el primer conocimiento a nivel individual de los hábitos mediáticos, la conformación de los grupos de trabajo constituyó un espacio de intercambio de realidades a veces muy diferentes que necesariamente debían avanzar en su dinámica grupal hacia una síntesis expresada objetivamente en el cortometraje.

Esto justificó la elección de una forma cualitativa-cuantitativa, con las técnicas de trabajo de campo que se han resumido en el apartado sobre metodología. Algunas de las dificultades que surgieron con la encuesta fueron:

- Se señalaban como preferidos (en televisión) aquellos programas de entretenimiento o ficción, obviando los informativos (se verificó a posteriori en las entrevistas).

- En general la frecuencia (horas por día) no es relacionable con la preferencia, que normalmente es un programa de frecuencia semanal (sobre todo en televisión aire).

En este esquema mixto cuantitativo-cualitativo se optó incluir en las entrevistas los siguientes aspectos:

Hábitos al mirar o al escuchar radio, con amigos, mientras trabajan o estudian. El uso del mando a distancia. (Zaping)

En el estudio se incluye una mirada integradora en los hábitos de ver cine (televisión aire-video-televisión prepaga), se considera eje de análisis el largometraje de ficción reconociendo diferencias en la forma de ver (publicidades intercaladas en la televisión aire, posibilidad de suspender el 
visionado en el cine en videocasete, zaping en el televisión prepaga, retención pasiva absoluta del espectador en la sala cinematográfica).

Se cotejó también en entrevistas el dato de preferencias (film, programa de televisión, etc.) con la pregunta ¿último programa o film visto?

Los efectos de distorsión previstos fueron:

Influencia de la cursada de la materia: El conocimiento por parte del alumno de la filmografía de uso en la cátedra provoca distorsiones. En vez de decir cual es realmente su film preferido, señala (en complacencia con la cátedra) algún material fílmico de uso durante el curso. Por esto las encuestas se completaron en la primera clase.

El estudiante del interior (provincias) no siempre dispone de la infraestructura que tenia en su localidad de origen. Esto modifica fundamentalmente los hábitos de Internet, televisión, cine, etc. Se les aclaró entonces a los encuestados que interesaban los hábitos con los que venía de su pueblo o localidad.

Otro aspecto fundamental a tener en cuenta es que fueron encuestados la totalidad de los alumnos de los cursos analizados (1999-2000). Las entrevistas posteriores implicaron un muestreo sobre este total. El criterio para esto respondió a la necesidad de profundización de casos paradigmáticos. Esta selección surgió de cotejar la forma y organización grupal, y sus características en relación con el proyecto productivo audiovisual.

Asimismo no se cruzaron variables que involucraran el perfil socioeconómico, edad, sexo, etc.: en la elaboración y presentación de los resultados se tuvieron presentes fundamentalmente las hipótesis de trabajo que señalaban como unidad de análisis al grupo realizador. Se recurrió para complementar a un estudio realizado por la Secretaría Académica de la UNLP sobre el alumno ingresante, observándose cierta homogeneidad garantizada obviamente por aquellas condiciones que dicta el ingreso a una carrera universitaria 
determinada, de tal universidad, etc. También fue de crucial importancia el poder resolver la tipificación del grupo lector audiovisual a partir de datos individuales.

\section{El problema de cómo tipificar un grupo lector audiovisual}

El estudio se propone investigar sobre la relación lector-escritor de imágenes y esta relación define como principal objeto a tipificar a un grupo.

Entender a la "objetividad = intersubjetividad, suma de subjetividades" fue la premisa aplicada. Por ejemplo: fue necesario aplicar distintos criterios para tipificar a cada uno de los grupos: como productor de imagen el grupo se define fundamentalmente por el cortometraje realizado, pero como lector: ¿cómo pasamos de los datos individuales (el dato principal que surge de la encuesta) a la tipificación del grupo? La resolución se encontró en los datos que surgieron en las entrevistas con cada grupo (obviamente un grupo que se articula horizontalmente en su funcionamiento es diferenciable de otro que asume roles verticales-industriales). En cada caso podemos señalar a priori distintas

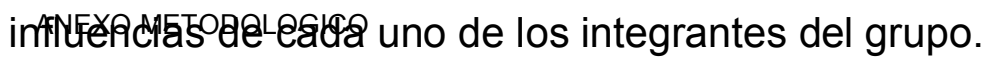

Se observó que en aquellos grupos que se articularon con una participación activa y horizontal en todos los procesos (guión, rodaje-grabación, posproducción), el perfil como lector audiovisual individual de cada integrante tuvo cierta homogeneidad sobre la media del grupo. Asimismo en los grupos que funcionaron más verticalmente se verificaron mayores contrastes en los tipos individuales de consumos mediáticos. Lo anterior se pude resumir según el esquema del gráfico 40 . 


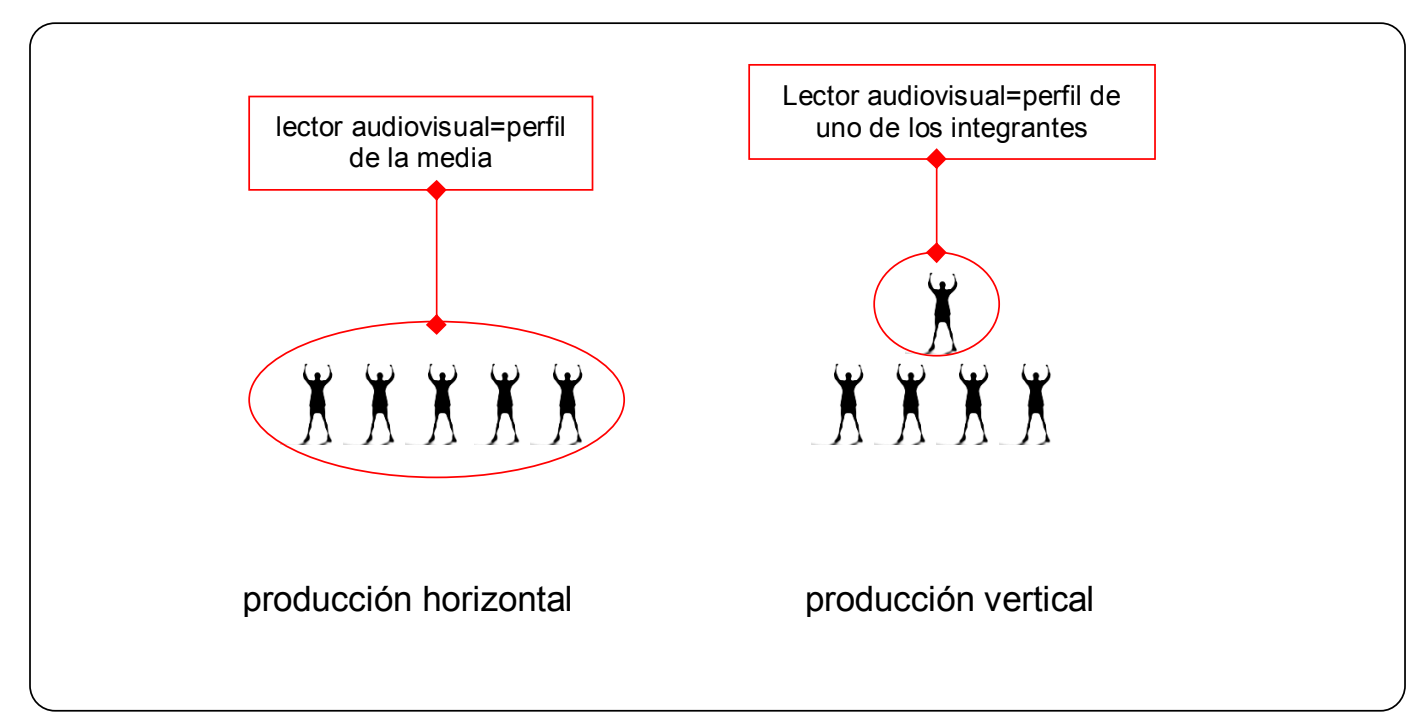

Entendemos que lo anterior es consecuencia directa de la dinámica puesta en juego en la misma autoconformación y autogestión de los grupos. La conformación de los grupos no fue gestionada por la cátedra, o sea que a la hora de formarse cada grupo la identificación a través de los gustos mediáticos fue crucial. Esto mismo de alguna manera marcó radicalmente la organización del trabajo en la producción.

La heterogeneidad en un grupo pidió necesariamente una organización mas jerarquizada, encabezada por aquel que en la dinámica propia del grupo era el responsable estético del proyecto. De más esta decir que generalmente en este tipo de grupo quien escribió el guión fue quien dirigió la producción. La homogeneidad en los gustos mediáticos facilitó dinámicas grupales que tendieron a una organización más horizontal en la producción.

En ambos casos la resolución de pasar de los datos individuales (de lector audiovisual) a la determinación de un tipo grupal no tuvo mayores complicaciones. Tanto en una estructura jerárquica como en una horizontal el mismo grupo decidió en su forma de organizarse quien definía su perfil grupal: la media de los integrantes cuando el grupo se organizó horizontal y las 
características de consumo mediático del alumno cabeza de grupo en los casos de estructuras más verticales. 
ANEXO ENCUESTA

CONSUMO MEDIATICO 
TV

VE TELEVISIÓN DE AIRE ?......... .....CON QUE FRECUENCIA? (horas x día). SEÑALE TRES PROGRAMAS EN ORDEN DE PREFERENCIA

VE TELEVISIÓN DE CABLE? CON QUE FRECUENCIA ? (horas x día). SEÑALE TRES PROGRAMAS O CANALES EN ORDEN DE PREFERENCIA

TIENE EL HABITO DE GRABAR PROGRAMAS ?.....

CONSERVA LA GRABACIÓN DESPUÉS DE VISTA ?.

\section{RADIO}

ESCUCHA FM ? CON QUE FRECUENCIA ? (horas x día)..

MÚSICA ?

INFORMACIÓN ?

OTRO ?

ESCUCHA AM?..............CON QUE FRECUENCIA ? (horas x día).............

MÚSICA ?

INFORMACIÓN?

OTRO ?

CINE

ASISTE A SALAS COMERCIALES ? CON QUE FRECUENCIA ?.

ASISTIÓ A CICLOS ?.

ASISTIÓ A FESTIVALES ? ....

VE CINE POR TV DE AIRE ?.

CON QUE FRECUENCIA ?

VE CINE POR TV CABLE?

CON QUE FRECUENCIA ?

VE CINE POR VIDEO? CON QUE FRECUENCIA ?

GÉNERO CINEMATOGRÁFICO PREFERIDO.

POSEE UNA VIDEOTECA PERSONAL ?

TRES PELÍCULAS PREFERIDAS

\section{INFORMÁTICA}

POSEE Y/O USA HABITUALMENTE COMPUTADORA ?

HERRAMIENTA DE TRABAJO O ESPARCIMIENTO.

USA PROCESADOR DE TEXTO ?.

USA PROCESADORES DE IMAGEN (VIDEO, FOTO, SONIDO ETC)

USA INTERNET...

JUEGOS

OTROS.

CON QUE FRECUENCIA 
GRAFICA

QUE LEE? ..............................................

FRECUENCIA......................................

TRES (LIBROS, REVISTAS O DIARIOS DE SU PREFERENCIA)..

ARTES ESCÉNICAS (TEATRO, DANZA) Y ARTES PLÁSTICAS

ASISTE A EXPOSICIONES O ESCENARIOS?.

CON QUE FRECUENCIA?. 